\title{
The Lithic and Ceramic Artifacts from the Spradley Site (41NA206), Nacogdoches County, Texas
}

Timothy K. Perttula

Heritage Research Center, Stephen F. Austin State University

Paul Marceaux

Center for Archaeological Research, The University of Texas at San Antonio

Follow this and additional works at: https://scholarworks.sfasu.edu/ita

Part of the American Material Culture Commons, Archaeological Anthropology Commons, Environmental Studies Commons, Other American Studies Commons, Other Arts and Humanities Commons, Other History of Art, Architecture, and Archaeology Commons, and the United States History Commons

Tell us how this article helped you.

This Article is brought to you for free and open access by the Center for Regional Heritage Research at SFA ScholarWorks. It has been accepted for inclusion in Index of Texas Archaeology: Open Access Gray Literature from the Lone Star State by an authorized editor of SFA ScholarWorks. For more information, please contact cdsscholarworks@sfasu.edu. 


\section{The Lithic and Ceramic Artifacts from the Spradley Site (41NA206), Nacogdoches County, Texas}

\section{Creative Commons License}

(c) (1) (8)

This work is licensed under a Creative Commons Attribution-NonCommercial 4.0 International License 


\section{The Lithic and Ceramic Artifacts from the Spradley Site (41NA206), Nacogdoches County, Texas}

\section{Timothy K. Perttula and Paul Marceaux}

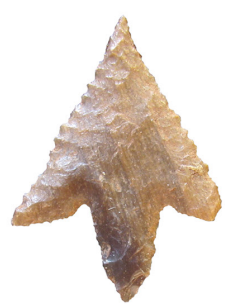

a

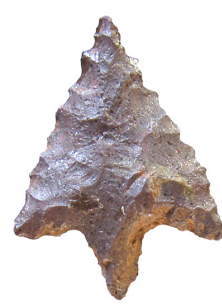

b

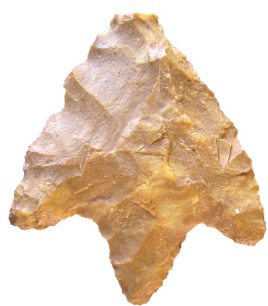

c

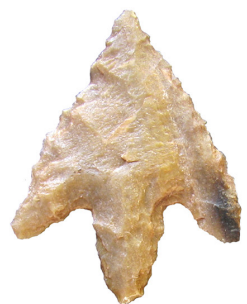

d
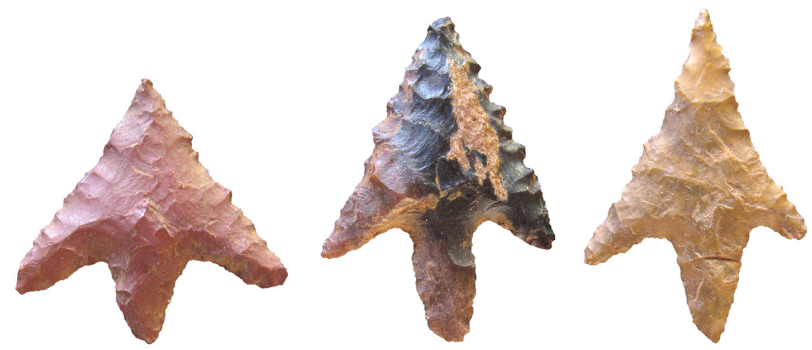

e

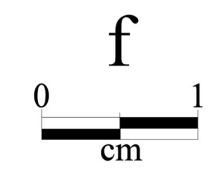

g

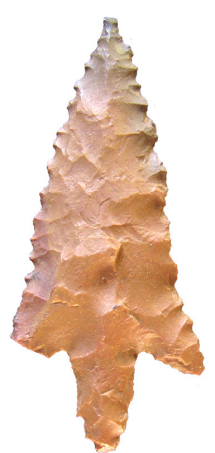

$\mathrm{h}$

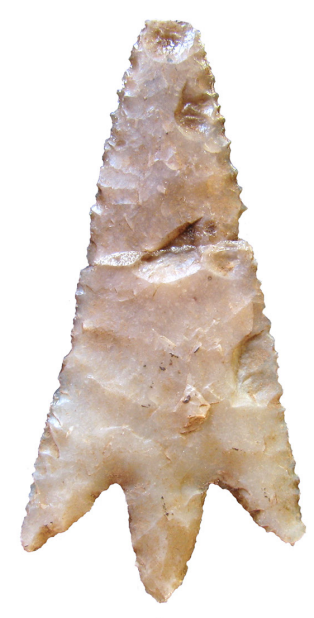

i

Special Publication No. 50

Friends of Northeast Texas Archaeology 


\section{Editor, Timothy K. Perttula 10101 Woodhaven Dr. Austin, Texas 78753 tkp4747@aol.com}

\section{Distribution, Bo Nelson, 344 CR 4154 \\ Pittsburg, Texas 75686 \\ RBoNelson@aol.com}

\section{Cover art:}

Perdiz arrow points from the Spradley site

Copyright 2018, Friends of Northeast Texas Archaeology

Pittsburg and Austin 


\section{Table of Contents}

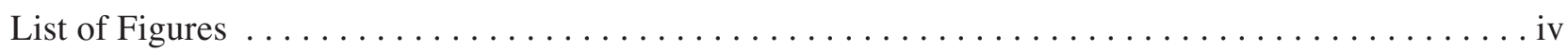

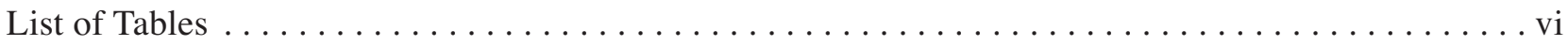

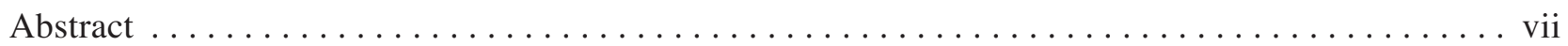

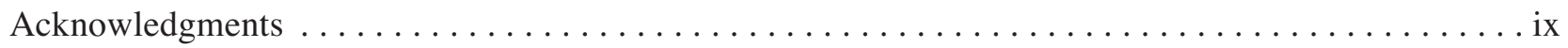

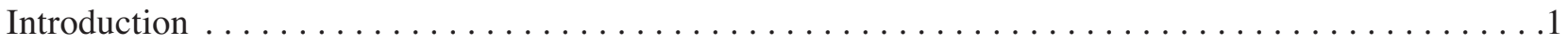

Chipped and Ground Stone Tools $\ldots \ldots \ldots \ldots \ldots \ldots \ldots \ldots \ldots \ldots \ldots \ldots \ldots \ldots \ldots \ldots \ldots \ldots$

Chipped Stone Tools . . . . . . . . . . . . . . . . . . . . . . . . . . . . . .44

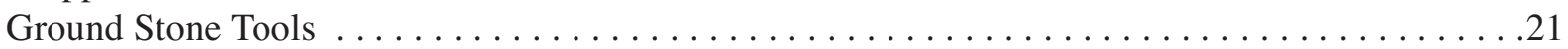

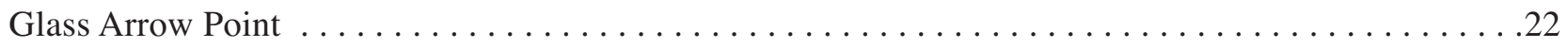

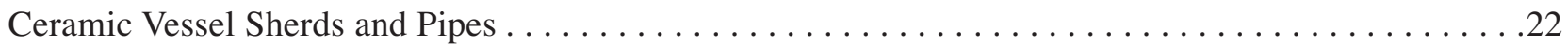

Ancestral Caddo Ceramic Artifacts. . . . . . . . . . . . . . . . . . . . . . 22

Ceramic Comparisons between certain Historic Caddo Sites in Nacogdoches County, Texas:

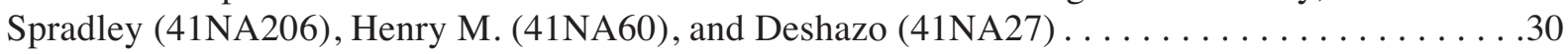

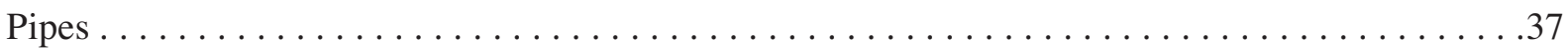

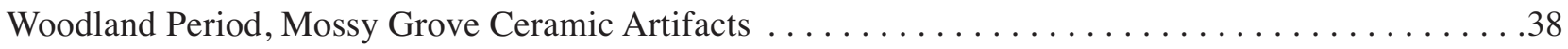

Summary and Synthesis of the Archaeological Findings from the Spradley Site . . . . . . . . . . 39

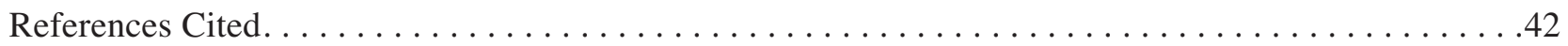




\section{List of Figures}

Figure 1. Location of the Spradley site in the East Texas Pineywoods. . . . . . . . . . . . .

Figure 2. The Spradley site (41NA206) and other Historic Caddo sites in the general vicinity. Figure

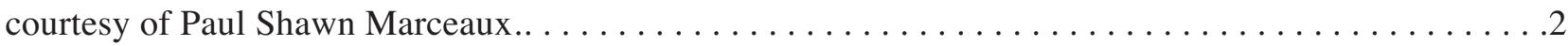

Figure 3. Spradley site: a, excavation areas; Map provided courtesy of Victor Galan; b, overview of the

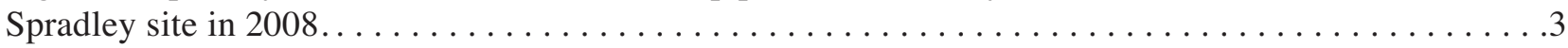

Figure 4 . Scraping tool from the Spradley site $(\mathrm{N} 61-W 47,1 v .4) \ldots \ldots \ldots \ldots \ldots \ldots \ldots \ldots \ldots$

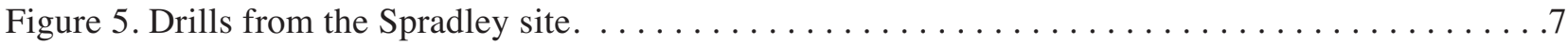

Figure 6. Bifaces from the Spradley site: a, N64-W57, lv. 3; b, N76-W65, 1v. 4; c, N83-W47, 1v. 3 .. . . .8

Figure 7. Selected dart points in the Spradley site chipped stone tool assemblage . . . . . . . . . 10

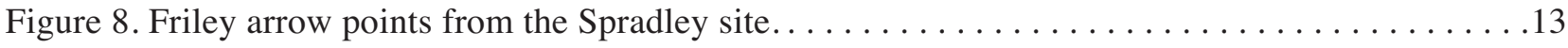

Figure 9. Scallorn, Colbert, and Alba arrow points from the Spradley site . . . . . . . . . . . 14

Figure 10. Bonham arrow points from the Spradley site $\ldots \ldots \ldots \ldots \ldots \ldots \ldots \ldots \ldots \ldots \ldots \ldots \ldots \ldots \ldots$

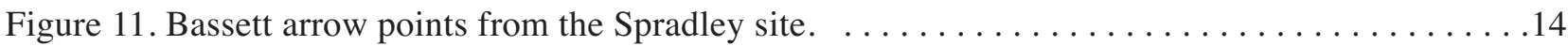

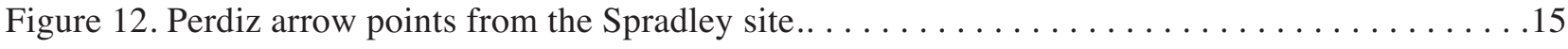

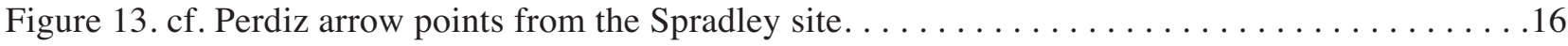

Figure 14. cf. Turney arrow points from the Spradley site. $\ldots \ldots \ldots \ldots \ldots \ldots \ldots \ldots \ldots \ldots \ldots \ldots \ldots$

Figure 15 . Cuney arrow point from the Spradley site $\ldots \ldots \ldots \ldots \ldots \ldots \ldots \ldots \ldots \ldots \ldots \ldots \ldots \ldots$

Figure 16. Arrow point fragment from the Spradley site made from a bluish-green glass... . . . . . . 17

Figure 17. Social networks of northern and southern Historic Caddo groups in East Texas. Figure

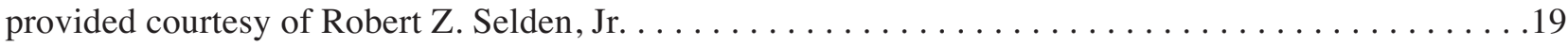

Figure 18. Unidentified arrow point from N80-W51, level 2 at the Spradley site. . . . . . . . . 19

Figure 19. Arrow point preforms from the Spradley site $\ldots \ldots \ldots \ldots \ldots \ldots \ldots \ldots \ldots \ldots \ldots \ldots \ldots \ldots \ldots$

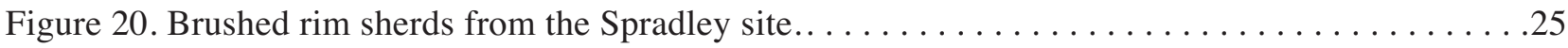




\section{List of Figures, cont.}

Figure 21. Spradley Brushed-Incised body sherds from the Spradley site . . . . . . . . . . . .25

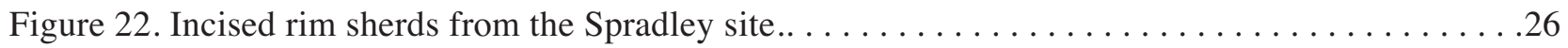

Figure 23. Sherds with incised-punctated decorative elements from the Spradley site . . . . . . .26

Figure 24 . Range of punctated rim and body sherds from the Spradley site $\ldots \ldots \ldots \ldots \ldots \ldots \ldots .27$

Figure 25 . Patton Engraved body sherds from the Spradley site $\ldots \ldots \ldots \ldots \ldots \ldots \ldots \ldots \ldots \ldots$

Figure 26. Patton Engraved and Hume Engraved sherds from the Spradley site: a, c-d, Patton

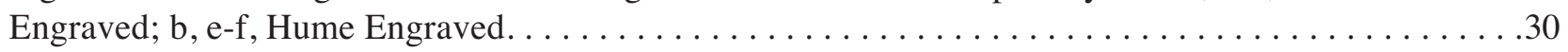

Figure 27. Location of Group I to Group V Historic Caddo ceramic assemblages in Nacogdoches

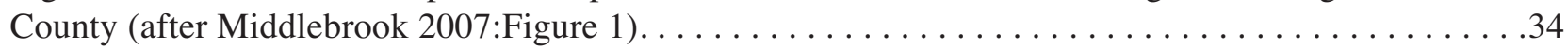

Figure 28. Spatial groupings of Historic Caddo and Historic Ais ceramic clusters I-IX

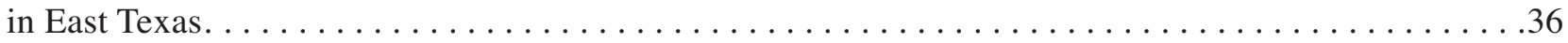

Figure 29. Punctated elbow pipe sherd from the Spradley site. . . . . . . . . . . . . . . 37 


\section{List of Tables}

Table 1. Depth of arrow points, arrow point preforms, and dart points at the Spradley site. .4

Table 2. Flake tools from the Spradley site .5

Table 3. Scrapers from the Spradley site. 5

Table 4. Drills from the Spradley site.

Table 5. Bifaces from the Spradley site. .7

Table 6. Dart points from the Spradley site. .8

Table 7. Arrow points from the Spradley site.

Table 8. Distribution of arrow point forms on selected Historic Caddo sites in East Texas and Southwest Arkansas.

Table 9. Arrow point preforms from the Spradley site. .20

Table 10. Ground stone tools from the Spradley site. .21

Table 11. Ceramic wares at the Spradley site. 22

Table 12. Temper use in a detailed sherd analysis sample from the Spradley site.

Table 13. Utility ware decorative classes from the Spradley site. 24

Table 14. Patton Engraved decorative elements on sherds from the Spradley site .28

Table 15. Decorative classes in the utility ware and fine ware ceramics. .29

Table 16. Temper comparisons between the three Historic Caddo sites.

Table 17. Ceramic comparisons with selected other Historic Caddo sites in Nacogdoches County, Texas. 32

Table 18. Groups I-V of Historic Caddo Ceramic Assemblages. .33

Table 19. Comparisons between East Texas Historic Caddo assemblages 35

Table 20. Sandy paste ceramic sherds from the Spradley site. 38 


\begin{abstract}
The Spradley site (41NA206) is a Native American archaeological site in the Bayou La Nana valley in Nacogdoches County in the East Texas Pineywoods. Bayou La Nana is a southward-flowing tributary to the Angelina River. The site is best known for its late $17^{\text {th }}$-early $18^{\text {th }}$ century Historic Caddo period occupation, and the recovery of a number of European trade goods from habitation deposits, but the site was also occupied in Late Archaic (ca. 5000-2500 years B.P.), Woodland (ca. 2500-1150 years B.P.), and pre-A.D. 1400 Caddo periods. The Spradley site was the scene of Stephen F. Austin State University (SFASU) Field School in 2001, 2003, and 2005. This publication presents the first comprehensive and detailed publication of both the lithic and ceramic artifacts recovered from the SFASU work at the Spradley site.
\end{abstract}

The chipped stone tools from the Spradley site are dominated by arrow points and arrow point fragments $(n=70)$ and arrow point preforms $(n=12)$. Also present are flake tools $(n=9)$, scrapers $(n=3)$, drills $(n=3)$, bifaces $(n=6)$, and dart points $(n=23)$. The identified arrow point and dart point types in the Spradley site assemblage indicate that it was used during Late Archaic (from ca. 2000 B.C.), Woodland, and pre-A.D. 1400 Caddo periods, as well as during the post-A.D. 1680 Historic Caddo period. All of the dart points and dart point fragments are made from local lithic raw materials, almost exclusively from petrified wood. Five different dart point types are present in the sample, including Gary $(n=6)$, Kent ( $n=7)$, Godley $(n=1)$, Pontchartrain $(n=2)$, and Yarbrough $(n=)$; the Pontchartrain and Yarbrough dart points are of Late Archaic manufacture (ca. 5000-2500 years B.P.). The Gary, Godley, and Kent dart points are temporal diagnostics of the Woodland period (ca. 2500-1150 years B.P.) in this part of the Pineywoods.

Most of the arrow points are made on local lithic raw materials (83 percent) - among them petrified wood, quartzite, and local earth-toned cherts - but 17 percent are made on non-local cherts. One arrow point fragment is made from a bluish-green glass. The oldest arrow point styles in the arrow point assemblage include Friley $(\mathrm{n}=5)$ and Scallorn $(\mathrm{n}=1)$ points, likely manufactured during late Woodland period times (ca. A.D. 700-900). These are followed by ca. A.D. 900-1200 arrow point styles: Alba (n=1) and Colbert $(n=2)$. There are two ca. A.D. 1200-1400 Bonham arrow points in the assemblage. A Late Caddo arrow point type in the assemblage is the Bassett point $(n=3)$. The majority of the arrow points are associated with the principal Caddo occupation, one dating to early Historic period times. This includes 23 Perdiz points, cf. Perdiz points $(n=8)$, cf. Turney $(n=4)$, and a single Cuney point. One bluish-green glass arrow point fragment also is part of this component

There are 40 body sherds from sandy paste Goose Creek Plain, var. unspecified vessels in the assemblage from the Spradley site. These are part of the Woodland period Mossy Grove culture occupation of the site that occurred sometime between ca. 500 B.C.-A.D. 800. The sherds are from vessels made with a non-tempered and locally available sandy clay.

The remaining 8806 sherds from the Spradley site excavations are from plain wares, utility wares, and fine ware vessels. The plain wares comprise 52 percent of the collection. Sherds from utility ware vessels account for 37 percent of the assemblage, and fine wares only account for 10.5 percent of the sherds from the site. The assemblage has a plain/decorated sherd ratio of 1.12, a brushed to plain sherd ratio of 0.51 , and a brushed to other wet paste sherd ratio of 2.68. Brushed marks are present on 56.6 percent of the decorated sherds $(n=4156)$.

Sherds that compare favorably to a number of types that occur on other Neches-Angelina River basin ancestral Caddo sites of late Frankston phase age (ca. A.D. 1560-1680), or date to the early part of the 
Allen phase (ca. A.D. 1680-1720), are identified in the Spradley site assemblage. They include Hume Engraved, Keno Trailed, Killough Pinched, King Engraved, La Rue Neck Banded, Lindsey Grooved, Maydelle Incised, Patton Engraved, Poynor Engraved, and Spradley Brushed-Incised. Sherds from Patton Engraved and Spradley Brushed-Incised, both Allen phase types, are most common in the Spradley site assemblage.

The ceramic sherds are from vessels tempered primarily with grog or burned bone. Grog occurs in 56 percent of the sherds, while bone temper is present in 35 percent of the sherds. Crushed hematite is present in 7 percent of the sherd sample. Vessels made with shell temper ( 0.7 percent of the sherds) are from non-locally produced wares, likely made by Caddo groups along the Red River to the northeast in Northwest Louisiana and Southwest Arkansas.

There are a number of decorative classes in the utility wares. Sherds with brushed marks dominate these wares, accounting for 71 percent of the utility wares. A number of the brushed-incised sherds are from Spradley Brushed-Incised vessels that have parallel brushing with overlapping straight incised lines opposed or perpendicular to the brushing. Patton Engraved is the dominant fine ware type at the Spradley site. The frequency of curvilinear, horizontal, and parallel engraved lines with tick marks suggests that var. Freeman, var. Allen, and var. Fair of Patton Engraved are present in the Spradley site fine wares. Patton Engraved, var. Freeman is the earliest of the varieties, likely dating to the late $17^{\text {th }}$ century, while var. Allen is a slightly later Patton Engraved variety, perhaps dating from the early $18^{\text {th }}$ century.

In comparison with other contemporaneous Allen phase sites in Nacogdoches County, where ceramics are primarily grog-tempered, bone-tempered pottery is much more abundant at the Spradley site, suggesting the existence there of a different tradition of ceramic technology and manufacture there. The closest ceramic comparisons between the Spradley site and other known Nacogdoches County historic Caddo sites is with 41NA223, also on Bayou Lanana. There are distinct spatial groupings of Allen phase sites in Nacogdoches County, including Group I on Bayou La Nana (including the Spradley site). Most ceramic groups represent the core of known Hasinai Caddo ceramic assemblages in the Angelina River basin, or are linked with the Nasoni Caddo and Mission Nasoni (1716-1730). The Spradley site occupation is most closely affiliated with the Nacogdoche Caddo, and these defined ceramic group represent different but clearly related and interacting social groups or communities of Caddo peoples living in the Angelina River basin in historic times.

Further archaeological research concerning the Spradley site excavations remains to be completed. This includes the reporting of the excavations themselves, along with the presentation of the identified features documented in the work. Still to be completed is the analysis of the recovered lithic debris at the Spradley site, the plant and animal remains found in the archaeological deposits, and a full accounting and analysis of the $18^{\text {th }}$ century European artifacts found at the site. 


\section{Acknowledgments}

We first want to thank the many students that attended the 2001, 2003, and 2005 Stephen F. Austin State University (SFASU) Field Schools, and worked hard, and we acknowledge the planning by the late Dr. James E. Corbin in initiating the field schools at the Spradley site. George Avery, SFASU Curator of Collections, provided access to the collections for this research project.

Sandra Hannum, Paul Shawn Marceaux, Tom Middlebrook, Robert Z. Selden, Jr., and Lance Trask each prepared figures for the report. 



\section{Introduction}

The Spradley site (41NA206) is an important Native American archaeological site in the Bayou La Nana valley in Nacogdoches County in the East Texas Pineywoods (Figure 1). Bayou La Nana is a southward-flowing tributary to the Angelina River and merges with it about $15 \mathrm{~km}$ below the city of Nacogdoches, Texas. The Spradley site itself lies about $5 \mathrm{~km}$ south of the city.

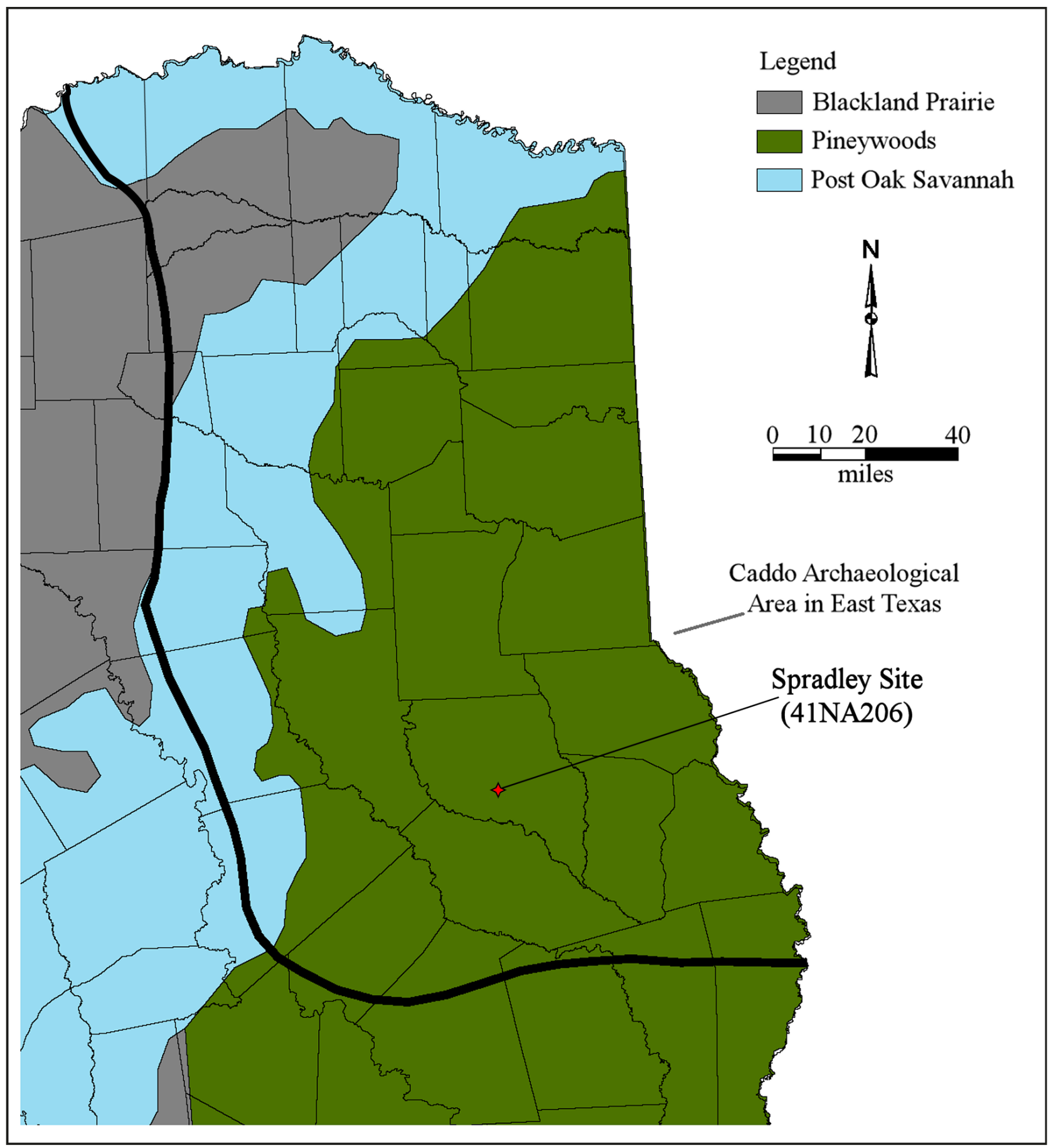

Figure 1. Location of the Spradley site in the East Texas Pineywoods. 
The site is best known for its late $17^{\text {th }}$-early $18^{\text {th }}$ century Historic Caddo period occupation, and the recovery of a number of European trade goods (Marceaux 2011:114,361) from habitation deposits, but the site was also occupied in Late Archaic (ca. 5000-2500 years B.P.), Woodland (ca. 2500-1150 years B.P.), and pre-A.D. 1400 Caddo periods. There are a number of other known Historic Caddo period settlements in Nacogdoches County, but most of these lie west and northwest of the Spradley site on other tributaries to the Angelina River (Figure 2).

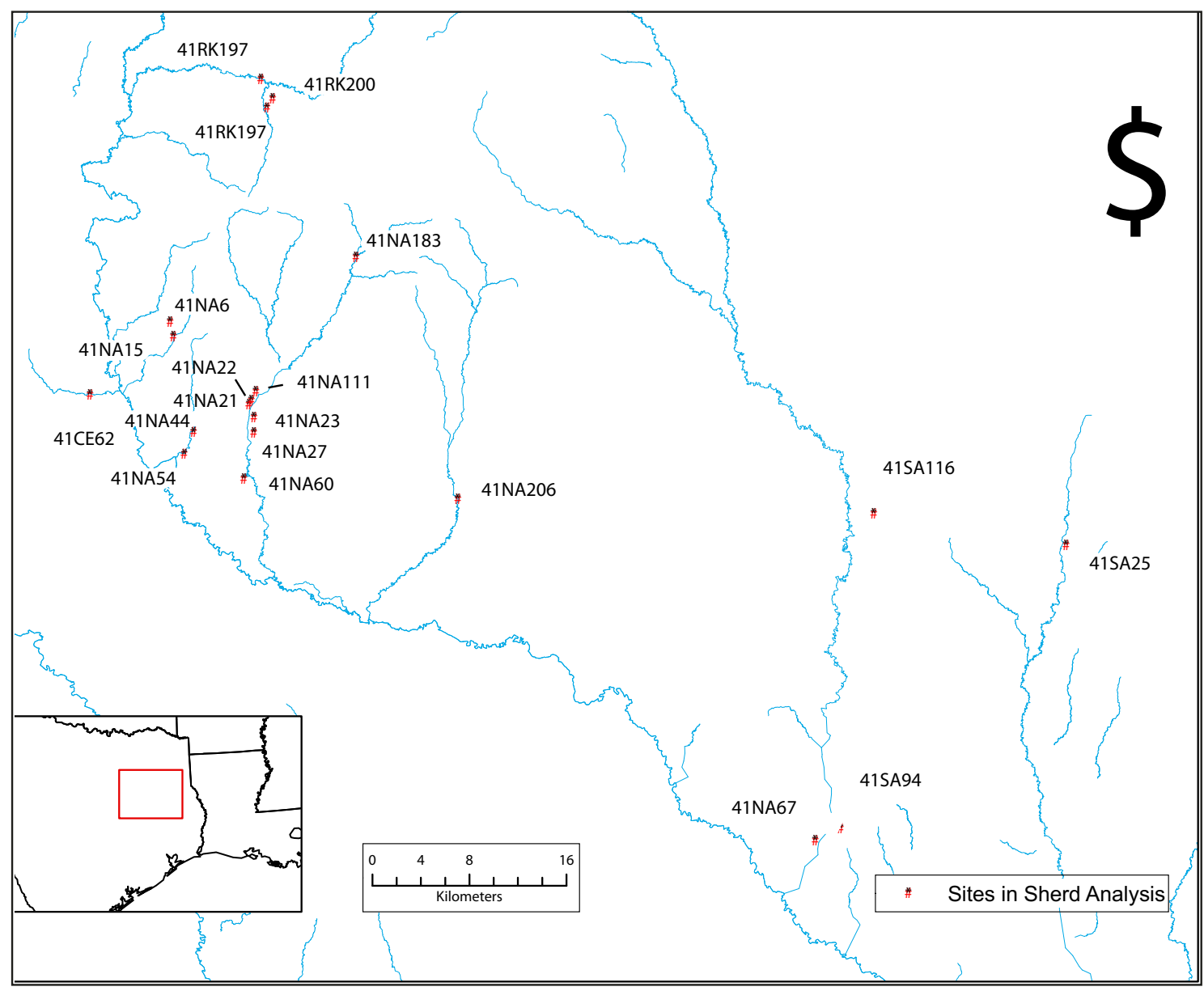

Figure 2. The Spradley site (41NA206) and other Historic Caddo sites in the general vicinity. Figure courtesy of Paul Shawn Marceaux.

The site was found and first investigated by Tom Middlebrook in 1998. This work consisted of four shovel tests, two auger holes, and two rounds of surface collections. Based on its archaeological potential, Dr. James E. Corbin led a Stephen F. Austin State University Field School there in 2001, and further Field Schools by Stephen F. Austin State University under the direction of Victor Galan took place at the Spradley site in 2003 and 2005. Excavations were concentrated in the northwestern and southeastern portions of the known site boundaries (Figure 3a); in 2008, the site area was in pasture (Figure 3b).

There have been a few presentations about the work and findings from the Spradley site given at professional conferences over the years. However, only now in this article will a comprehensive and detailed publication of the lithic and ceramic artifacts recovered in the work at the Spradley site be presented. 


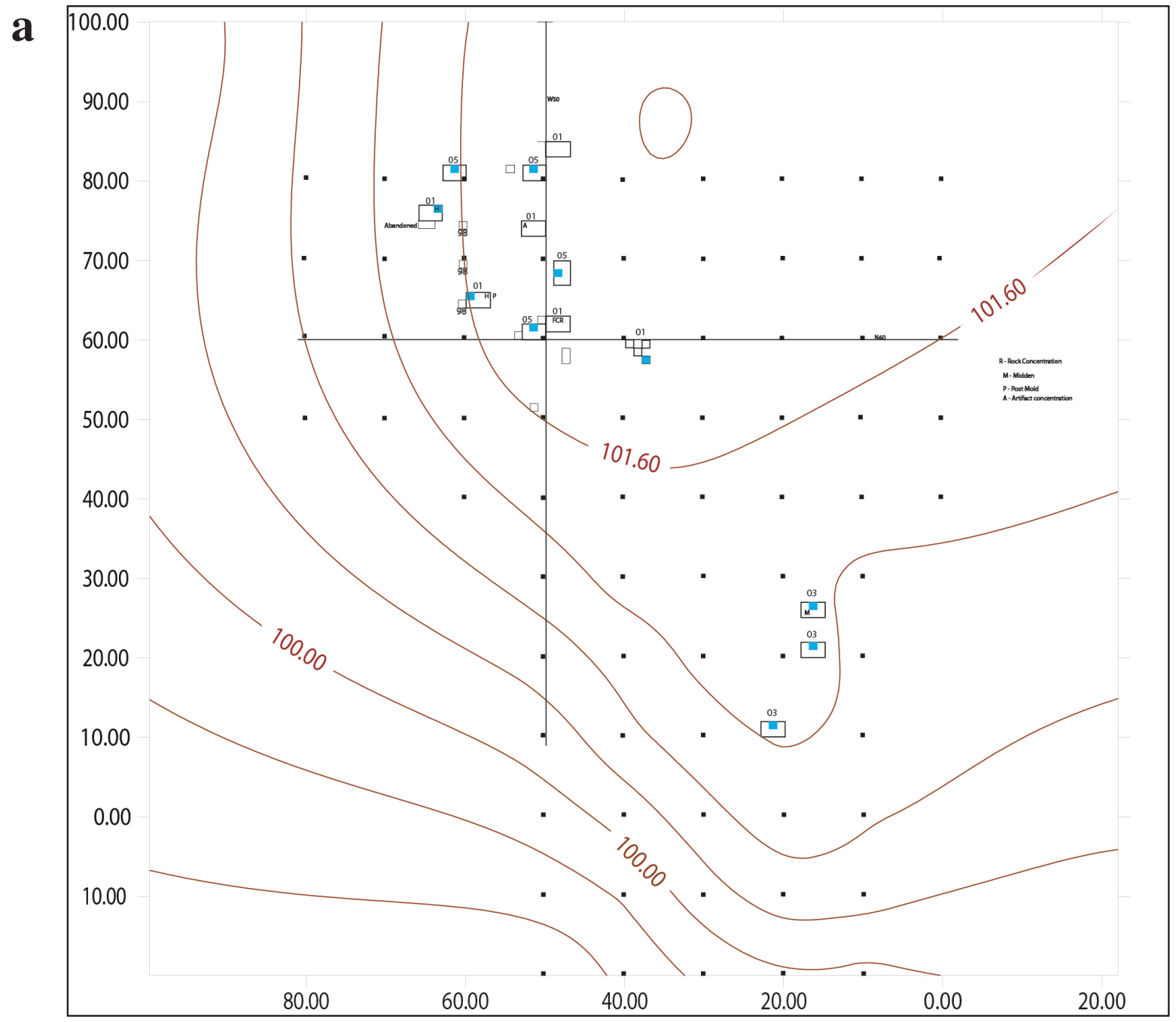

b

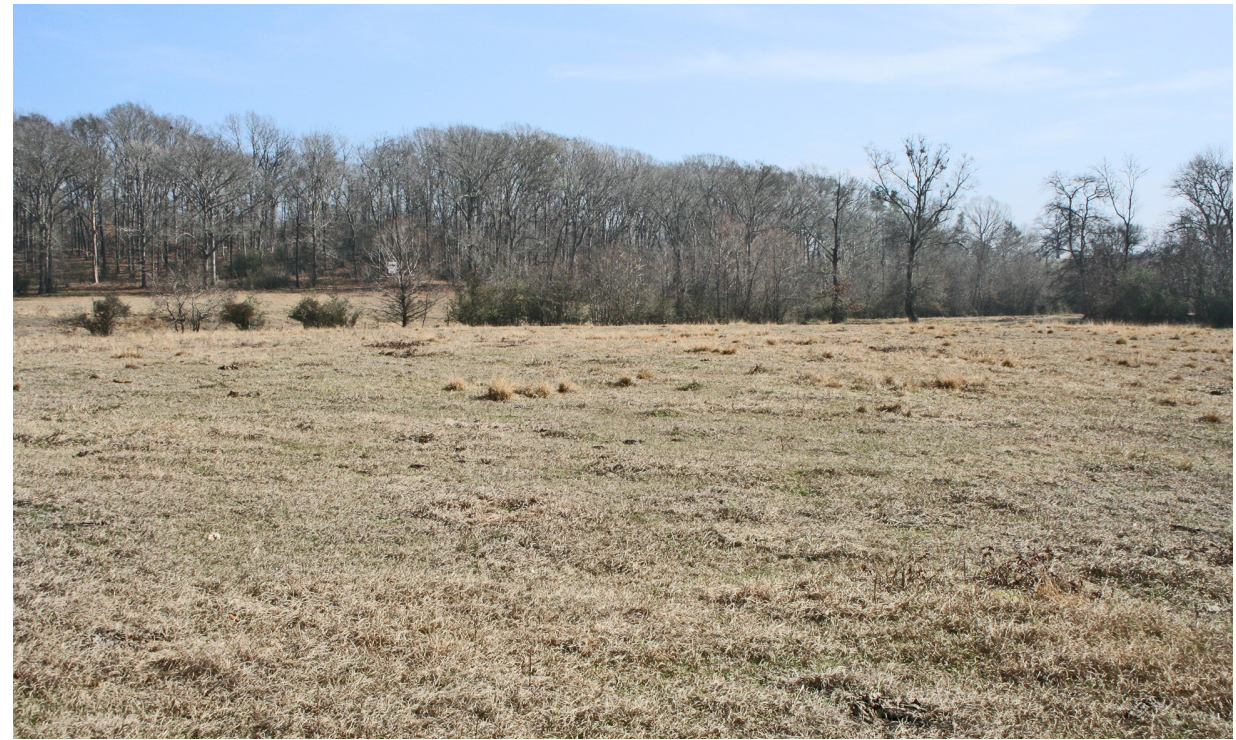

Figure 3. Spradley site: a, excavation areas; Map provided courtesy of Victor Galan; b, overview of the Spradley site in 2008. 


\section{Chipped and Ground Stone Tools, by Timothy K. Perttula}

Lithic tools and the debris from lithic tool manufacture are relatively abundant in the archaeological deposits at the Spradley site, particularly micro-flakes from tool finishing, serration, and resharpening recovered in fine screening. The tool assemblage includes 126 chipped stone tools and 12 ground stone tools.

\section{Chipped Stone Tools}

The chipped stone tools are dominated by arrow points and arrow point fragments $(n=70)$ and arrow point preforms $(n=12)$, as these comprise 75 percent of the tool assemblage. Also present are flake tools $(n=9)$, scrapers $(n=3)$, drills $(n=3)$, bifaces $(n=6)$, and dart points $(n=23)$. The identified arrow point and dart point types in the Spradley site assemblage indicate that it was used during Late Archaic, Woodland, and pre-A.D. 1400 Caddo periods, as well as during the post-A.D. 1680 Historic Caddo period.

Both arrow points, arrow point preforms, and dart points occur in archaeological deposits in both the northwestern and southeastern parts of the site, and from similar depths (Table 1), although not in identical proportions by depth. Arrow points are most abundant from $0-20 \mathrm{~cm}$ bs $(72.8$ percent), from $20-30 \mathrm{~cm}$ bs for arrow point preforms (66.6 percent), and $20-30 \mathrm{~cm}$ bs (39.1 percent) for dart points. The overlapping spatial and vertical distributions of projectile points ranging in age from ca. 2000 B.C. to post-A.D. 1680 in the deposits at the Spradley site indicate that the landform has been a stable surface for thousands of years, and the artifacts that accumulated on its surface represent a palimpsest of occupation and use over a considerable span of time by Caddo peoples and their prehistoric ancestors.

Table 1. Depth of arrow points, arrow point preforms, and dart points at the Spradley site.

\begin{tabular}{|c|c|c|c|c|c|c|}
\hline \multirow[t]{2}{*}{ Level } & \multicolumn{2}{|c|}{ Arrow point } & \multicolumn{2}{|c|}{ Arrow point preform } & \multicolumn{2}{|c|}{ Dart point } \\
\hline & No. & $\%$ & No. & $\%$ & No. & $\%$ \\
\hline 1 & 22 & 31.4 & 2 & 16.7 & 4 & 17.4 \\
\hline 2 & 29 & 41.4 & 5 & 41.6 & 4 & 17.4 \\
\hline 3 & 14 & 20.0 & 3 & 25.0 & 9 & 39.1 \\
\hline 4 & 2 & 2.9 & 1 & 8.3 & 3 & 13.0 \\
\hline 5 & 1 & 1.4 & 1 & 8.3 & 2 & 8.7 \\
\hline 6 & 2 & 2.9 & - & - & 1 & 4.3 \\
\hline Totals & 70 & 100.0 & 12 & 100.0 & 23 & 100.0 \\
\hline
\end{tabular}

\section{Flake Tools}

Expedient flake tools are present only in the northwestern part of the excavated areas at the Spradley site, between N57-N73 and W30-W60. They are also concentrated in levels 1 and 2(0-20 cm bs) (Table 2). 
Table 2. Flake tools from the Spradley site.

\begin{tabular}{|c|c|c|}
\hline Provenience & Raw Material & Description \\
\hline N73-W50, lv. 2 & yellow chert & $\begin{array}{l}\text { non-cortical; bilateral working edges: } \\
10.0+\mathrm{mm}, 11.0+\mathrm{mm}\end{array}$ \\
\hline N72-W52, wall & translucent gray chert & non-cortical; unilateral working edge: $14.0+\mathrm{mm}$ \\
\hline N70-W60, lv. 2 & translucent gray chert & bilateral working edges: $8.2 \mathrm{~mm}$ and $14.0 \mathrm{~mm}$ \\
\hline N69-W48, lv. 1 & gray chert & cortical; bilateral working edges: $9.0 \mathrm{~mm}$ and $15.8 \mathrm{~mm}$ \\
\hline N64-W59, lv. 1 & $\begin{array}{l}\text { translucent grayish-brown } \\
\text { chert }\end{array}$ & non-cortical; unilateral working edge: $20.0 \mathrm{~mm}$ \\
\hline N60-W50, lv. 2 & brownish-red chert & cortical; unilateral working edge: $5.6 \mathrm{~mm}$ \\
\hline N60-W50, lv. 2 & gray chert & non-cortical; unilateral working edge: $9.9 \mathrm{~mm}$ \\
\hline N60-W30, lv. 2 & petrified wood & unilateral working edge: $7.6 \mathrm{~mm}$ \\
\hline N57-W47, lv. 1 & brown chert & cortical; unilateral working edge: $5.6 \mathrm{~mm}$ \\
\hline
\end{tabular}

The flake tools have either unilateral $(n=6)$ or bilateral $(n=3)$ working edges, with micro-edge flaking from tool use. Such tools were likely used in the processing of smaller amounts of resources, including both plant and faunal remains. More than 55 percent of the flake tools-including 67 percent of the bilateral flake tools and 50 percent of the unilateral flake tools (see Table 2) - are on flakes of non-local cherts, probably from Central Texas sources (see Girard 1995:66, 70; Perttula et al. 2010:Table 16).

\section{Scrapers}

Three flake scrapers are in the lithic tool assemblage from the Spradley site. They are from the northwestern part of the investigated area at the site (Table 3). The large end scraper is on hematite, a local lithic raw material, and it has a broad and unifacial scraping edge. The other two scrapers are on flakes of non-local gray and translucent gray chert, with working edges that range from $20.0-49.0 \mathrm{~mm}$ in extent (Figure 4).

Table 3. Scrapers from the Spradley site.

\begin{tabular}{|c|c|c|}
\hline Provenience & Raw Material & Description \\
\hline N73-W51, lv. 1 & translucent gray chert & bifacial side scraper, $20.0 \mathrm{~mm}$ working edge \\
\hline N64-W47, lv. 1 & hematite & unifacial end scraper; $36.0 \mathrm{~mm}$ working edge \\
\hline N61-W47, lv. 4 & $\begin{array}{l}\text { gray chert } \\
\text { edges: } 49.0 \mathrm{~mm}\end{array}$ & unifacial end and side scraper; non-cortical; working \\
\hline
\end{tabular}

The low proportion of scarping tools suggests that the butchering and processing of large game animals was not an important activity during the various occupations at Spradley, unlike other Historic Caddo Allen phase sites (Perttula et al. 2010:39). The generally small size of the scrapers suggests that the focus of Caddo butchering and processing activities was on medium-sized prey that was being hunted, principally deer. 


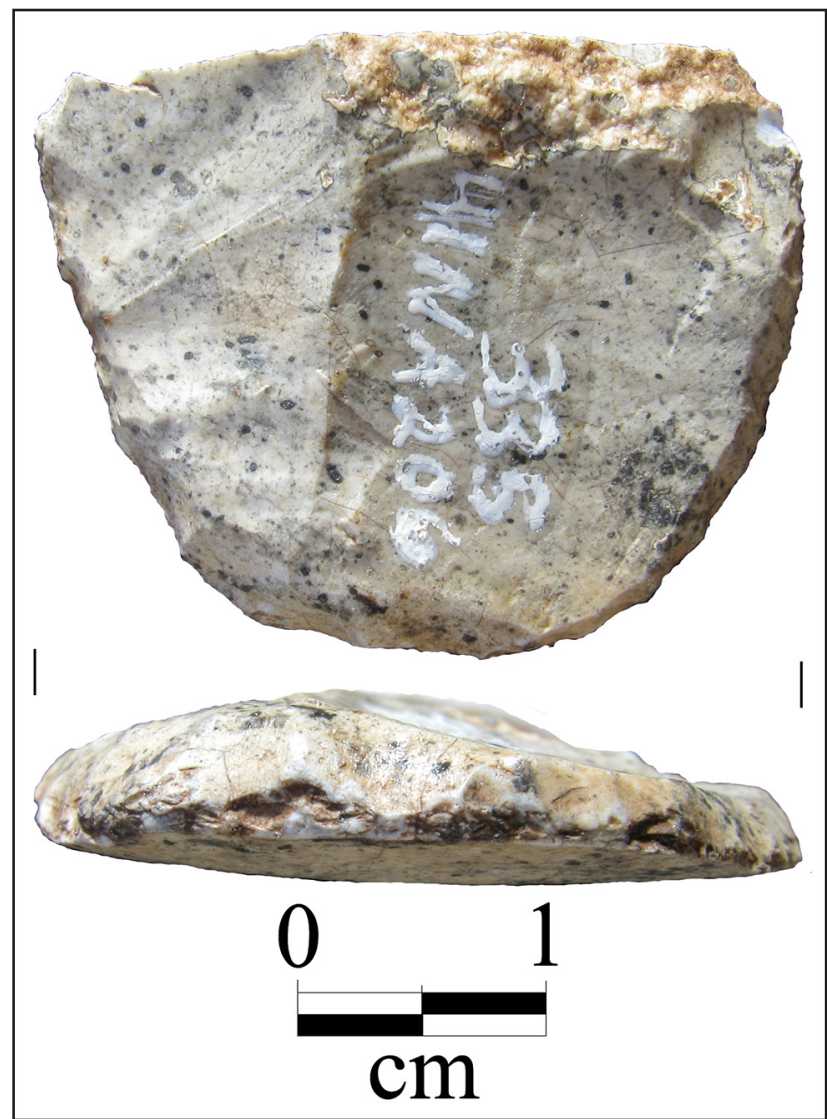

Figure 4. Scraping tool from the Spradley site (N61-W47, lv. 4).

\section{Drills}

The three flake drills were also recovered from archaeological deposits in the northwestern part of the investigated area at the Spradley site (Table 4). Two of the drills are on flake bases, and they have unifacial bits that range from 10.1-13 mm in width; they are on either local or non-local lithic raw materials (Figure 5). The one bifacial drill bit is on a non-local gray chert. The drill bits have evidence of edge crushing/blunting and use-wear on and near the unifacially or bifacially chipped tip.

Table 4. Drills from the Spradley site.

\begin{tabular}{lll}
\hline Provenience & Raw Material & Description \\
\hline N80-W40, lv. 2 & petrified wood & unifacial bit width: $10.1 \mathrm{~mm}$ \\
N73-W50, lv. 2 & gray chert & $\begin{array}{l}\text { unifacial drill bit on flake base; length, } 22 \mathrm{~mm}, \\
\text { width, } 13 \mathrm{~mm} \text {, thickness, } 5 \mathrm{~mm} \\
\text { bifacial bit fragment, } 3.7 \mathrm{~mm} \text { thick }\end{array}$ \\
\hline
\end{tabular}




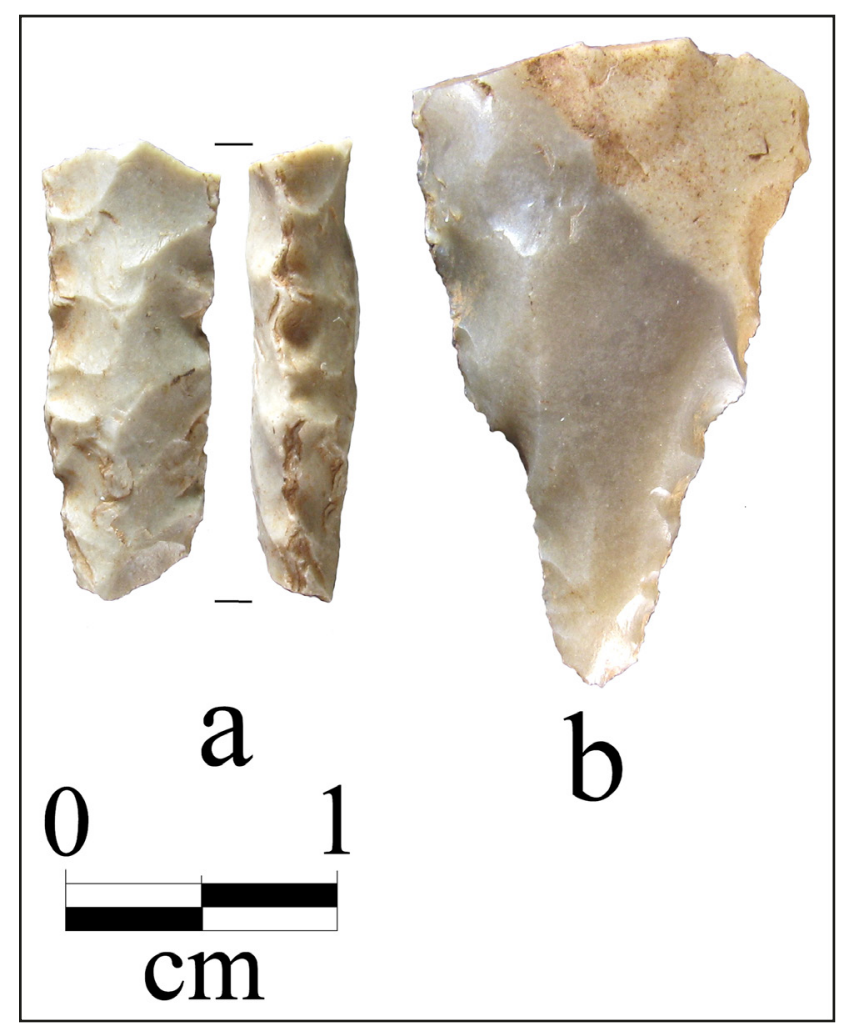

Figure 5. Drills from the Spradley site.

\section{Bifaces}

The recovered bifaces are from the northwestern area of archaeological deposits at the Spradley site, between N64-84 and W47-62 (Table 5), and from 0-40 cm bs. All of the bifaces are on local lithic raw materials (50 percent are on petrified wood), and these pieces represent evidence of the bifacial tool manufacture from local pebbles and cobbles by flake reduction (Figure 6). They range from 8-22 $\mathrm{mm}$ in thickness, and their intended end product was likely the completion of a bifacially flaked dart point for use during either the Late Archaic and/or the Woodland period occupations of the Spradley site.

Table 5. Bifaces from the Spradley site.

\begin{tabular}{|c|c|c|}
\hline Provenience & Raw Material & Description \\
\hline N84-W49, lv. 4 & petrified wood & $\begin{array}{l}\text { non-cortical, length, } 31+\mathrm{mm} \text {, width, } 33 \mathrm{~mm} \text {, } \\
\text { thickness, } 9 \mathrm{~mm}\end{array}$ \\
\hline N83-W47, lv. 3 & quartzite & $\begin{array}{l}\text { ovoid, non-cortical, length, } 50 \mathrm{~mm} \text {, width, } 46 \mathrm{~mm} \text {, } \\
\text { thickness, } 22 \mathrm{~mm}\end{array}$ \\
\hline N80-W62, lv. 2 & brown chert & $\begin{array}{l}\text { early stage, non-cortical, length, } 24.2 \mathrm{~mm} \text {, width, } \\
19.2 \mathrm{~mm} \text {, thickness, } 9.3 \mathrm{~mm}\end{array}$ \\
\hline N76-W65, lv. 4 & petrified wood & $\begin{array}{l}\text { cortex on } 1 \text { surface, length, } 58+\mathrm{mm} \text {, width, } 28 \mathrm{~mm} \text {, } \\
\text { thickness, } 10 \mathrm{~mm}\end{array}$ \\
\hline N64-W58, lv. 1 & brown chert & $\begin{array}{l}\text { early stage, non-cortical; length, } 28 \mathrm{~mm} \text {, width, } \\
17 \mathrm{~mm} \text {, thickness, } 8 \mathrm{~mm}\end{array}$ \\
\hline N64-W57, lv. 3 & petrified wood & $\begin{array}{l}\text { non-cortical, length, } 29+\mathrm{mm} \text {, width, } 28 \mathrm{~mm} \text {, } \\
\text { thickness, } 10.5 \mathrm{~mm}\end{array}$ \\
\hline
\end{tabular}




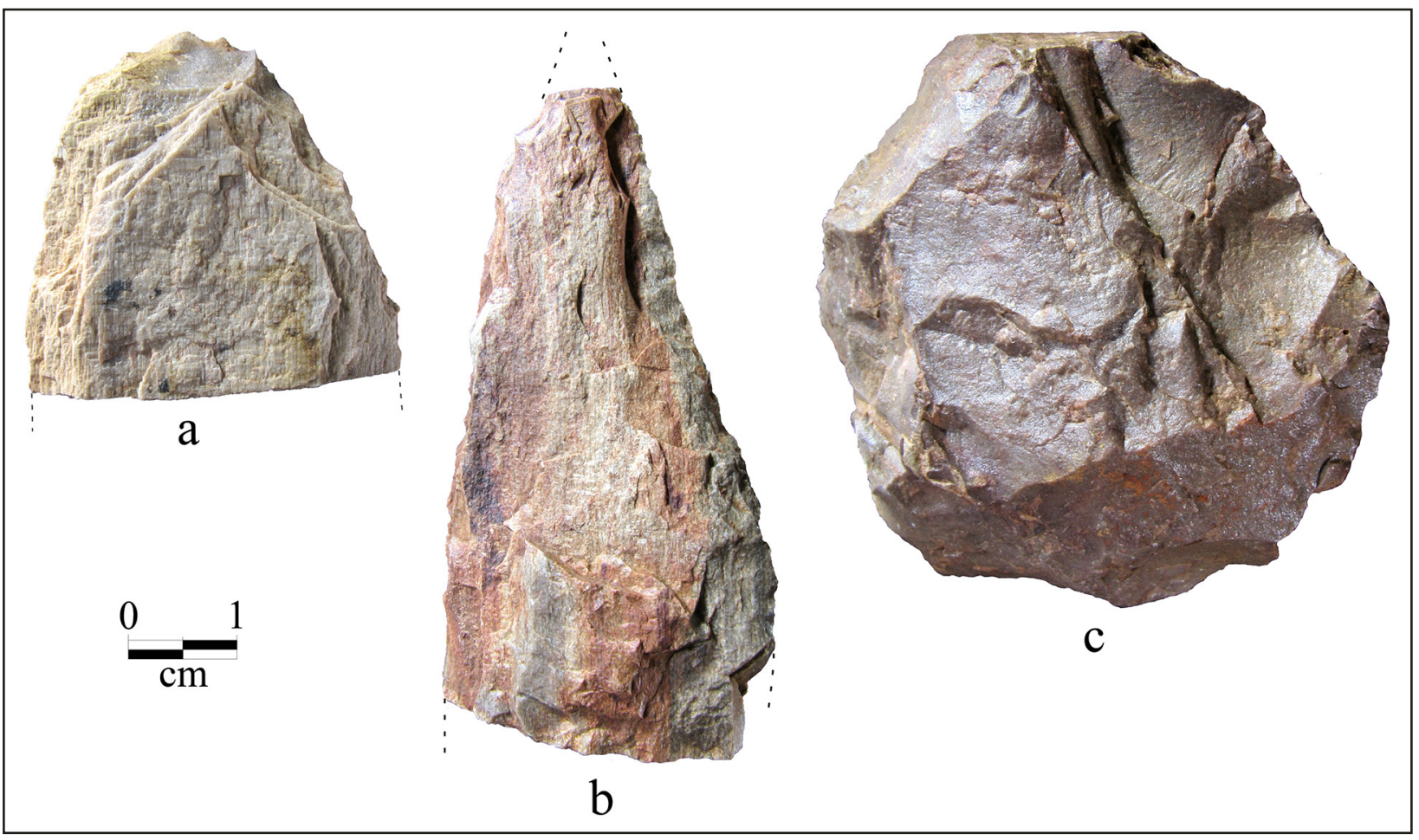

Figure 6. Bifaces from the Spradley site: a, N64-W57, lv. 3; b, N76-W65, lv. 4; c, N83-W47, Iv. 3.

\section{Dart Points}

Eighteen dart points and five dart point fragments are in the chipped stone tool assemblage at the Spradley site (Table 6). With only a few exceptions, the dart points were recovered from the northwest investigation area, suggesting this was the principal locus of both Late Archaic and Woodland utilized portions at the site. All of the dart points and dart point fragments are made from local lithic raw materials, almost exclusively (91 percent) from petrified wood. There are single examples of quartzite (Gary point) and red chert (tip fragment).

Table 6. Dart points from the Spradley site.

\begin{tabular}{|c|c|c|c|c|c|c|}
\hline Provenience & Type & Raw Material & $\mathrm{L}$ & W & Th & SW \\
\hline N80-W51, 1v. 3 & Gary & petrified wood & 32.6 & 19.8 & 7.2 & 13.0 \\
\hline N75-W64, 1v. 3 & Gary & quartzite & - & - & 10.5 & 15.0 \\
\hline N74-W65, lv. 1 & Gary & petrified wood & 25.9 & 16.8 & 5.6 & 14.0 \\
\hline N60-W40, lv. 3 & Gary & petrified wood & 48.0 & 21.1 & 10.9 & 11.5 \\
\hline N21-W17, lv. 1 & Gary & petrified wood & 35.0 & 19.2 & 7.0 & 9.4 \\
\hline N0-W20, lv. 3 & Gary & petrified wood & 28.0 & 18.9 & 9.5 & 9.6 \\
\hline N20-W15, lv. 1 & Godley & petrified wood & 42.2 & 15.2 & 7.5 & 10.2 \\
\hline N84-W47, lv. 1 & Kent & petrified wood & $34.0+$ & 29.0 & 10.8 & 18.2 \\
\hline N75-W65, lv. 3 & Kent & petrified wood & 42.0 & 20.0 & 10.0 & 12.9 \\
\hline N75-W63, lv. 4 & Kent & petrified wood & 39.1 & 24.0 & 4.8 & 17.0 \\
\hline
\end{tabular}


Table 6. Dart points from the Spradley site, cont.

\begin{tabular}{|c|c|c|c|c|c|c|}
\hline Provenience & Type & Raw Material & $\mathrm{L}$ & W & Th & SW \\
\hline N74-W52, 1v. 2 & Kent & petrified wood & $33.7+$ & $22.6+$ & 6.6 & 16.8 \\
\hline N65-W59, lv. 3 & Kent & petrified wood & - & 17.2 & 7.2 & 13.0 \\
\hline N60-W50, lv. 5 & Kent & petrified wood & - & 19.2 & 5.2 & 13.0 \\
\hline N60-W20, lv. 3 & Kent & petrified wood & $29.2+$ & 19.6 & 9.2 & 14.0 \\
\hline N76-W65, lv. 4 & Pontchartrain & petrified wood & 89.0 & 24.1 & 12.0 & 18.6 \\
\hline N69-W47, lv. 6 & Pontchartrain & petrified wood & 59.0 & 19.2 & 10.5 & 14.0 \\
\hline N73-W50, lv. 3 & Yarbrough & petrified wood & 49.2 & 22.9 & 7.6 & 16.0 \\
\hline N60-W30, lv. 2 & UID type & petrified wood & 32.0 & $15.1+$ & 5.1 & $10.0+$ \\
\hline N76-W63, lv. 3 & tip & red chert & - & - & 4.8 & - \\
\hline N75-W64, lv. 2 & tip & petrified wood & - & 23.0 & 7.8 & - \\
\hline N59-W37, lv. 4 & tip & petrified wood & - & - & 4.6 & - \\
\hline N80-W52, lv. 2 & tip/blade & petrified wood & - & 15.2 & 7.9 & - \\
\hline N60-W51, lv. 5 & blade & petrified wood & - & 24.7 & 8.1 & - \\
\hline
\end{tabular}

UID=unidentified; L=length; $\mathrm{W}=$ width; Th=thickness; SW=stem width

Five different dart points are present in the sample, including Gary ( $\mathrm{n}=6$, Figure 7a-b), Kent ( $\mathrm{n}=7$, Figure 7c-e), Godley (n=1, Figure 7f), Pontchartrain ( $\mathrm{n}=2$ (Figure 7h-i), and Yarbrough (n=1, Figure 7g); the Pontchartrain and Yarbrough dart points are of Late Archaic manufacture (ca. 5000-2500 years B.P.). The Gary, Godley, and Kent dart points are temporal diagnostics of the Woodland period (ca. 2500-1150 years B.P.) in this part of the Pineywoods (see Turner et al. 2011; Webb 2000; Anderson and Smith 2003). The one dart point of unidentified type had a rudimentary and broken contracting stem, and may be another Gary point

\section{Arrow Points}

Not including one arrow point made from chipped glass, there are 70 arrow points and fragments in the Spradley site tool assemblage. The arrow points occur in both the northwestern and southeastern parts of the investigated areas (Table 7). Arrow points comprise 55 percent of the chipped stone tools recovered in archaeological investigations at the site. 


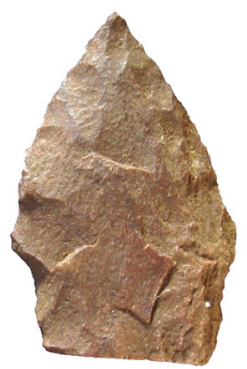

a

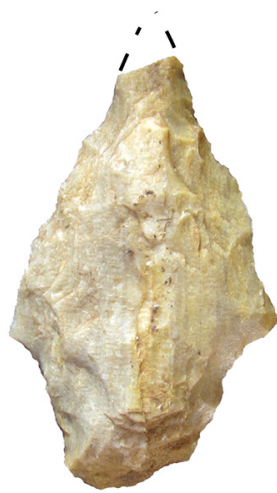

b

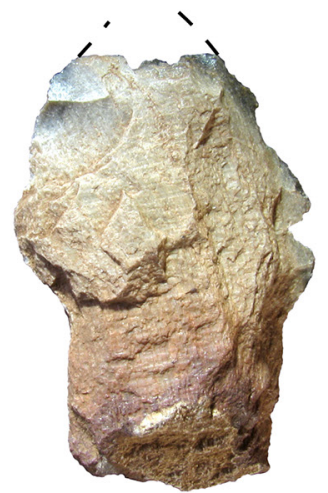

C

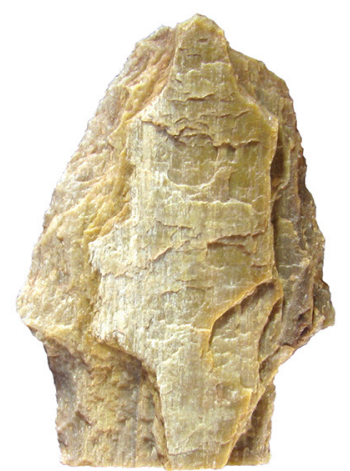

d

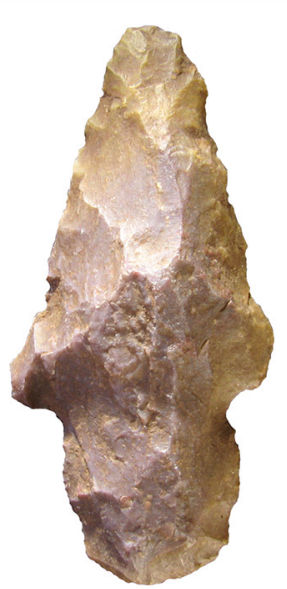

e

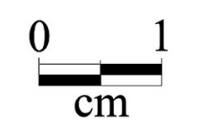

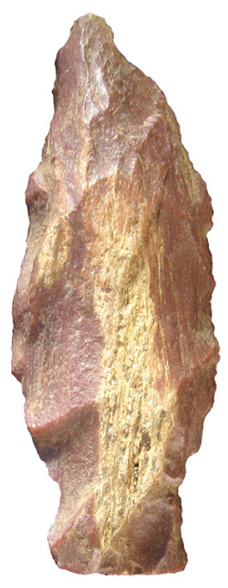

$\mathrm{f}$

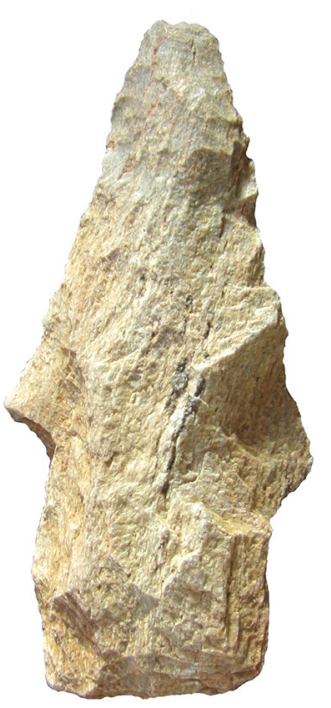

$\mathrm{g}$

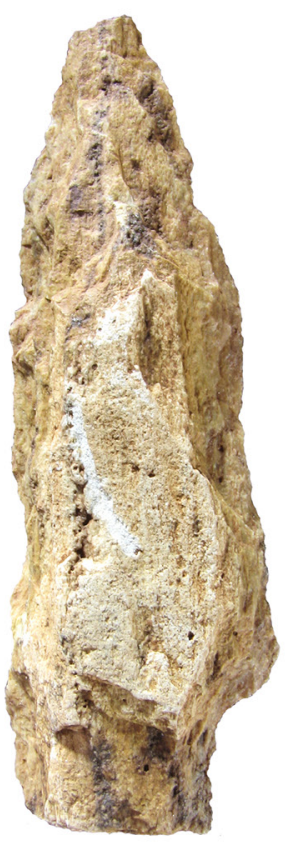

$\mathrm{h}$

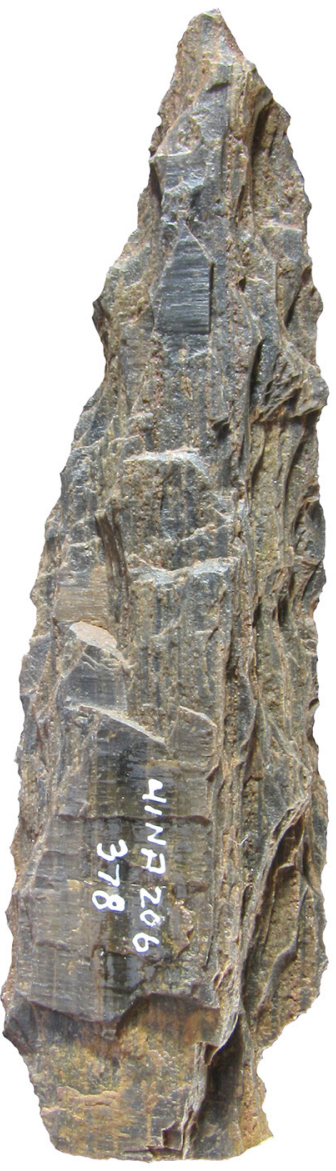

$\mathrm{i}$

Figure 7. Selected dart points in the Spradley site chipped stone tool assemblage. 
Table 7. Arrow points from the Spradley site.

\begin{tabular}{|c|c|c|c|c|c|c|}
\hline Provenience & Type & Raw Material & $\mathrm{L}$ & $\mathrm{W}$ & Th & SW \\
\hline N60-W50, lv. 2 & Alba & petrified wood & 24.5 & 16.2 & 4.1 & 5.1 \\
\hline N75-W64, lv. 3 & Bassett & petrified wood & $13.5+$ & 8.9 & 2.8 & 1.9 \\
\hline N69-W47, lv. 2 & Bassett & petrified wood & 14.5 & 17.6 & 3.8 & 2.5 \\
\hline N21-W17, lv. 2 & Bassett & petrified wood & 14.2 & 11.0 & 2.5 & 1.6 \\
\hline N74-W52, lv. 2 & Bonham & light red chert & 14.2 & 10.2 & 2.8 & 5.0 \\
\hline N74-W51, lv. 1 & Bonham & petrified wood & $20.7+$ & 17.0 & 3.2 & 5.4 \\
\hline N75-W64, lv. 2 & Colbert & petrified wood & 25.0 & 15.9 & 3.4 & 6.7 \\
\hline N65-W57, lv. 3 & Colbert & red chert & 18.8 & 11.2 & 2.2 & 3.1 \\
\hline N59-W38, lv. 1 & Cuney & translucent gray chert & 17.1 & 8.9 & 1.5 & 3.1 \\
\hline N80-W61, lv. 1 & Friley & petrified wood & 19.2 & 17.8 & 3.6 & 5.9 \\
\hline N80-W61, lv. 1 & Friley & quartzite & 17.1 & 11.0 & 2.4 & 5.7 \\
\hline N76-W63, lv. 1 & Friley & petrified wood & 21.0 & 18.0 & 2.1 & 5.7 \\
\hline N64-W58, lv. 2 & Friley & petrified wood & 14.2 & 8.8 & 2.5 & 4.9 \\
\hline N62-W49, lv. 1 & Friley & petrified wood & 18.7 & 15.0 & 3.2 & 5.1 \\
\hline N84-W47, lv. 1 & Perdiz & brownish-gray chert & $22.8+$ & 14.0 & 4.6 & 4.4 \\
\hline N83-W48, lv. 2 & Perdiz & petrified wood & 17.8 & 12.7 & 1.4 & 2.6 \\
\hline N74-W50, lv. 1 & Perdiz & red chert & 16.2 & 16.3 & 3.0 & 2.5 \\
\hline N65-W59, lv. 2 & Perdiz & petrified wood & 18.0 & 14.0 & 2.3 & 2.8 \\
\hline N65-W57, 1v. 2 & Perdiz & petrified wood & $18.0+$ & 14.9 & 2.8 & 1.8 \\
\hline N64-W59, 1v. 2 & Perdiz & petrified wood & 12.9 & 10.0 & 1.5 & 2.0 \\
\hline N64-W58, lv. 1 & Perdiz & brown chert & 16.1 & 12.0 & 2.1 & 2.0 \\
\hline N62-W49, lv. 4 & Perdiz & brown chert & $17.6+$ & 15.4 & 3.0 & 3.8 \\
\hline N61-W48, 1v. 3 & Perdiz & petrified wood & 19.0 & $12.8+$ & 3.3 & 4.7 \\
\hline N61-W47, 1v. 2 & Perdiz & quartzite & 17.2 & 12.2 & 2.5 & 2.0 \\
\hline N60-W50, lv. 2 & Perdiz & petrified wood & 21.5 & 13.5 & 2.3 & 5.2 \\
\hline N60-W50, lv. 2 & Perdiz & petrified wood & $17.9+$ & 17.0 & 2.3 & 4.4 \\
\hline N60-W50, lv. 6 & Perdiz & brown chert & 11.6 & 9.0 & 2.2 & 1.9 \\
\hline N60-W47, UID lv. & Perdiz & brown chert & 16.9 & 9.3 & 3.0 & 1.4 \\
\hline N58-W39, lv. 1 & Perdiz & petrified wood & $14.0+$ & 14.1 & 1.9 & 3.0 \\
\hline N58-W39, lv. 1 & Perdiz & petrified wood & 20.0 & 14.0 & 3.1 & 3.0 \\
\hline N58-W38, 1v. 1 & Perdiz & petrified wood & 20.2 & $13.0+$ & 2.7 & 3.3 \\
\hline N57-W47, 1v. 1 & Perdiz & petrified wood & 24.0 & $12.9+$ & 4.2 & 3.7 \\
\hline N26-W17, lv. 2 & Perdiz & translucent gray chert & $36.9+$ & 17.0 & 2.0 & 3.2 \\
\hline N26-W16, lv. 2 & Perdiz & brown chert & 20.1 & 13.9 & 2.5 & 2.8 \\
\hline N21-W17, 1v. 4 & Perdiz & petrified wood & 23.9 & 17.0 & 4.4 & 3.8 \\
\hline N21-W16, lv. 1 & Perdiz & brown chert & 27.0 & 12.0 & 3.1 & 2.8 \\
\hline N11-W21, lv. 1 & Perdiz & petrified wood & 16.9 & 9.0 & 2.1 & 4.0 \\
\hline
\end{tabular}


Table 7. Arrow points from the Spradley site, cont.

\begin{tabular}{|c|c|c|c|c|c|c|}
\hline Provenience & Type & Raw Material & $\mathrm{L}$ & $\mathrm{W}$ & $\mathrm{Th}$ & SW \\
\hline N80-W62, lv. 3 & cf. Perdiz & petrified wood & 23.0 & 13.1 & 3.8 & 2.8 \\
\hline N80-W0, lv. 2 & cf. Perdiz & petrified wood & $24.1+$ & 16.0 & 3.8 & 5.3 \\
\hline N75-W65, lv. 2 & cf. Perdiz & red chert & $16.7+$ & 17.0 & 5.1 & 6.2 \\
\hline N73-W63, lv. 3 & cf. Perdiz & brown chert & 19.0 & 14.1 & 2.5 & 4.7 \\
\hline N74-W51, lv. 2 & cf. Perdiz & petrified wood & 18.2 & 11.2 & 3.3 & 2.5 \\
\hline N73-W50, lv. 3 & cf. Perdiz & petrified wood & 20.5 & 12.9 & 3.8 & 4.8 \\
\hline N73-W50, lv. 2 & cf. Perdiz & petrified wood & $17.0+$ & 13.1 & 3.7 & 5.7 \\
\hline N61-W52, lv. 1 & cf. Perdiz & red chert & $14.0+$ & 10.2 & 2.5 & 3.6 \\
\hline N11-W20, lv. 2 & Scallorn & red chert & 13.7 & 11.0 & 1.8 & 5.0 \\
\hline N81-W50, lv. 5 & cf. Turney & $\begin{array}{l}\text { translucent dark } \\
\text { grayish-brown chert }\end{array}$ & 30.0 & 14.1 & 2.7 & - \\
\hline N65-W58, lv. 1 & cf. Turney & dark gray chert & 29.0 & 13.1 & 2.5 & - \\
\hline N65-W57, lv. 3 & cf. Turney & gray chert & 201. & $12.5+$ & 3.2 & - \\
\hline N11-W20, 0-20 & cf. Turney & translucent gray chert & - & 14.0 & 1.6 & - \\
\hline N80-W51, lv. 2 & UID type & gray chert & 32.0 & 12.1 & 4.3 & 7.9 \\
\hline N76-W65, lv. 2 & UID type & petrified wood & 25.4 & 10.0 & 4.6 & 5.8 \\
\hline N80-W50, lv. 3 & blade/notch & petrified wood & - & 12.5 & 2.1 & - \\
\hline N80-W61, lv. 1 & tip & gray chert & - & 8.3 & 2.4 & - \\
\hline N80-W60, lv. 3 & tip & red chert & - & 11.5 & 3.0 & - \\
\hline N75-W63, lv. 2 & tip & petrified wood & - & 12.1 & 4.0 & - \\
\hline N69-W47, lv. 2 & tip & petrified wood & - & 8.0 & 3.3 & - \\
\hline N62-W49, lv. 2 & tip & translucent gray chert & - & 10.9 & 2.5 & - \\
\hline N58-W39, lv. 1 & tip & petrified wood & - & 8.3 & 1.3 & - \\
\hline N80-W62, lv. 2 & tip/blade & petrified wood & $15.6+$ & 12.2 & 2.4 & - \\
\hline N80-W50, lv. 3 & tip/blade & brown chert & - & 12.6 & 3.0 & - \\
\hline N65-W59, lv. 2 & tip/blade & bluish-green glass & - & 17.5 & 2.5 & - \\
\hline N61-W48, lv. 2 & tip/blade & petrified wood & - & 9.9 & 2.3 & - \\
\hline N60-W50, lv. 2 & tip/blade & $\begin{array}{l}\text { brownish-gray } \\
\text { translucent chert }\end{array}$ & $20.9+$ & $17.5+$ & 3.9 & - \\
\hline N50-W50, lv. 3 & tip/blade & gray chert & - & 10.0 & 1.5 & - \\
\hline N26-W17, lv. 3 & tip/blade & red chert & - & 14.8 & 2.6 & - \\
\hline N25-W17, lv. 1 & tip/blade & brown chert & - & 9.3 & 1.7 & - \\
\hline N25-W17, lv. 1 & tip/blade & brown chert & - & 17.5 & 2.3 & - \\
\hline N25-W17, lv. 3 & tip/blade & brown chert & - & 10.2 & 1.6 & - \\
\hline N25-W15, lv. 3 & tip/blade & brown chert & - & 12.8 & 2.1 & - \\
\hline N10-W22, lv. 6 & tip/blade & quartzite & - & 10.5 & 3.9 & - \\
\hline
\end{tabular}

UID=unidentified; L=length; $\mathrm{W}=$ width; Th=thickness; SW=stem width 
Most of the arrow points are made on local lithic raw materials (83 percent) - among them petrified wood, quartzite, and local earth-toned cherts - but 17 percent are made on non-local cherts (see Table $7)$. One arrow point fragment is made from a bluish-green glass. This includes the one Cuney arrow point, two of the Perdiz and cf. Perdiz points (6.5 percent), all four of the cf. Turney arrow points, one unidentified arrow point, and four (22 percent) of the fragmentary arrow points. None of the Alba, Bassett, Bonham, Colbert, Friley, and Scallorn arrow points in the assemblage are made from non-local lithic raw materials.

The oldest arrow point styles in the arrow point assemblage include Friley $(n=5)$ and Scallorn $(n=1)$ points (Figures 8 and 9), and these may have been manufactured during late Woodland period times (ca. A.D. 700-900), when arrow points first began to be made in East Texas (Shafer and Walters 2010). These are followed by ca. A.D. 900-1200 arrow point styles - the Alba $(n=1)$ and Colbert $(n=2)$ types (Figure $9 b-d)$. There are two Bonham arrow points in the assemblage (Figure 10), and these are considered likely to date from ca. A.D. 1200-1400, indicating some use of the Spradley site during the Middle Caddo period.

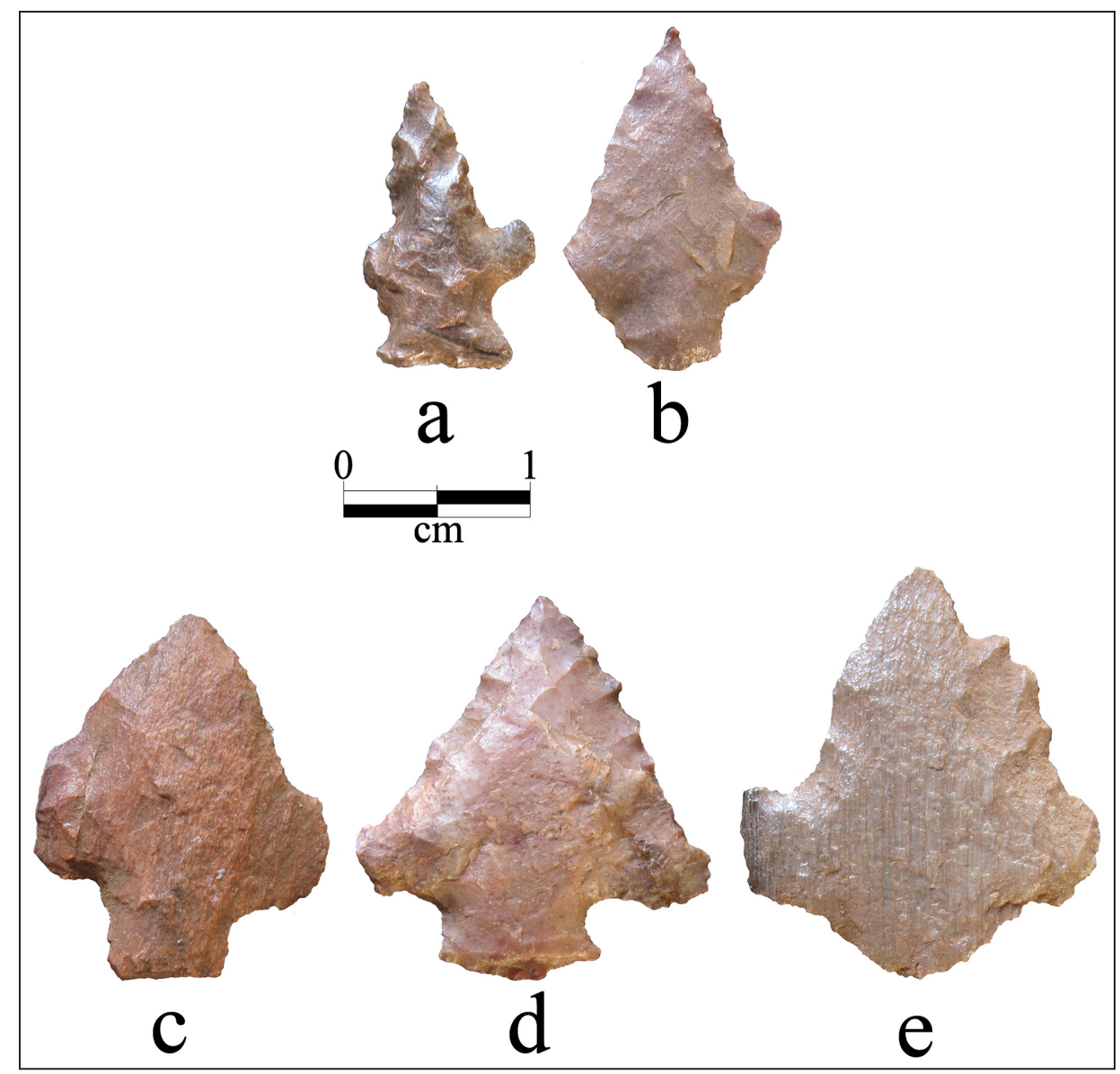

Figure 8. Friley arrow points from the Spradley site.

A Late Caddo arrow point type in the assemblage is the Bassett point ( $n=3$, Figure 11). Girard (1995:152) suggests Bassett and Perdiz arrow points are associated in the Historic Caddo component at the Deshazo site, and this may well be the case at the Spradley site, but in other East Texas contexts, they tend to be found in deposits dating from ca. A.D. 1500-1680. 


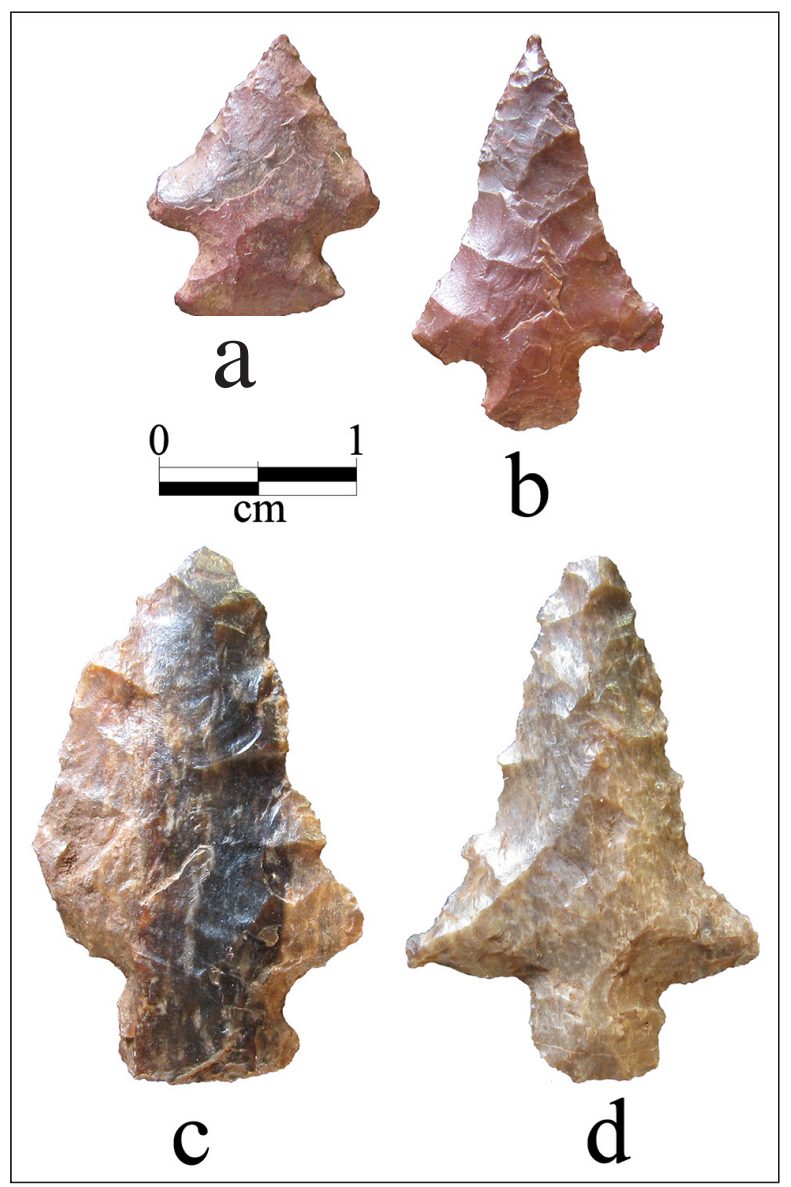

Figure 9. Scallorn, Colbert, and Alba arrow points from the Spradley site.

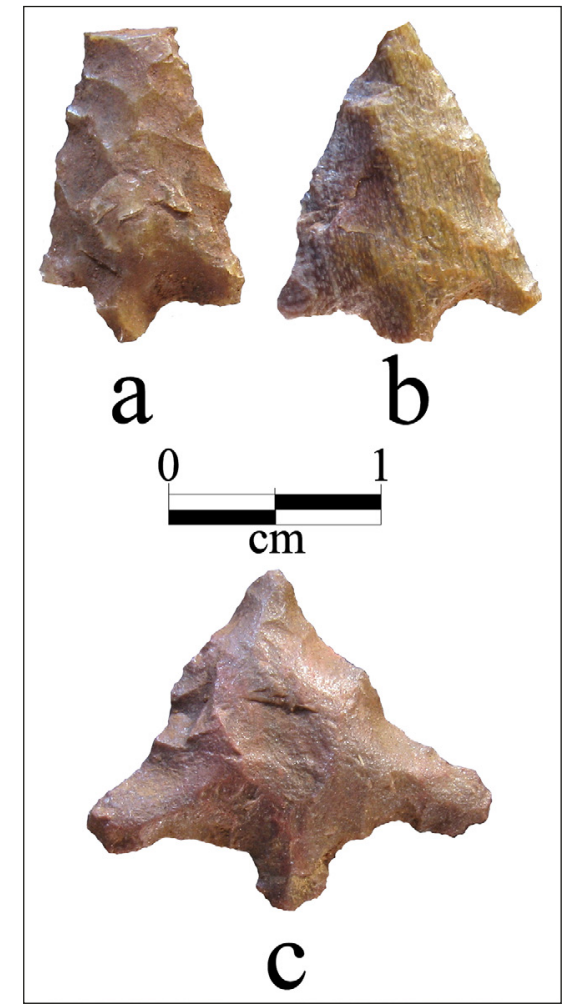

Figure 11. Bassett arrow points from the Spradley site.

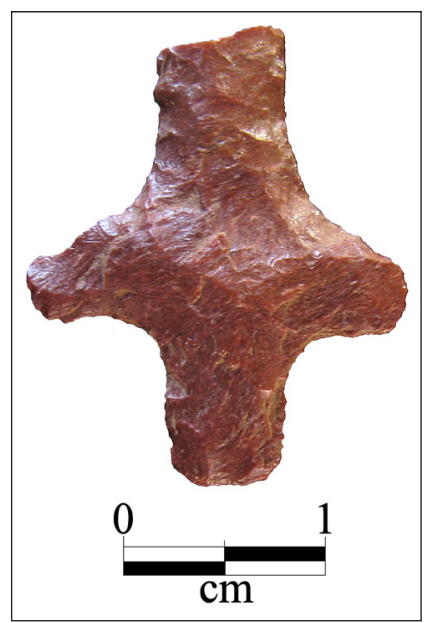

Figure 10. Bonham arrow points from the Spradley site.
The majority of the arrow points are thought to be associated with the principal Caddo occupation, one dating to early Historic period times. This includes 23 Perdiz points (Figure 12), cf. Perdiz points (with a rounded or flat contracting stem, often unifacially manufactured, $n=8$ ) (Figure 13), cf. Turney (a triangular form with a slight concave base, $n=4)$ (Figure 14a-d), and a single Cuney point (Figure 15) (see Turner et al. 2011). The one bluish-green glass arrow point fragment also is part of this component (Figure 16, see below).

On Historic Caddo sites in East Texas, triangular arrow point forms are predominant on sites from the Sabine River north to the Red River, while Perdiz, Cuney, and Turney arrow points occur almost exclusively on Historic Caddo sites in the Neches and Angelina river basins (Table 8). At the Spradley site, Perdiz and cf. Perdiz points comprise 86 percent of the arrow points in the Historic Caddo period component, compared to 11 percent $\mathrm{cf}$. Turney arrow points, and 3 percent that are Cuney points. The proportion of Perdiz points at the Spradley site is much more like the assemblage 


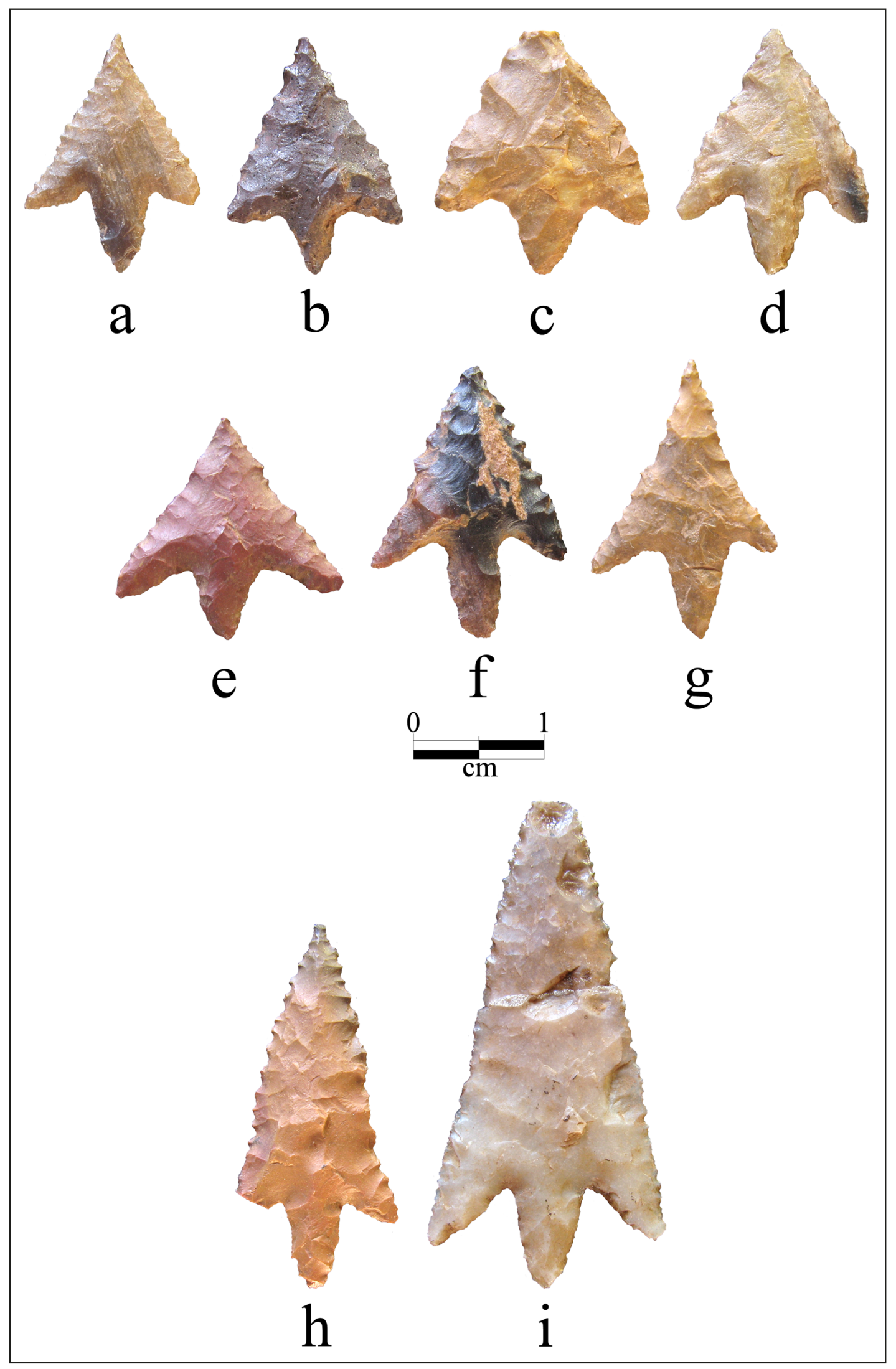

Figure 12. Perdiz arrow points from the Spradley site. 


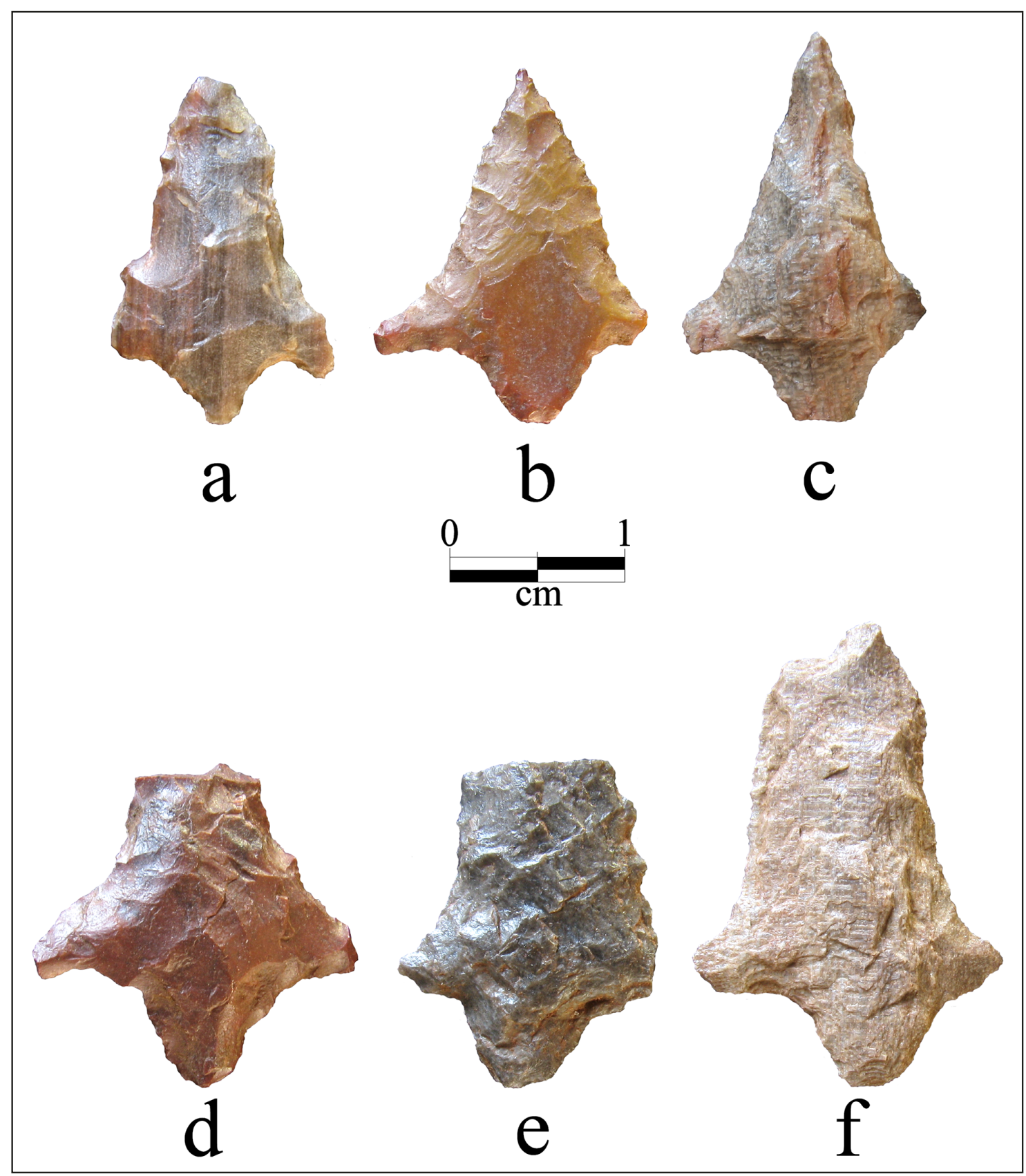

Figure 13. cf. Perdiz arrow points from the Spradley site.

at the Deshazo site (96 percent of all the arrow points are Perdiz) (see Girard 1995) than at the younger $18^{\text {th }}$ century Henry M. settlement, where only 8.3 percent are Perdiz points. Instead, at the Henry M. site, Turney and triangular Fresno points represent 67 percent of the arrow point assemblage (see Perttula et al. 2010:Table 17), compared to only 1.6 percent at the Deshazo site and 11 percent at the Spradley site. Similarly, Cuney points are relatively abundant at Henry M., accounting for 25 percent of the assemblage, but only between 2.4-3 percent of the arrow points at the Desahzo and Spradley sites. In any events, these changes in arrow point styles suggest that there were rapid changes in the style and use of arrow points over time in the early years of contact between Europeans and Caddos in East Texas. 


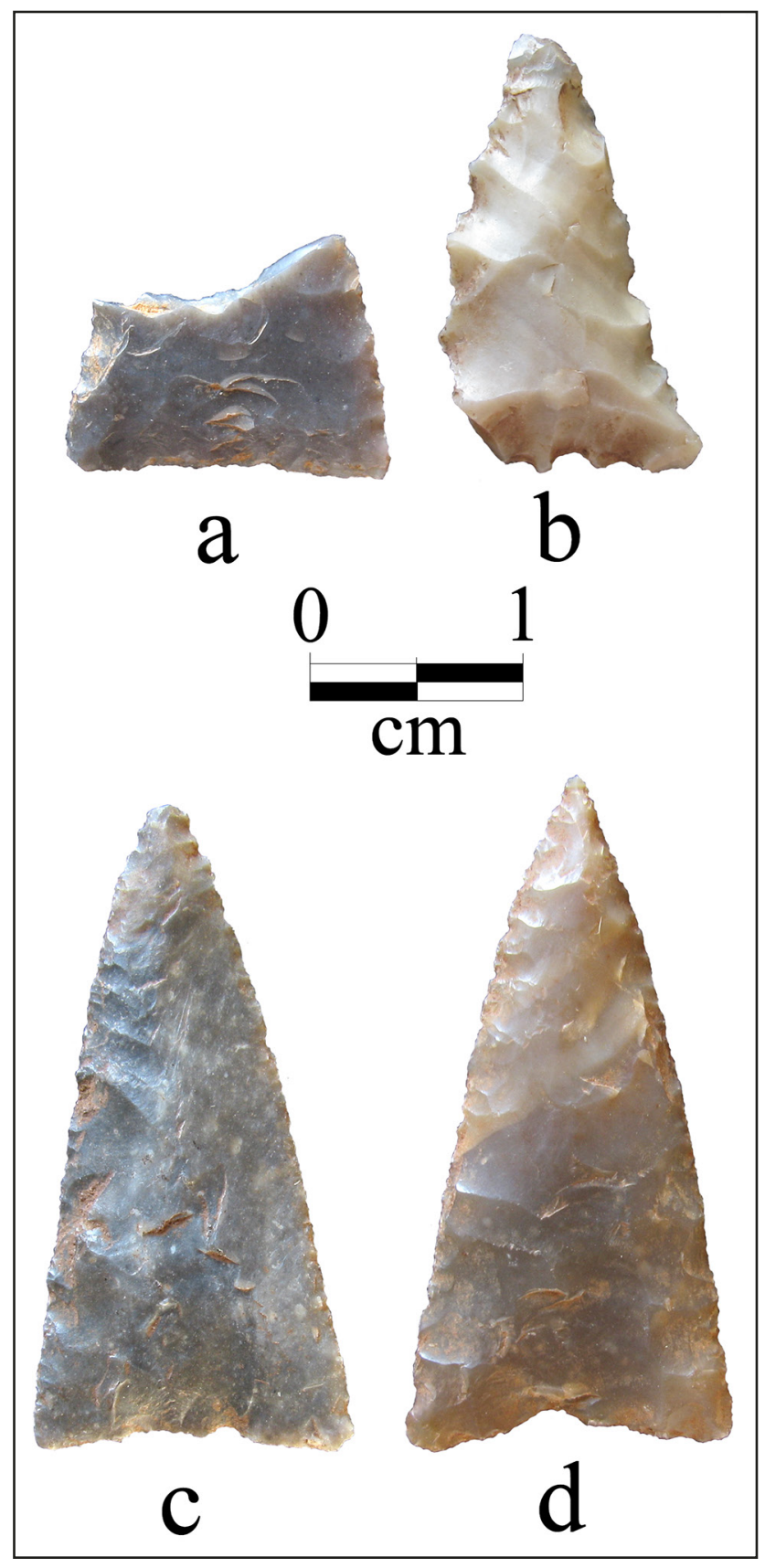

Figure 14. cf. Turney arrow points from the Spradley site.

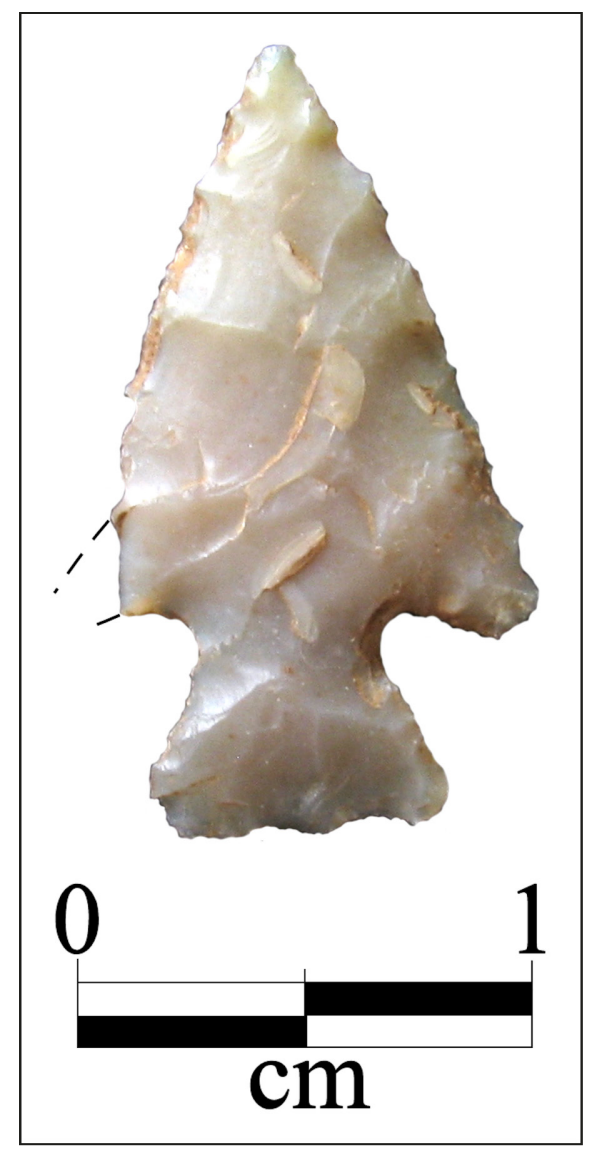

Figure 15. Cuney arrow point from the Spradley site.

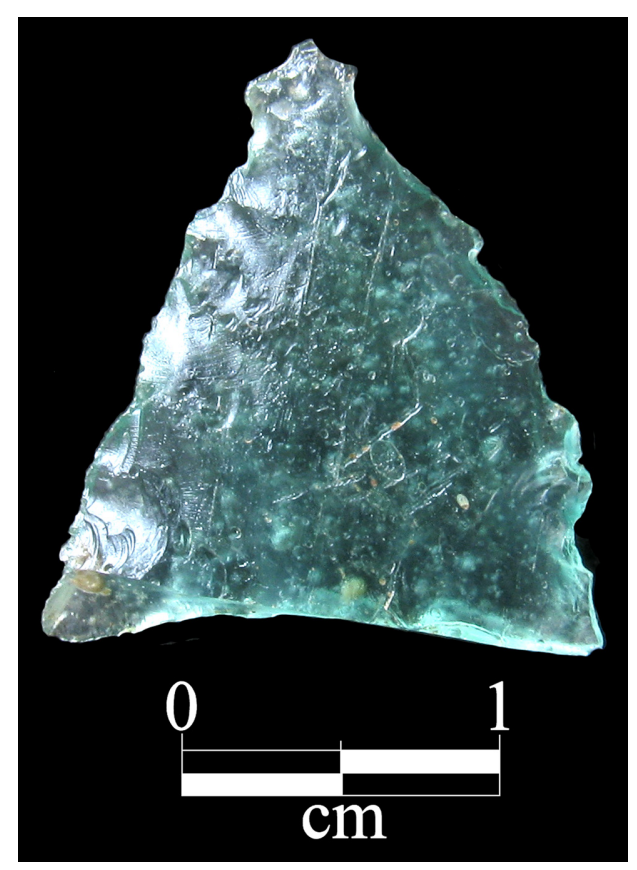

Figure 16. Arrow point fragment from the Spradley site made from a bluishgreen glass. 


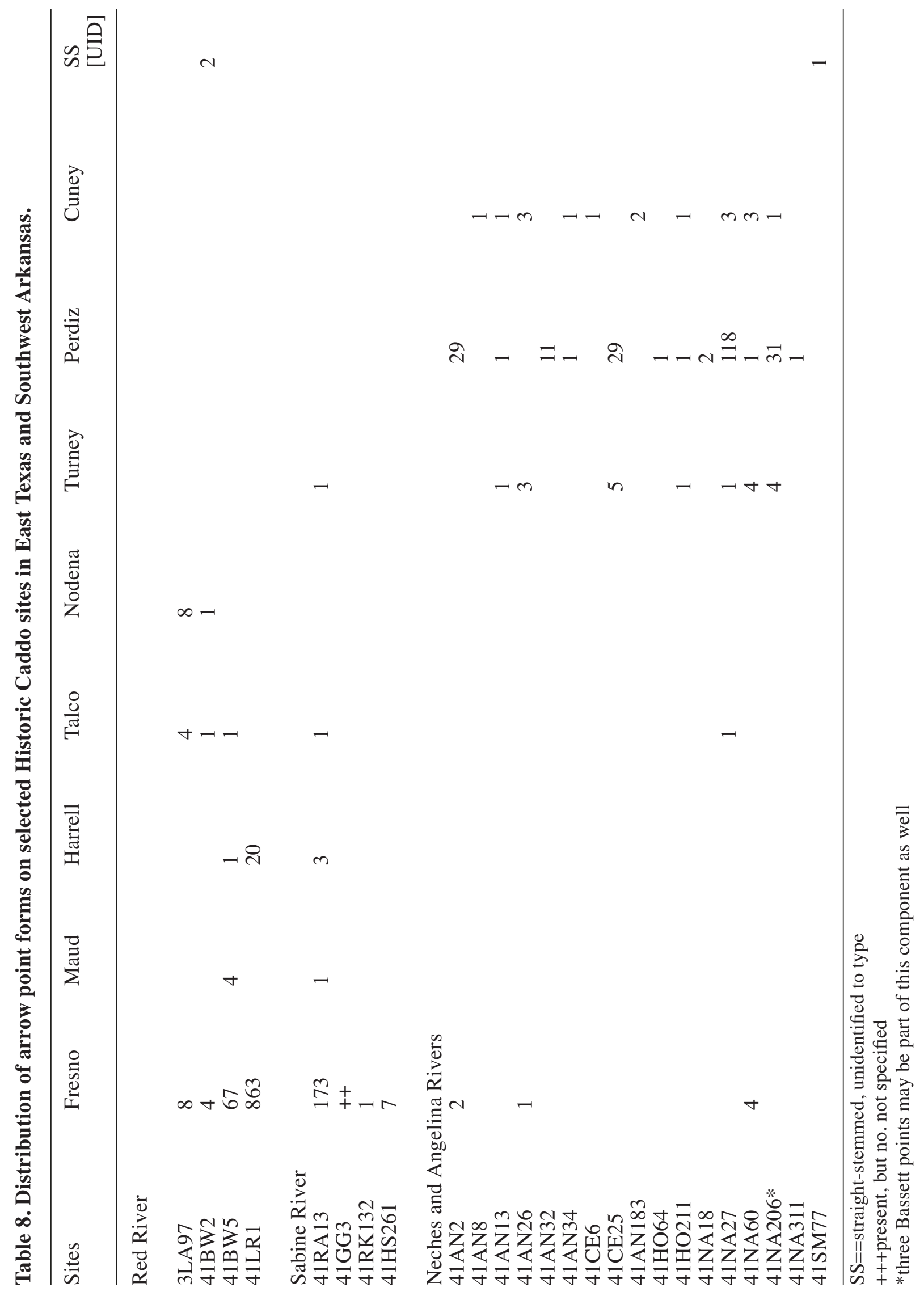


These mutually distinctive distributions suggest that there were two contemporaneous social networks of Caddo communities in East Texas: (1) a northern network of Kadohadacho, Nasoni, and Nadaco groups, and their descendants in the upper Sabine River basin, in the Red, Big Cypress, and Sabine river basins (areas in black on Figure P), and (2) a southern Hasinai Caddo network of communities in the Neches and Angelina river basins (areas in gray on Figure 17). Based also on some shared ceramic vessel types and arrow point types, this latter network of Caddo communities were also interacting with Nadaco Caddo communities on the Sabine River as well as Caddo groups on the upper Sabine River basin (Figure 17).

One of the unidentified arrow points has an expanding stem, a concave base, one barbed shoulder, but is corner-notched (Figure 18). The other (N76-W65, level 2) has an expanding stem, a convex base, and no barbs.

\section{Arrow Point Preforms}

Arrow point preforms are common in both the northwestern and southeastern portions of the Spradley site, with 12 recovered preforms (Table 9). The preforms are ovoid to triangular-shaped, and generally they are unifacially flaked (Figure 19a-f). The form of three of the preforms suggest they were preforms abandoned in the course of manufacturing either Perdiz or Bassett points.

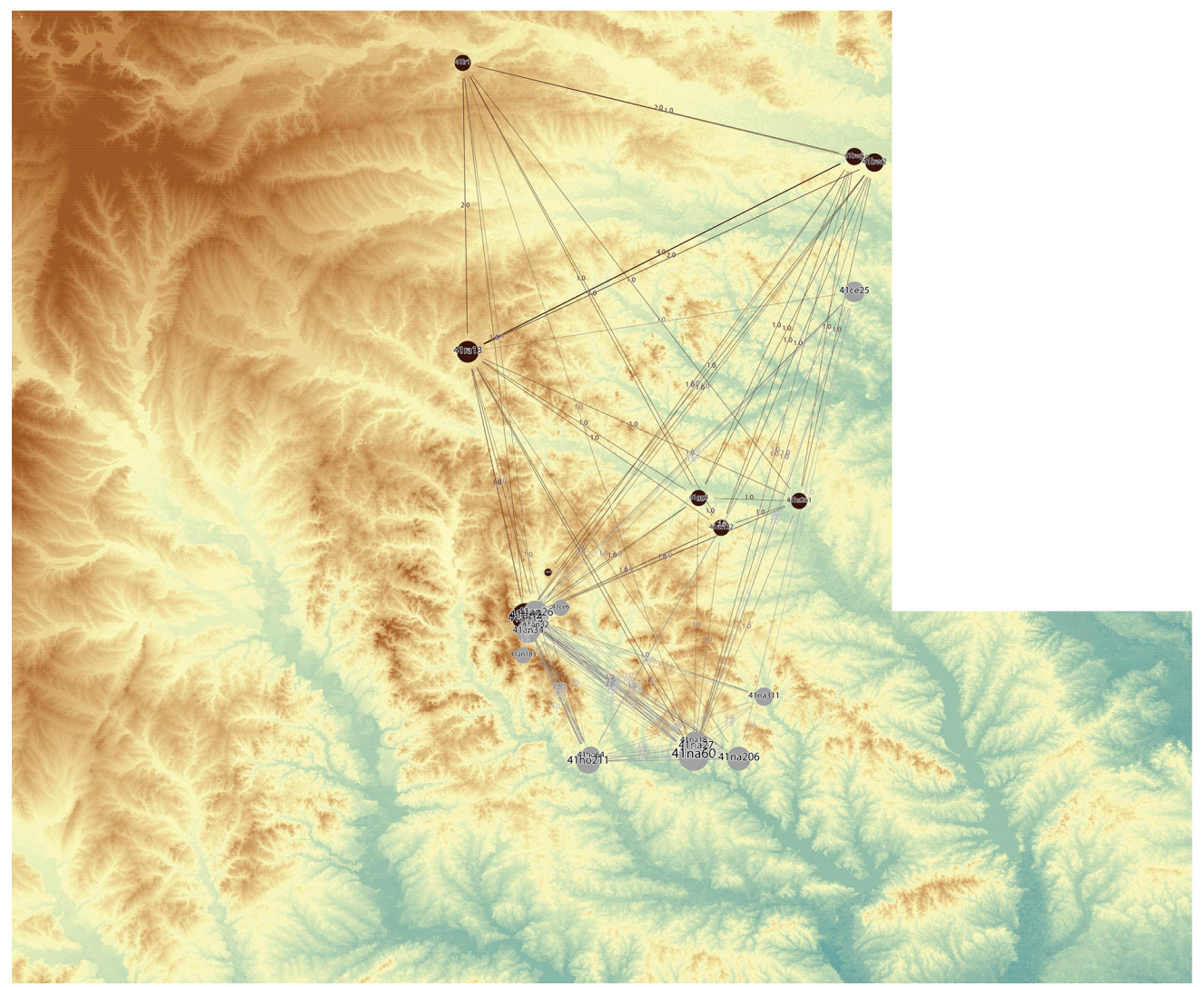

Figure 17. Social networks of northern and southern Historic Caddo groups in East Texas. Figure provided courtesy of Robert Z. Selden, Jr.

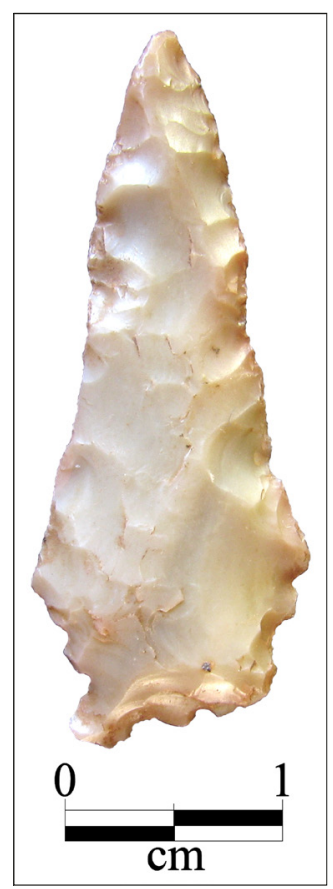

Figure 18.

Unidentified arrow point from N80-W51, level 2 at the Spradley site. 
Table 9. Arrow point preforms from the Spradley site.

\begin{tabular}{lllllll}
\hline Provenience & Raw Material & L & W & Th & SW & \\
\hline N81-W60, lv. 2 & petrified wood & 30.2 & 19.0 & 4.3 & - & triangle-shaped \\
N80-W60, lv. 3 & translucent gray & 23.9 & $19.0+$ & 4.9 & - & triangle-shaped \\
N76-W63, lv. 5 & petrified wood & 23.8 & 20.2 & 3.9 & - & triangle-shaped \\
N74-W52, lv. 2 & dark brown chert & 21.6 & 14.0 & 4.8 & - & Ovoid-shaped \\
N61-W48, lv. 4 & petrified wood & 32.8 & 12.8 & 5.3 & 5.6 & cf. Perdiz \\
N60-W50, lv. 3 & brown chert & 26.4 & 18.0 & 3.2 & - & Ovoid-shaped \\
N59-W39, lv. 1 & translucent gray & - & 18.0 & 4.5 & - & Ovoid-shaped \\
& chert & & & & & Ovoid-shaped \\
N40-W20, lv. 2 & petrified wood & 22.9 & 12.0 & 5.1 & - & cf. Bassett \\
N26-W17, lv. 2 & brownish-red chert & $23.1+$ & 16.9 & 3.7 & - & Ovoid-shaped \\
N26-W16, lv. 3 & brown chert & - & 18.3 & 4.4 & - & triangle-shaped \\
N20-W26, lv. 2 & petrified wood & 31.0 & 21.9 & 4.8 & - & cf. Bassett \\
N10-W21, lv. 1 & brown chert & - & 21.0 & 2.4 & 5.3 & \\
\hline
\end{tabular}

L=length; $\mathrm{W}=$ width; Th=thickness; $\mathrm{SW}=$ stem width

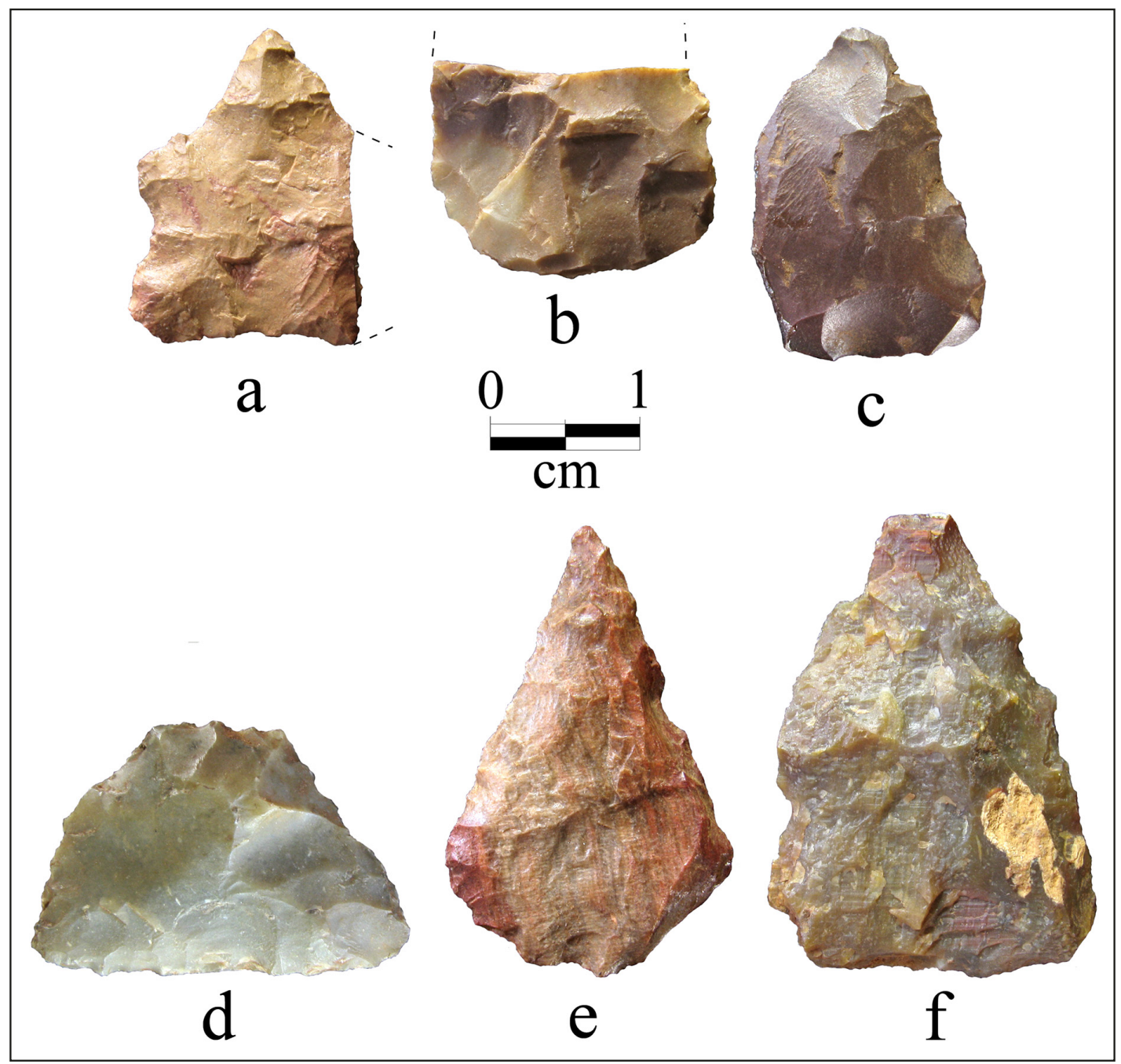

Figure 19. Arrow point preforms from the Spradley site. 
Twenty-five percent of the arrow point preforms are on non-local translucent gray or dark brown chert. These are probably from Central Texas chert sources, particularly the translucent gray chert. By contrast, the arrow point preforms $(n=8)$ from the Henry M. site are all on non-local Central Texas cherts (Perttula et al. 2010:35).

\section{Ground Stone Tools}

The ground stone tools from the Spradley site include manos $(n=4)$, mano-pitted stones $(n=3)$, pitted stones $(n=2)$, and grinding slab fragments $(n=3)$ (Table 10). More than 90 percent of the ground stone tools are from excavation units in the northwestern part of the site; only one pitted stone came from archaeological deposits in the southeastern part of the site.

Table 10. Ground stone tools from the Spradley site.

\begin{tabular}{lllll}
\hline Provenience & $\begin{array}{l}\text { Raw Material } \\
(\mathrm{mm})\end{array}$ & $\begin{array}{l}\mathrm{L} \\
(\mathrm{mm})\end{array}$ & $\begin{array}{l}\text { W } \\
(\mathrm{mm})\end{array}$ & Th \\
\hline
\end{tabular}

1-sided grinding slab and slab fragments

N81-W61, 1v. 3

N69-W48, lv. 3

N62-W47, lv. $4 \quad$ FSS

1-sided mano fragment

N50-W40, lv. 5

FSS

$-$

$-$ 36

2-sided mano and mano fragments

N80-W52, lv. 5

N67-W47, lv. 6

N61-W47, lv. 2
FSS

Hematite

FSS

\section{-}

105

$\begin{array}{ll}- & 11 \\ - & 14 \\ 59 & 25\end{array}$

2-sided mano and 1-sided pitted stone

N64-W59, lv. 4

FSS

79

56

2-sided mano and 2-sided pitted stone

N57-W47, lv. 2

FSS

86

59

1-sided mano and pitted stone

N80-W52, lv. 5

FSS

73

54

1-sided pitted stone

N80-W60, lv. 6

FSS

-

N21-W16, lv. 2

FSS

109

67

32 
The ground stone tools are made from locally-available ferruginous sandstone ( 92 percent) and hematite ( 8 percent). The diameter of the pits on the pitted manos and pitted stones ranges from 15$26 \mathrm{~mm}$, with a mean diameter of $20.7 \mathrm{~mm}$. The emphasis on grinding slabs, manos, and pitted stones suggests these implements were used in the grinding and processing of plant foods.

A similar range of ground stone tools were found in the much larger ground stone tool assemblage $(n=159)$ at the Deshazo site (see Varien 1995:31-32); many (i.e., pitted stones, pitted manos, and polishing stones) of these tools were apparently associated with the Woodland period occupation of the site, but others were part of the Historic Caddo tool kit (i.e., manos, celts, and abraders) as they were at the Historic Caddo Allen phase Henry M. site (41NA60). At the latter site, the 39 ground stone tools included manos (44 percent), mano-pitted stones (2.6 percent), pitted stones (15.4 percent), grinding slabs (15.4 percent), metates (5.1 percent), and grooved abraders (18.0 percent (Perttula et al. 2010:4748).

\section{Glass Arrow Point}

One of the arrow points in the assemblage is made from a piece of bluish-green glass that is flat and only $2.5 \mathrm{~mm}$ in thickness (see Figure 16); it was recovered in Unit N65-W59, level $2(10-20 \mathrm{~cm}$ bs). The point is broken and only the tip and serrated blade remain; the blade is $17.5 \mathrm{~mm}$ in width.

\section{Ceramic Vessel Sherds and Pipes, by Paul Shawn Marceaux and Timothy K. Perttula}

\section{Ancestral Caddo Ceramic Artifacts}

The large assemblage of ancestral Caddo ceramic vessel sherds, more than 8800 in total, recovered in the work at the Spradley site were analyzed in detail by Marceaux (2011:361-376, and Appendix 2-5). A summary of the findings of those analyses are presented in this section of the report.

The 8806 sherds are from plain wares, utility wares, and fine wares (Table 11). The plain wares comprise 52 percent of the collection; 37 percent of the rim sherds are from plain vessels. Sherds from utility ware vessels account for 37 percent of the assemblage, as well as 37 percent of the rims, and fine wares only account for 10.5 percent of the sherds from the site; fine ware rims represent, however, 25 percent of the assemblage.

Table 11. Ceramic wares at the Spradley site.

\begin{tabular}{lllll}
\hline Sherd type & Plain ware & Utility ware & Fine ware & N \\
\hline Rim & 184 & 181 & 124 & 489 \\
Body & 4399 & 3046 & 803 & 8248 \\
Base & 67 & 2 & - & 69 \\
\hline Totals & 4650 & 3229 & 927 & 8806 \\
\hline
\end{tabular}

Ceramic metrics for the assemblage include a plain/decorated sherd ratio of 1.12, a brushed to plain sherd ratio of 0.51 , and a brushed to other wet paste sherd ratio of 2.68. Brushed marks are present on 56.6 percent of the decorated sherds $(n=4156)$. 
Sherds that compare favorably to a number of types known to occur on other Neches-Angelina River basin ancestral Caddo sites of late Frankston phase age (ca. A.D. 1560-1680), or date to the early part of the Allen phase (ca. A.D. 1680-1720), were identified in the Spradley site assemblage. They include the following types:

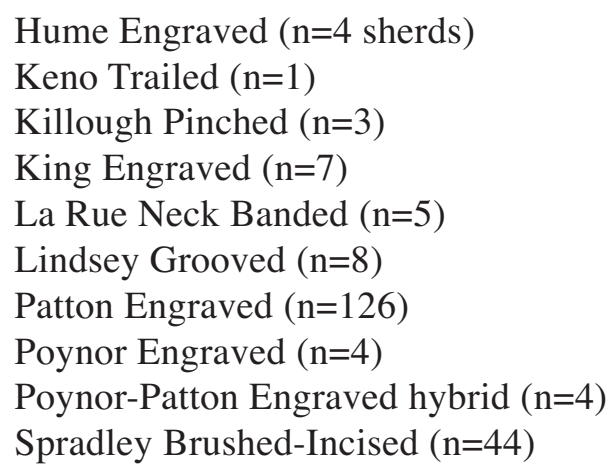

Clearly most of the sherds of identifiable type in the assemblage are from Patton Engraved fine ware vessels and Spradley Brushed-Incised utility ware vessels.

The ceramic sherds from the Spradley site are from vessels tempered primarily with grog (fired clay) or burned bone (Table 12). Grog occurs in 56 percent of the sherds, with the highest proportions in the utility wares (61 percent), while bone temper is present in 35 percent of the sherds; the highest proportion of bone use is in the fine wares (41 percent). Crushed hematite is present in 7 percent of the sherd sample, with the highest proportion of this temper present in the fine wares. Vessels made with shell temper are from non-locally produced wares, likely made by Caddo groups along the Red River to the northeast in Northwest Louisiana and Southwest Arkansas (see Perttula et al. 2012). Only 0.7 percent of the sherds in the sample have shell temper. Finally, 0.3 percent of the sherds apparently were tempered only with plant organic remains, or had organic remains left in the relatively unprocessed clay paste when certain vessels were fired.

Table 12. Temper use in a detailed sherd analysis sample from the Spradley site.*

\begin{tabular}{lllll}
\hline Temper & Plain ware & Utility ware & Fine ware & N \\
\hline grog & 425 & 817 & 172 & 1414 \\
bone & 320 & 418 & 147 & 885 \\
hematite & 54 & 93 & 32 & 179 \\
shell & 8 & 7 & 2 & 17 \\
organics & 4 & 1 & 5 & 10 \\
\hline Totals & 811 & 1336 & 358 & 2505 \\
\hline
\end{tabular}

*some sherds have multiple tempers

The majority of the sherds from the plain ware, utility ware, and fine wares from the Spradley site are from vessels fired in a reducing or low oxygen environment (68.4 percent) in an open pit fire; about 50 percent of these were cooled in the open air, leaving thin oxidized bands along one or both outer edges of the sherd core. Only 21.5 percent of the sherds are from vessels that were fired in an oxidizing or high oxygen fire, and another 8.0 percent are from vessels that were incompletely oxidized during firing. Finally, 1.9 percent have evidence in sherd cores of smudging, sooting, and/or refiring. 
The ceramic vessels at the Spradley site tend to be thin-walled, with mean rim sherd thickness ranging from $5.6 \mathrm{~mm}$ (plain ware), $6.7 \mathrm{~mm}$ (utility ware), and $5.6 \mathrm{~mm}$ for the fine wares. Body wall thickness across all three wares ranges from $6.0-7.3 \mathrm{~mm}$, with the body wall thickness of utility ware vessels about 20 percent thicker than the fine wares. Measured base sherds have a mean thickness of $10.3 \mathrm{~mm}$.

Vessel forms include jars (among the utility wares), as well as bottles, bowls, carinated bowls (including globular carinated bowls), and vessels with rim peaks, probably compound bowls. Rim sherds tend to be direct or freestanding $(n=169)$ and another 49 have an everted rim. Lips are primarily rounded $(n=200)$, but others have a flat lip $(n=18)$, and others have exterior folded lips $(n=78)$.

There are a number of decorative classes in the utility wares (Table 13). Sherds with brushed marks (or brushed marks with either associated incised or punctated decorative elements) dominate these wares, accounting for 71 percent of the utility wares. About 48 percent of the utility ware rim sherds have brushing marks (Figure 20). A number of the brushed-incised sherds are from Spradley Brushed-Incised vessels that have parallel brushing with overlapping straight incised lines opposed or perpendicular to the brushing (Figure 21).

Table 13. Utility ware decorative classes from the Spradley site.

\begin{tabular}{|c|c|c|c|c|}
\hline Class & $\operatorname{Rim}$ & Body & Base & $\mathrm{N}$ \\
\hline Appliqued & 2 & 7 & - & 9 \\
\hline Appliqued-Brushed & - & 3 & - & 3 \\
\hline $\begin{array}{l}\text { Appliqued-Brushed- } \\
\text { Punctated }\end{array}$ & - & 18 & - & 18 \\
\hline Appliqued-Punctated & 1 & 9 & - & 9 \\
\hline Brushed & 83 & 2101 & 2 & 2186 \\
\hline Brushed-Incised & 1 & 117 & - & 118 \\
\hline Brushed-Punctated & 4 & 19 & - & 23 \\
\hline Grooved & 1 & 6 & - & 7 \\
\hline Grooved-Brushed & 1 & - & - & 1 \\
\hline Incised & 33 & 477 & - & 510 \\
\hline Incised-Punctated & 10 & 50 & - & 60 \\
\hline Lip Notched & 4 & - & - & 4 \\
\hline Neck Banded & 2 & 1 & - & 3 \\
\hline Neck Banded-Punctated & 1 & - & - & 1 \\
\hline Neck Banded-Brushed & 1 & - & - & 1 \\
\hline Pinched & 4 & 12 & - & 16 \\
\hline Punctated & 33 & 226 & - & 259 \\
\hline Totals & 181 & 3046 & 2 & 3229 \\
\hline
\end{tabular}




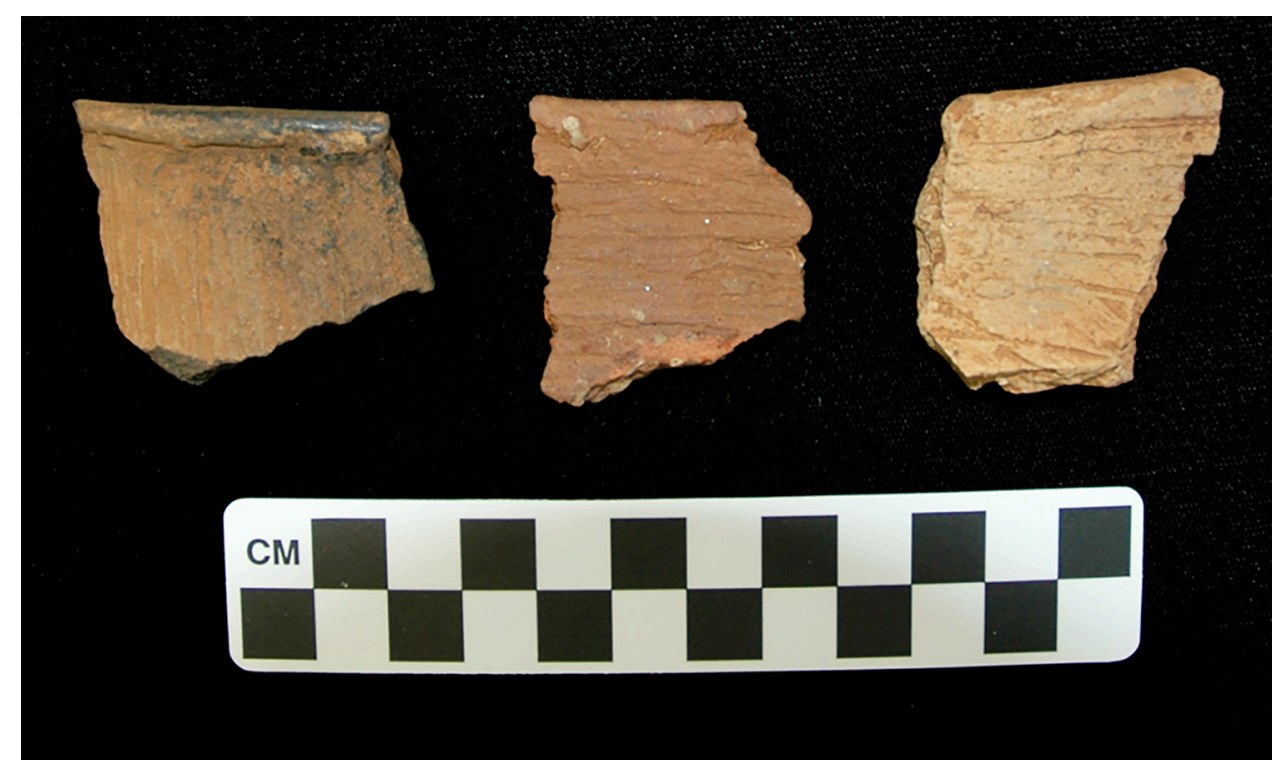

Figure 20. Brushed rim sherds from the Spradley site.

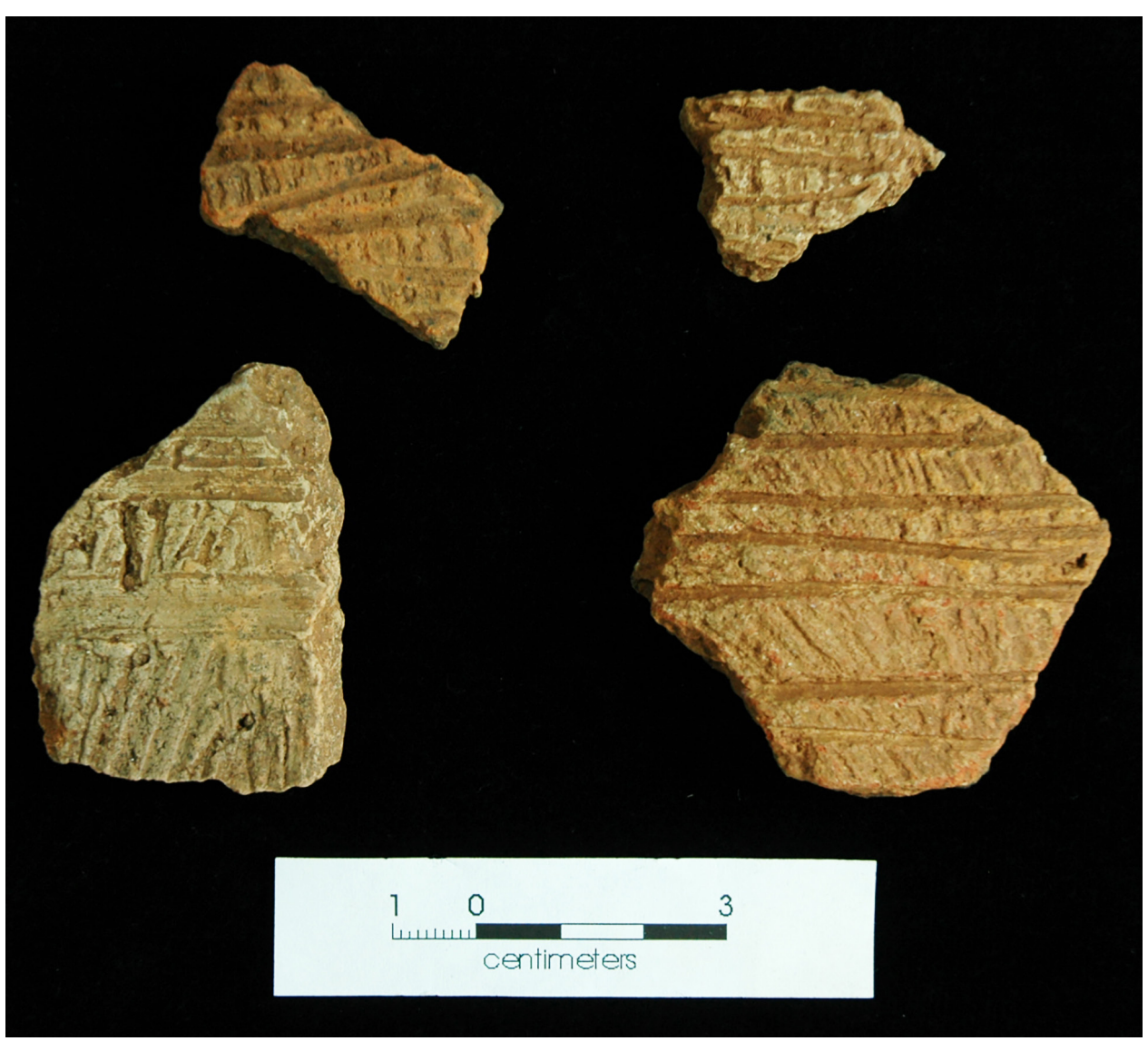

Figure 21. Spradley Brushed-Incised body sherds from the Spradley site. 
The rims with incised decorations have horizontal or diagonal lines (Figure 22), as well as vertical or opposed incised lines; these are probably from Maydelle Incised vessels (see Suhm and Jelks 1962:Plate 52). Incised body sherds have curvilinear, straight, or parallel incised lines, as well as cross-hatched, opposed, and perpendicular elements. The incised-punctated sherds have horizontal and/or diagonal incised lines with rows of tool punctations, as well as sherds with curvilinear incised zones filled with punctations(Figure 23); these tend to occur beneath the lip and above the incised decorations. Incised lines also form zones filled with punctations. The few pinched sherds are likely all from Killough Pinched vessels (see Suhm and Jelks 1962:Plate 46). The punctated sherds have rows of punctations made with different kinds of tools on vessel rims and body sherds (Figure 24).

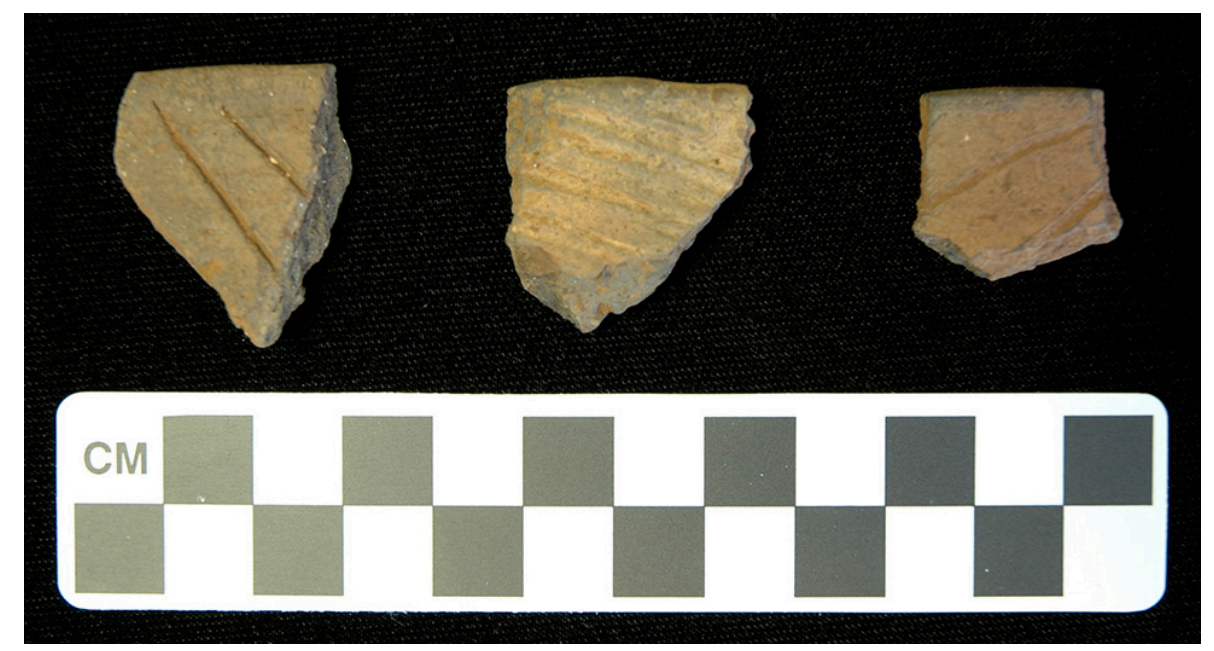

Figure 22. Incised rim sherds from the Spradley site.

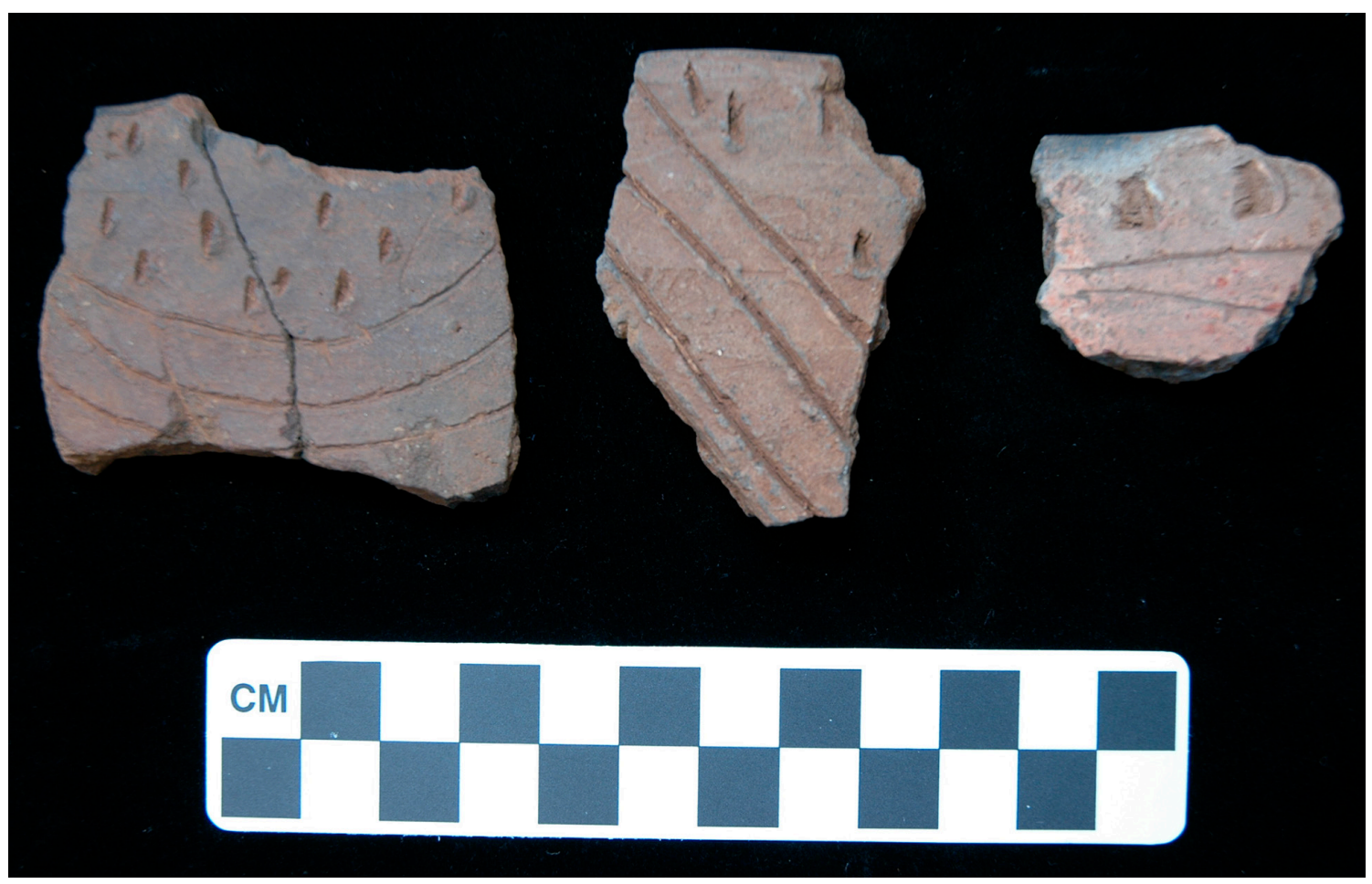

Figure 23. Sherds with incised-punctated decorative elements from the Spradley site. 


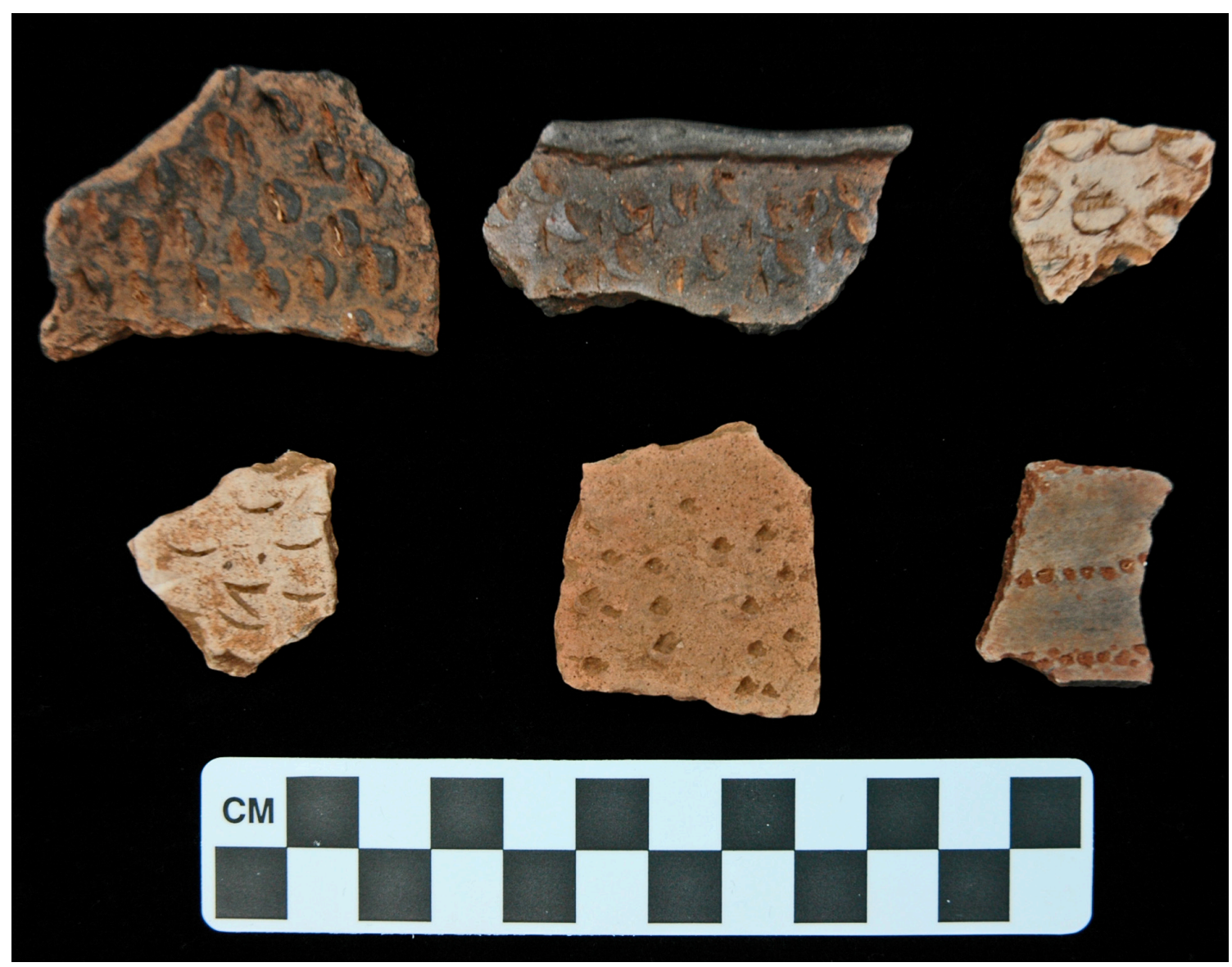

Figure 24. Range of punctated rim and body sherds from the Spradley site.

Sherds with appliqued elements account for slightly more than 1 percent of the utility ware sherds. These have appliqued ridge and fillet elements. Only 0.2 percent of the sherds, from Lindsey Grooved vessels, have broad grooved lines as a decorative element.

Patton Engraved is the dominant fine ware type at the Spradley site. These sherds have engraved lines with various orientations that have tick marks on the lines, usually excised tick marks, but also linear tick marks (Figure 25). Table 14 lists the decorative elements on Patton Engraved sherds from the site. 


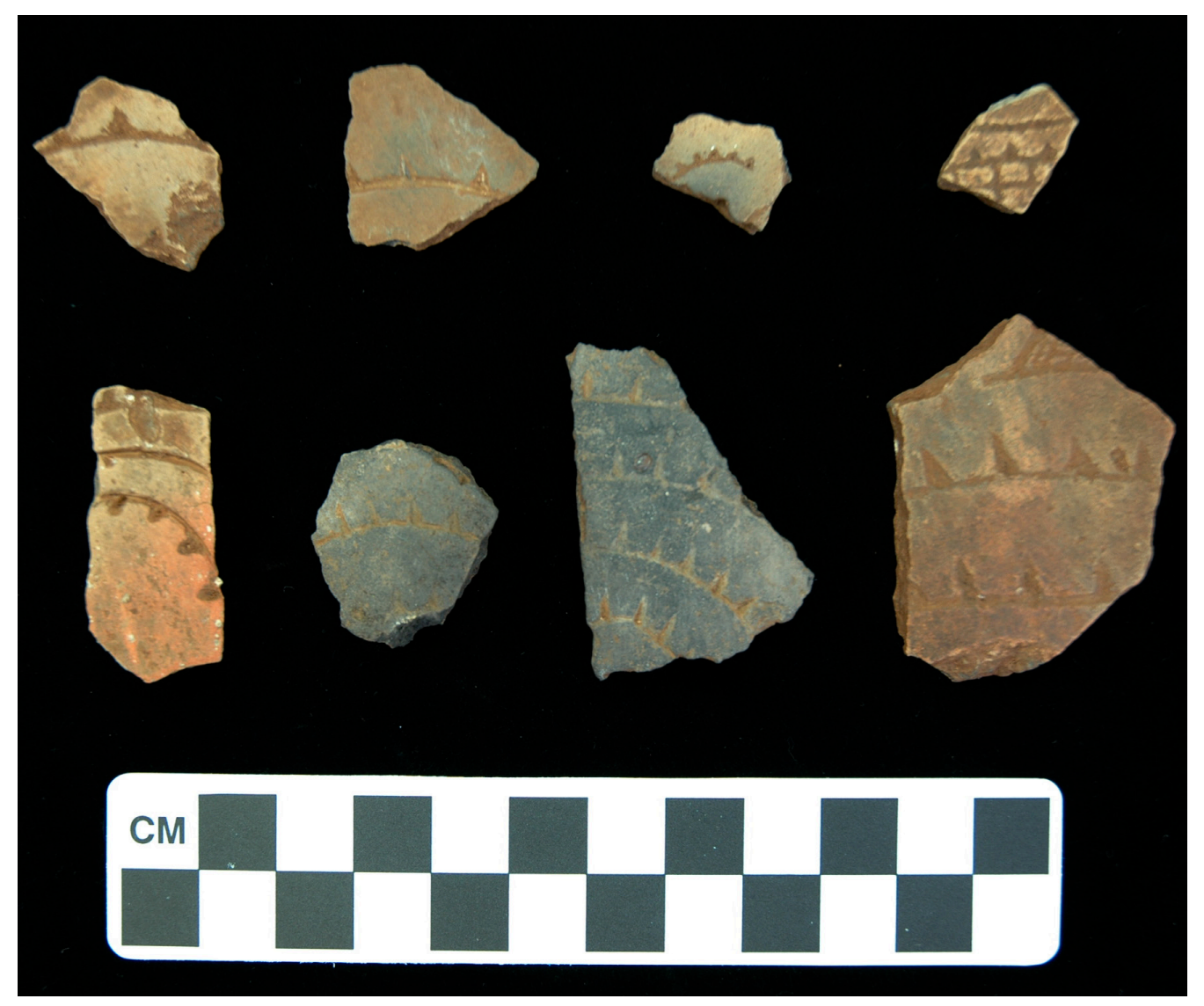

Figure 25. Patton Engraved body sherds from the Spradley site.

Table 14. Patton Engraved decorative elements on sherds from the Spradley site.

\begin{tabular}{|c|c|c|c|}
\hline Decorative element & Rim & Body & $\mathrm{N}$ \\
\hline $\begin{array}{l}\text { cross-hatched engraved el. and parallel engraved lines with } \\
\text { triangular tick marks }\end{array}$ & - & 1 & 1 \\
\hline curvilinear engraved el. with triangular tick marks & - & 3 & 3 \\
\hline curvilinear engraved line with triangular tick marks & - & 19 & 19 \\
\hline $\begin{array}{l}\text { curvilinear engraved lines and straight engraved line } \\
\text { with triangular tick marks }\end{array}$ & - & 1 & 1 \\
\hline curvilinear engraved lines, one with linear tick marks & - & 1 & 1 \\
\hline curvilinear engraved lines, one with triangular tick marks & - & 2 & 2 \\
\hline curvilinear engraved lines with triangular tick marks & - & 6 & 6 \\
\hline diagonal line with downward-pointing triangular tick marks & 1 & - & 1 \\
\hline engraved element with linear tick marks & 1 & - & 1 \\
\hline engraved element with triangular tick marks & 2 & 5 & 7 \\
\hline engraved line with linear tick marks & - & 2 & 2 \\
\hline engraved line/lines with triangular tick marks & - & 18 & 18 \\
\hline slanted scroll with triangular tick marks & 1 & - & 1 \\
\hline $\begin{array}{l}\text { horizontal engraved line with downward-pointing triangular } \\
\text { tick marks }\end{array}$ & 9 & - & 9 \\
\hline horizontal engraved line with linear tick marks & 1 & - & 1 \\
\hline
\end{tabular}


Table 14. Patton Engraved decorative elements on sherds from the Spradley site, cont.

\begin{tabular}{|c|c|c|c|}
\hline Decorative element & $\operatorname{Rim}$ & Body & $\mathrm{N}$ \\
\hline horizontal engraved line/lines with triangular tick mark & 3 & - & 1 \\
\hline horizontal engraved lines, one with triangular tick marks & 1 & - & 1 \\
\hline horizontal engraved lines with large excised triangles & 1 & - & 1 \\
\hline $\begin{array}{l}\text { horizontal engraved lines with triangular tick marks facing each } \\
\text { other }\end{array}$ & 7 & - & 7 \\
\hline $\begin{array}{l}\text { horizontal engraved line with triangular tick marks and diagonal } \\
\text { engraved lines }\end{array}$ & - & 1 & 1 \\
\hline $\begin{array}{l}\text { horizontal engraved lines with upward-pointing triangular tick } \\
\text { marks }\end{array}$ & - & 1 & 1 \\
\hline opposed engraved lines, one with triangular tick marks & 1 & 1 & 2 \\
\hline opposed engraved lines with triangular tick marks & - & 1 & 1 \\
\hline parallel engraved lines with triangular tick marks & - & 9 & 9 \\
\hline $\begin{array}{l}\text { parallel engraved lines with triangular tick marks facing each } \\
\text { other }\end{array}$ & - & 1 & 1 \\
\hline straight engraved line with large triangular tick marks & - & 1 & 1 \\
\hline straight engraved line with linear tick marks & - & 1 & 1 \\
\hline straight engraved line with triangular tick marks & - & 22 & 22 \\
\hline straight engraved line with triangular tick marks and parallel & - & 1 & 1 \\
\hline $\begin{array}{l}\text { straight engraved line with triangular tick marks with white } \\
\text { pigment }\end{array}$ & - & 1 & 1 \\
\hline Totals & 28 & 98 & 126 \\
\hline
\end{tabular}

The frequency of curvilinear, horizontal, and parallel engraved lines with tick marks (see Figure 25) suggests that var. Freeman, var. Allen, and var. Fair of Patton Engraved are present in the Spradley site fine wares (see Perttula 2011:Figure 6-66a-d). Patton Engraved, var. Freeman is the earliest of the varieties, likely dating to the late $17^{\text {th }}$ century, while var. Allen is a slightly later Patton Engraved variety, perhaps dating from the early $18^{\text {th }}$ century (Perttula 2011:286).

Two rim sherds may be from either Poynor Engraved, var. Freeman or Patton Engraved, var. Freeman vessels. They have horizontal engraved lines with triangular tick marks and vertical dividers/ brackets (see Perttula 2011:Figure 6-64h and Figure 6-66c).

Hume Engraved sherds in the assemblage (Figure 26b, e-f) have engraved ladder (var. Hume) and hatched engraved triangle elements (var. Allen) (see Perttula 2011:Figure 6-6e-f). Both of these varieties are found primarily in Allen phase contexts in the Neches-Angelina river basins (Perttula 2011:286). The one Keno Trailed, var. unspecified body sherd has broad curvilinear trailed lines. King Engraved sherds have cross-hatched engraved zones, sometimes with horizontal brushing on the vessel body. Finally, there are four sherds that compare favorably to Poynor Engraved in having cross-hatched elements, engraved divider elements, and engraved elements with hatched triangles (see Perttula 2011:Figure 6-64b, e, h). 


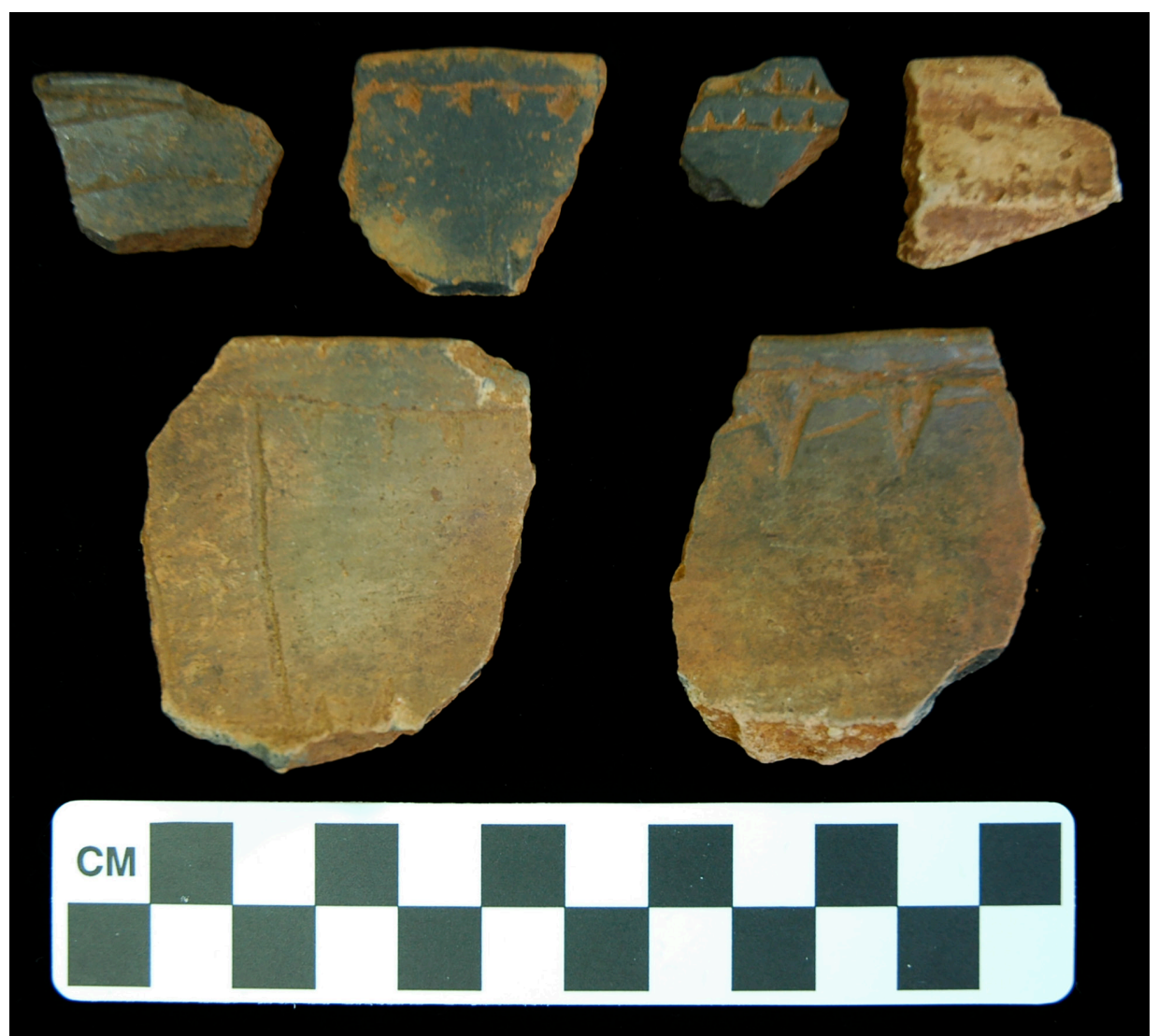

Figure 26. Patton Engraved and Hume Engraved sherds from the Spradley site: a, c-d, Patton Engraved; b, e-f, Hume Engraved.

\section{Ceramic Comparisons between certain Historic Caddo Sites} in Nacogdoches County, Texas: Spradley (41NA206), Henry M. (41NA60), and Deshazo (41NA27)

The Henry M., Deshazo, and Spradley sites are three of the better and recently studied Historic Caddo ceramic assemblages in East Texas (see Fields 1995; Middlebrook and Perttula 2008; Perttula et al. 2010; Marceaux 2011). All three sites are in Nacogdoches County (see Middlebrook 2007:Figure 1), Henry M. and Deshazo on Bayou Loco, and Spradley on Lanana Creek. How do these sites compare to each other with respect to the decorative classes present in the utility wares and fine wares? All three sites are dominated by brushed utility wares (Table 15). At Spradley, however, brushed pottery comprises 52.6 percent of the decorated sherds compared to 72.7-84.2 percent of the decorated sherds from Henry M. and Deshazo. Incised, punctated, and incised-punctated decorative classes, moreover, are also abundant in the Spradley ceramic assemblage (20.0 percent), but much rarer in the Henry M. and Deshazo utility wares (3.6 to 7.2 percent). 
Table 15. Decorative classes in the utility ware and fine ware ceramics.

\begin{tabular}{llll}
\hline Decoration & Spradley & Henry M. & Deshazo* \\
\hline Utility Wares & & & \\
Brushed & $52.6+$ & $\underline{\mathbf{2 . 3}}$ & $\underline{\mathbf{4 4 . 2}}$ \\
Brushed-incised & $\underline{\mathbf{2 . 8}}$ & 0.3 & 0.7 \\
Brushed-appliqued & 0.5 & Trace & 0.2 \\
Brushed-punctated & 0.5 & 0.1 & 0.9 \\
Grooved & 0.2 & $\underline{\mathbf{2 . 4}}$ & 0.2 \\
Neck banded & 0.1 & 0.1 & Trace \\
Appliqued & 0.2 & Trace & 0.3 \\
Appliqued-punctated & 0.2 & - & 0.5 \\
Incised & $\underline{\mathbf{1 2 . 4}}$ & 5.2 & 2.0 \\
Punctated & $\underline{\mathbf{6 . 2}}$ & 1.7 & 1.3 \\
Incised-punctated & $\underline{\mathbf{1 . 4}}$ & 0.3 & 0.3 \\
Pinched & 0.4 & - & Trace \\
Lip notched & 0.1 & - & Trace \\
Fine wares & & & 8.7 \\
Engraved & & & - \\
Engraved-brushed & $\underline{\mathbf{2 2 . 3}}$ & 13.0 & 0.1 \\
Engraved-punctated & - & 0.8 & Trace \\
Trailed & - & - & 23,448 \\
\hline No. of decorated sherds & $<0.1$ & - & 2132 \\
\hline
\end{tabular}

+=percentage; *see Fields (1995) and Marceaux (2011)

Fine wares-especially from Patton Engraved vessels - comprise between 13.8 percent and 22.3 of the decorated sherds at the Spradley and Henry M. sites (see Table 15), but only 8.8 percent at the Deshazo site, suggesting that fine wares were equally abundant and regularly accessible to the inhabitants at both of these Historic Caddo sites, but less so at Deshazo.

Henry M. and Deshazo ceramics are primarily grog-tempered (83-90.4 percent) (Table 16). Bonetempered pottery, conversely, is much more abundant at the Spradley site, suggesting the existence of a different tradition of ceramic manufacture and technology there when compared to the wide-spread use of grog temper at the two Bayou Loco sites. Shell-tempered pottery is rare in each of these assemblages (less than 0.7 percent). Later (ca. post-1750) Caddo ceramic assemblages in the Angelina River basin have higher percentages of shell-tempered wares: 5.4 percent at 41NA223 (ca. 1750-1800, Perttula 2008a) and 8.3 percent at the D'Ortolan site (41NA299, ca. 1790-1820, Perttula 2008b). 
Table 16. Temper comparisons between the three Historic Caddo sites.

\begin{tabular}{llll}
\hline Temper & Spradley & Henry M. & Deshazo \\
\hline bone-tempered & $35.4 \%$ & $9.2 \%$ & $17.0 \%$ \\
shell-tempered & $0.7 \%$ & $0.4 \%$ & - \\
grog-tempered & $56.6 \%$ & $90.4 \%$ & $83 \%$ \\
\hline
\end{tabular}

We can extend the ceramic comparisons to a broader part of Nacogdoches County (Table 17), employing several categories of decoration/utility ware metrics originally proposed by Middlebrook (2007:Table 1) as a means to differentiate contemporaneous ceramic assemblages, and also perhaps to distinguish different Caddo groups and communities living in the area. In Table 17, selected assemblages are used that have more than 196 total sherds, and list them by drainage. The use of ceramic metrics (i.e., ratios of various categories of decorated sherds as well as use of different tempers) has become an important analytical tool in assessing the stylistic similarity of different assemblages of Late Caddo and Historic Caddo ceramic assemblages in East Texas (see especially Marceaux 2011; Perttula 2016). Recent compilations of ceramic vessel sherd assemblages from sites in the Neches, Angelina, and Sabine River basins that focus on the distinctive character of Caddo utility ware vessel decorations in Hasinai Caddo archaeological sites, particularly the common use of brushing as a decorative method, and the ratio of brushed to other wet paste decorated sherds.

Table 17. Ceramic comparisons with selected other Historic Caddo sites in Nacogdoches County, Texas.

\begin{tabular}{llll}
\hline Site* & \% Brushed ${ }^{* *}$ & Brushed/Plain & \% Brushed/Brushed + Plain \\
\hline Lanana Creek sites & & & \\
41NA206 & 26.6 & 0.50 & 33.4 \\
41NA223 & 18.1 & 0.32 & 24.2 \\
Angelina River sites and Bayou Loco & & \\
41NA6 & 65.1 & 4.61 & 82.2 \\
41NA15 & 54.0 & 4.29 & 81.1 \\
41NA54 & 70.2 & 3.8 & 79.0 \\
Bayou Loco sites & & & 54.7 \\
41NA21 & 46.2 & 1.21 & 57.3 \\
41NA22 & 48.7 & 1.34 & 53.5 \\
41NA23 & 43.0 & 1.15 & 74.3 \\
41NA27 & 66.1 & 2.9 & 73.8 \\
41NA60 & 59.8 & 2.8 & 84.5 \\
41NA111 & 69.4 & 5.44 & 51.8 \\
Legg Creek & 34.1 & 1.07 & 10.7 \\
41NA44 & & & \\
Attoyac Bayou & 7.2 & 0.12 & \\
41NA67 & & &
\end{tabular}

* Except for 41NA223, the sherd data from the other listed sites is from Middlebrook (2007:Table 1).

$* * \%$ Brushed is the percentage of all sherds with brushing as the only surface treatment; Brushed/Plain is the ratio of brushed sherds to plain or undecorated sherds; and \% Brushed/Brushed + Plain is the percentage of the sherds with brushing compared to all the sherds in a collection that do not have "more elaborate decorative styles such as incised, engraved, or punctated" (Middlebrook 2007:101). 
An inspection of Table 17 indicates the following:

- The closest ceramic comparisons between the Spradley site and the other known Nacogdoches County historic Caddo sites is with 41NA223, also on Bayou Lanana;

- Bayou Loco and Angelina River sites are dominated by brushed utility wares. In the case of the Bayou Loco sites, they can be divided into two groups based on the relative proportion of brushed wares, one group with proportions ranging from 43-48.7 percent and the other with proportions between 59.8-69.4 percent (see Table 17); and

- the Lanana Creek Caddo sites (including the Spradley site), Legg Creek sites, and Attoyac Bayou sites are part of a different local ceramic tradition, where brushed pottery is much less important in the utility wares and in the overall ceramic assemblage, particularly in Caddo sites on Attoyac Bayou and Lanana Creek (see Table 17).

Table 17 makes clear that there are distinct spatial groupings of Allen phase sites in Nacogdoches County. Table 18 reshuffles the sites to regroup them by proportional similarity in the percentages and ratios expressed in the same ceramic attributes employed in Table 17, irrespective of stream drainage, leading to the recognition of five groupings: Group I on Lanana Creek, Group II on the lower Bayou Loco, Group III on the upper part of Bayou Loco and other streams draining into the Angelina River, Group IV includes sites on Bayou Loco and Legg Creek, and a single site near the confluence of Attoyac Bayou and the Angelina River (Figure 27).

Table 18. Groups I-V of Historic Caddo Ceramic Assemblages.

\begin{tabular}{|c|c|c|c|}
\hline Site* & $\%$ Brushed $* *$ & Brushed/Plain & $\%$ Brushed/Brushed + Plain \\
\hline \multicolumn{4}{|c|}{ Group I: Lanana Creek sites } \\
\hline 41NA206 & 26.6 & 0.50 & 33.4 \\
\hline 41NA223 & 18.1 & 0.32 & 24.2 \\
\hline \multicolumn{4}{|c|}{ Group II: Bayou Loco } \\
\hline 41NA60 & 59.8 & 2.8 & 73.8 \\
\hline 41NA27 & 66.1 & 2.9 & 74.3 \\
\hline \multicolumn{4}{|c|}{ Group III: Angelina River and Bayou Loco } \\
\hline 41NA15 & 54.0 & 4.29 & 81.1 \\
\hline 41NA6 & 65.1 & 4.61 & 82.2 \\
\hline 41NA111 & 69.4 & 5.44 & 84.5 \\
\hline 41NA54 & 70.2 & 3.8 & 79.0 \\
\hline \multicolumn{4}{|c|}{ Group IV: Bayou Loco sites and Legg Creek } \\
\hline 41NA44 & 34.1 & 1.07 & 51.8 \\
\hline 41NA21 & 46.2 & 1.21 & 54.7 \\
\hline 41NA22 & 48.7 & 1.34 & 57.3 \\
\hline 41NA23 & 43.0 & 1.15 & 53.5 \\
\hline \multicolumn{4}{|c|}{ Group V: Attoyac Bayou } \\
\hline 41NA67 & 7.2 & 0.12 & 10.7 \\
\hline
\end{tabular}

**\% Brushed is the percentage of all sherds with brushing as the only surface treatment; Brushed/Plain is the ratio of brushed sherds to plain or undecorated sherds; and \% Brushed/Brushed + Plain is the percentage of the sherds with brushing compared to all the sherds in a collection that do not have "more elaborate decorative styles such as incised, engraved, or punctated" (Middlebrook 2007:101). 


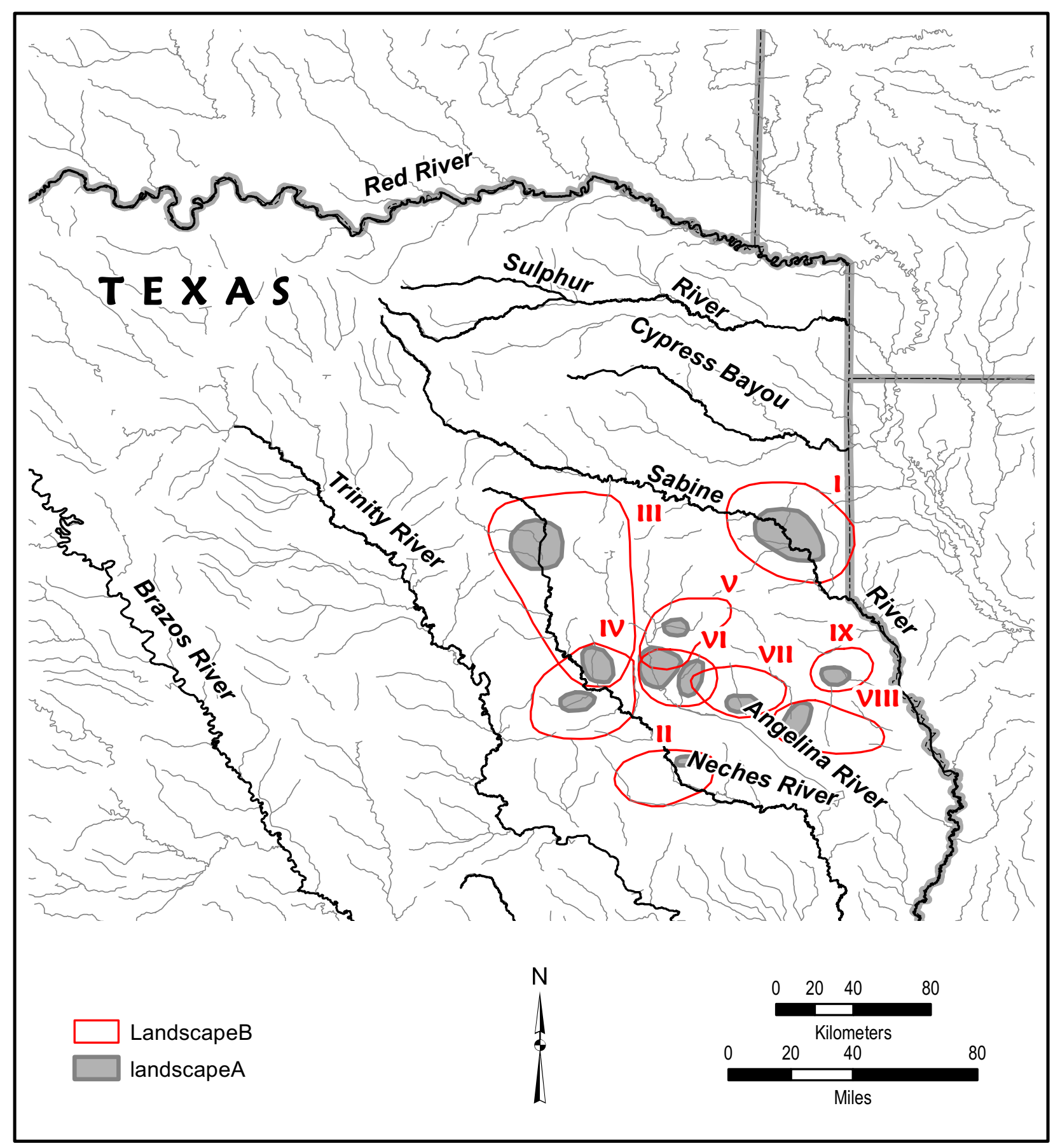

Figure 27. Location of Group I to Group V Historic Caddo ceramic assemblages in Nacogdoches County (after Middlebrook 2007:Figure 1). 
The most recent ceramic metric compilation is provided in Table 19. The Nadaco (I), lower Neches (II), and upper Neches (northern part of III) ceramic clusters and groups are also divergent from the remainder of the groups, the latter concentrated in the mid-Neches and Angelina River basins (Figure 28), as are the ceramic clusters in the Attoyac Bayou basin (VIII). The lower Neches and upper Neches groups have the highest proportion of brushed sherds in decorated sherd assemblages and the highest ratios of brushed to other wet paste sherds. The Group IV Neche II and Nabedache clusters are similar in proportions of brushed sherds and in brushed to other wet paste sherd rations, suggesting these spatially related sites are also closely related in cultural practices.

Table 19. Comparisons between East Texas Historic Caddo assemblages.

\begin{tabular}{llll}
\hline Areas & $\begin{array}{l}\text { Percent Brushed in } \\
\text { Decorated Sherds }\end{array}$ & $\begin{array}{l}\text { Brushed/ } \\
\text { Wet Paste }\end{array}$ & Cluster \\
\hline I, Nadaco, Sabine River & 64.8 & 1.95 & Nadaco \\
II, lower Neches & 90.8 & 11.38 & None Identified \\
III, Upper Neches & $82.7-88.1$ & $8.14-9.63$ & Upper Neches \\
III, Neche, I & 87.4 & 6.34 & Neche \\
& & & \\
IV, Neche, II & 81.3 & 6.74 & Neche \\
IV, Nabedache & 71.4 & 4.36 & Nabedache \\
& & & \\
V, Middle Angelina II & 70.0 & 2.30 & Legg Creek \\
V, Nasoni/East Fork Angelina & 66.8 & 3.08 & Nasoni \\
VI, Middle Angelina I & 84.7 & 6.71 & King Creek \\
VI, Bayou Loco I & 81.8 & 8.89 & Bayou Loco South \\
VII, Bayou Loco II & 60.9 & 1.86 & Bayou Loco North \\
VII, Bayou La Nana & 56.5 & 2.25 & Nacogdoche \\
VIII, Attoyac Bayou II & 50.0 & 1.72 & Attoyac \\
VIII, Attoyac Bayou I & 30.4 & 0.61 & Upper/Lower Attoyac \\
IX, Ais mission & 0.0 & 0.0 & Ais \\
\hline
\end{tabular}

lower Angelina: 41AG22

Ais mission: Corbin et al. 1980, 1990

Middle Angelina I: 41CE62, 41NA6, 41NA15

Middle Angelina II: 41NA44, 41NA54

Bayou La Nana: 4NA206 (Spradley)

Bayou Loco I: 41NA21, 41NA22, 41NA23, 41NA27 (Deshazo), 41NA60 (Henry M.), 41 NA111

Bayou Loco II:41NA183

Attoyac Bayou I: 41NA67, 41SA116

Attoyac Bayou II:41SA94

Ceramic groups V-VI represent the core of known Hasinai Caddo ceramic assemblages in the Angelina River basin (see Figure 28 and Table 19). Ceramic group V has been readily linked with the Nasoni Caddo, since Mission Nasoni (1716-1730) is one of the sites included in the Table 19 compilation. This group in turn is stylistically similar in its utility wares to mid-Angelina River basin sites on Legg Creek, while other mid-Angelina River basin sites (King Creek) are stylistically similar to both Bayou Loco and Bayou La Nana assemblages (see Figure 21 and Table 19). These latter groups may 


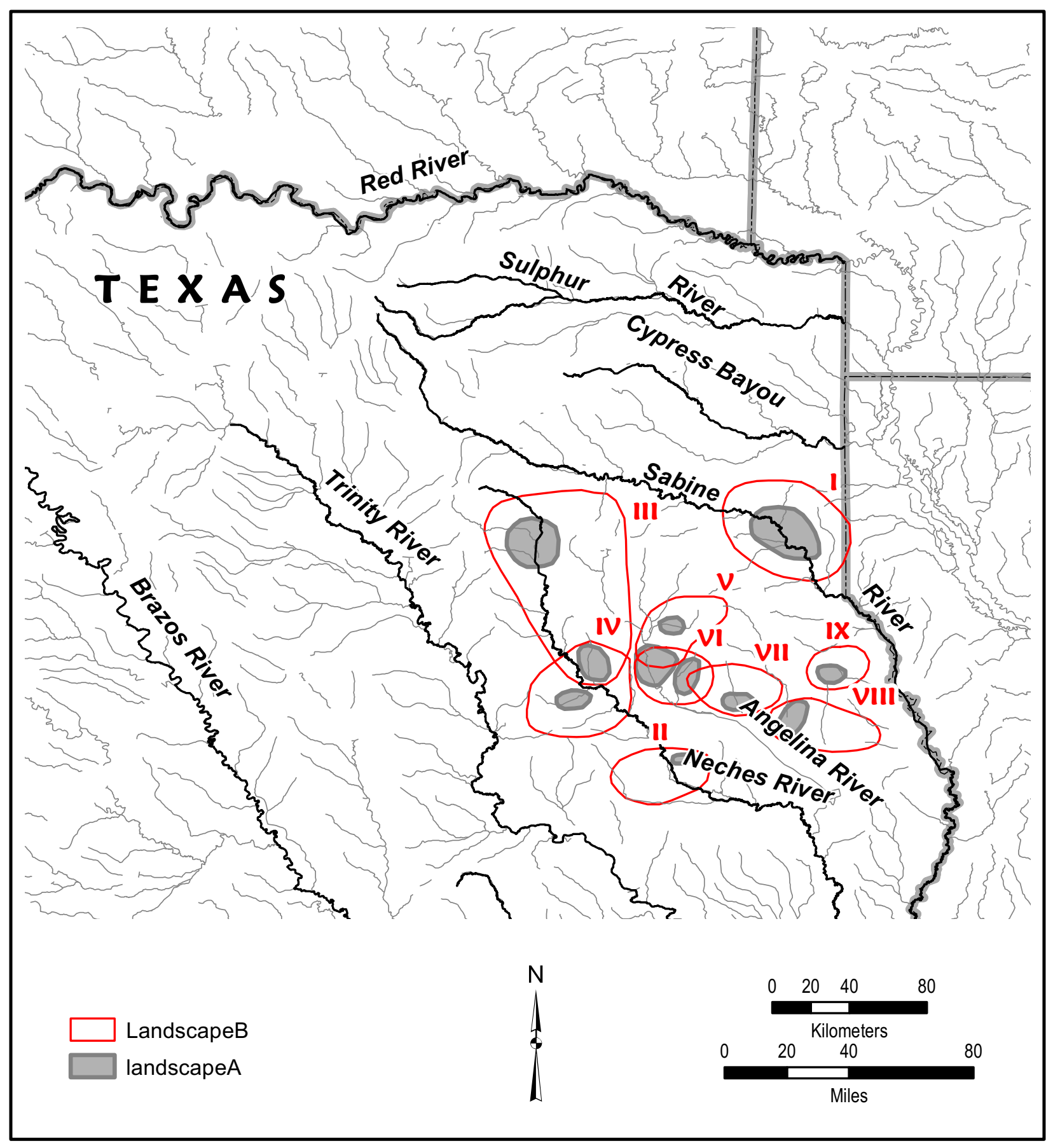

Figure 28. Spatial groupings of Historic Caddo and Historic Ais ceramic clusters I-IX in East Texas.

be affiliated with both Hainai and Nacogdoche Caddo groups living in this part of East Texas throughout the $18^{\text {th }}$ century, with the Spradley site occupation most closely affiliated with the Nacogdoche.

The Attoyac group (VIII) has much lower proportions of brushed sherds and more equitable brushed to other wet paste sherd ratios $(0.61-1.72)$ than the other groups. The ethnic affiliation of this group of sites is not known. 
What do these ceramic groups represent other than generally contemporaneous historic sites occupied by Caddo peoples? This ceramic sherd data from a number of sites and areas indicates that the utility wares of the East Texas Hasinai (and the Nadaco on the Sabine) can help identify specific groups/ communities of ceramic practice, and if they can be linked confidently to specific Caddo groups known through ethnographic and historic records, then archaeologists are in a much better position to determine the direction of cultural and ceramic change through time, particularly concerning what happened to these groups from pre-contact times through much of the 18th century, and perhaps beyond. It is our opinion, then, that these group represent different but clearly related and interacting social groups or communities of Caddo peoples living in the Angelina River basin in historic times (Corbin 2007; Perttula 2016).

\section{Pipes}

One ceramic pipe sherd from an elbow pipe was recovered in N61-W49, level 3. This is a bonetempered bowl/distal stem sherd that has $6+$ rows of small circular punctations above the flat bowl base (Figure 29). Napoleon (1995:Figure 53h) illustrates a similar decorated pipe from the Deshazo site (41NA13), and pipes of this style have also been reported from the upper Neches River basin (Perttula 2011:Figure 6-24d). Jackson (1933:75) refers to these as Neches pipes.

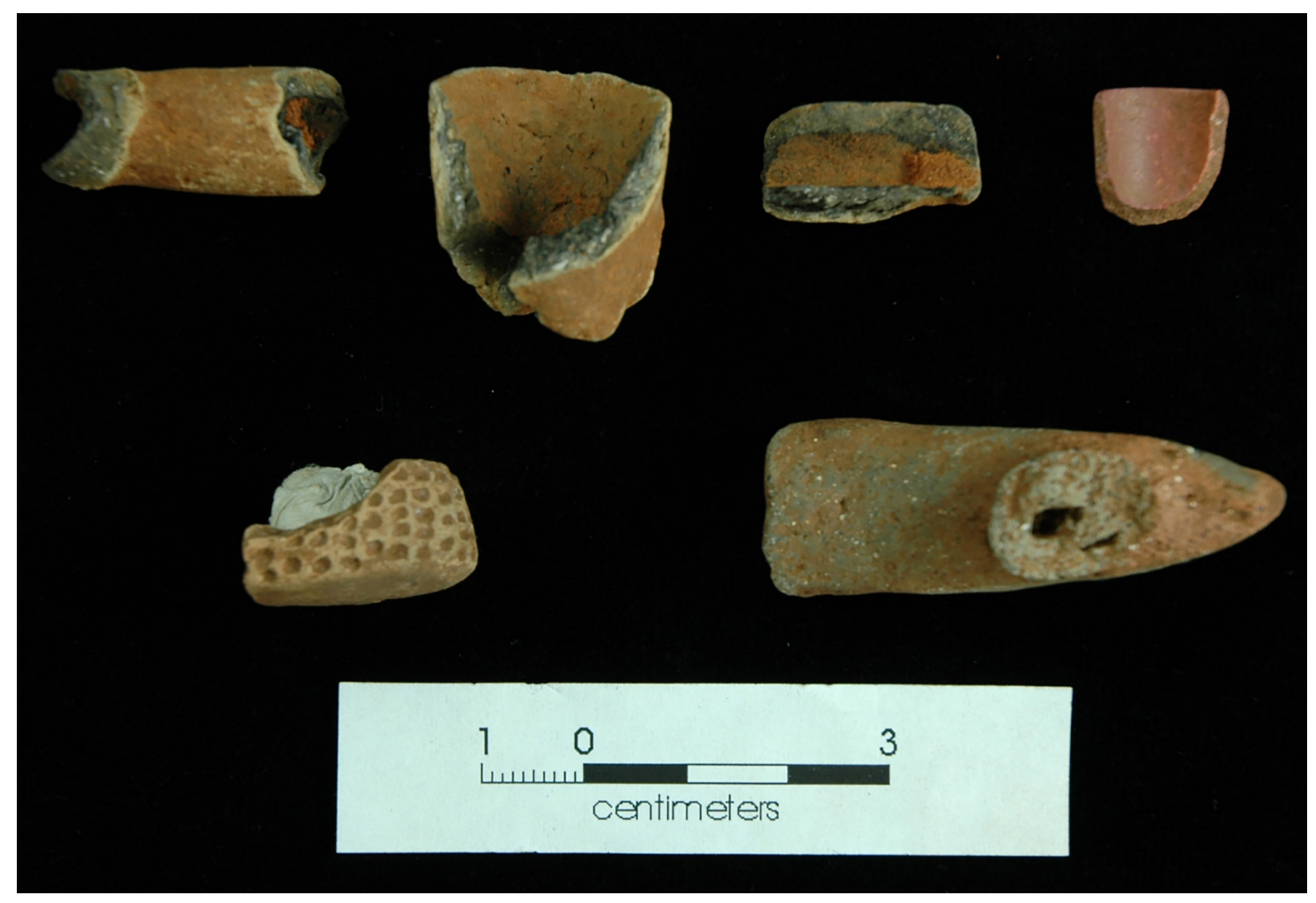

Figure 29. Punctated elbow pipe sherd from the Spradley site. 


\section{Woodland Period, Mossy Grove Ceramic Artifacts, by Timothy K. Perttula}

There are 40 body sherds from sandy paste Goose Creek Plain, var. unspecified vessels (see Story 1990) in the assemblage from the Spradley site (Table 20). These are part of the Woodland period, Mossy Grove culture occupation of the site that occurred sometime between ca. 500 B.C.-A.D. 800.

Table 20. Sandy paste ceramic sherds from the Spradley site.

\begin{tabular}{|c|c|c|}
\hline Lot No. & Provenience & Description \\
\hline 138 & N75-W65, lv. 2 & plain body sherd, fired and cooled in a reducing environment \\
\hline 139 & N75-W63, lv. 2 & plain body sherd, fired and cooled in an oxidizing environment \\
\hline 142 & N58-W39, lv. 1 & plain body sherd, fired and cooled in a reducing environment \\
\hline 182 & N75-W65, lv. 3 & plain body sherd, fired and cooled in an oxidizing environment \\
\hline 184 & N75-W63, lv. 3 & plain body sherd, incompletely oxidized during firing \\
\hline 315 & N73-W52, lv. 4 & plain body sherd, fired and cooled in an oxidizing environment \\
\hline 326 & N61-W48, lv. 3 & plain body sherd, fired and cooled in a reducing environment \\
\hline 331 & N62-W47, lv. 4 & plain body sherd, fired and cooled in a reducing environment \\
\hline 371 & N76-W63, lv. 3-4 & plain body sherd, fired and cooled in a reducing environment \\
\hline 419 & N65-W59, lv. 4 & plain body sherd, incompletely oxidized during firing \\
\hline 447 & N0-W20, lv. 3 & plain body sherd, fired and cooled in a reducing environment \\
\hline 489 & N20-W50, lv. 1 & plain body sherd, fired and cooled in an oxidizing environment \\
\hline 518 & N20-W26, lv. 1 & plain body sherd, fired and cooled in a reducing environment \\
\hline 543 & N10-W22, lv. 1 & plain body sherd, fired and cooled in a reducing environment \\
\hline 550 & N20-W25, lv. 5 & plain body sherd, fired and cooled in a reducing environment \\
\hline 550 & N20-W25, lv. 5 & plain body sherd, fired and cooled in a reducing environment \\
\hline 567 & N10-W22, lv. 5 & plain body, fired in a reducing environment and cooled in the open air \\
\hline 567 & N10-W22, lv. 5 & plain body sherd, fired and cooled in an oxidizing environment \\
\hline 589 & N11-W20, lv. 5 & plain body sherd, fired and cooled in an oxidizing environment \\
\hline 607 & $\mathrm{~N} 21-\mathrm{W} 15, \mathrm{lv} .1$ & plain body sherd, fired and cooled in a reducing environment \\
\hline 611 & N21-W15, lv. 5 & $\begin{array}{l}\text { plain body sherd, fired and cooled in a reducing }(44-54 \mathrm{~cm} \mathrm{bs}) \\
\text { environment }\end{array}$ \\
\hline 616 & N25-W15, lv. 4 & $\begin{array}{l}\text { plain body sherd, fired in a reducing environment and cooled in the } \\
\text { open air }\end{array}$ \\
\hline 618 & N25-W15, lv. 5 & plain body sherd, fired and cooled in a reducing environment \\
\hline 622 & N25-W16, lv. 2 & plain body sherd, fired and cooled in a reducing environment \\
\hline 624 & N25-W16, lv. 3 & plain body sherd, fired and cooled in a reducing environment \\
\hline 634 & N25-W17, lv. 2 & $\begin{array}{l}\text { plain body sherd, fired in a reducing environment and cooled in the } \\
\text { open air }\end{array}$ \\
\hline 652 & N26-W16, lv. 1 & plain body sherd, incompletely oxidized during firing \\
\hline 656 & N26-W16, lv. 3 & $\begin{array}{l}\text { plain body, opposed suspension holes, fired in a reducing } \\
\text { environment and cooled in the open air }\end{array}$ \\
\hline 656 & N26-W16, lv. 3 & plain body, fired and cooled in a reducing environment \\
\hline 663 & N26-W15, lv. 2 & plain body sherd, incompletely oxidized during firing \\
\hline 666 & N26-W15, lv. 3 & plain body sherd, sooted/smudged \\
\hline 666 & N26-W15, lv. 3 & plain body sherd, fired and cooled in a reducing environment \\
\hline 666 & N26-W15, lv. 3 & 5 plain body sherds, incompletely oxidized during firing \\
\hline 688 & N80-W60, lv. 6 & $\begin{array}{l}\text { plain body sherd, fired in a reducing environment and cooled in the } \\
\text { open air }\end{array}$ \\
\hline 694 & N61-W51, lv. 6 & $\begin{array}{l}2 \text { plain body sherds, } 1 \text { incompletely oxidized during firing, } \\
1 \text { sooted/smudged }\end{array}$ \\
\hline
\end{tabular}


The low density of sherds covers a ca. 80 x $50 \mathrm{~m}$ area (ca. 1 acre) on the landform, from N0 to N80 and $\mathrm{W} 15$ to $\mathrm{W} 65$, and occur in each arbitrary level, from $0-60 \mathrm{~cm}$ bs. About 70 percent of the sherds are from units excavated in the southeastern portion of the grid, on an upland toe slope (see Figure 3 ) that slopes to the south, particularly in units N26-W15 and W16. The sherds are from at least five separate vessels, based on patterns of firing observed in the sherd core sections. Approximately 43 percent of the sherds are from vessels that were fired and cooled in a reducing or low oxygen environment. Another 25 percent were incompletely oxidized during the firing, and 15 percent were fired and cooled in an oxidizing or high oxygen environment. Five sherds (12.5 percent) were from vessels fired in a reducing environment and cooled in the open air. Finally, two sherds (5.0 percent) have sooted or smudged surfaces with a build up on charred and blackened materials on either one or both vessel surfaces.

The sherds are from vessels (probably jars) made with a non-tempered and locally available sandy clay. One vessel sherd in N26-W16 has two drilled suspension holes, indicating the vessel had been suspended during part of its use life.

\section{Summary and Synthesis of the Archaeological Findings from the Spradley Site}

The Spradley site (41NA206) is an important Native American archaeological site in the Bayou La Nana valley in Nacogdoches County in the East Texas Pineywoods. Bayou La Nana is a southwardflowing tributary to the Angelina River and merges with it about $15 \mathrm{~km}$ below the city of Nacogdoches, Texas. The site is best known for its late $17^{\text {th }}$-early $18^{\text {th }}$ century Historic Caddo period occupation, and the recovery of a number of European trade goods (Marceaux 2011) from habitation deposits, but the site was also occupied in Late Archaic (ca. 5000-2500 years B.P.), Woodland (ca. 2500-1150 years B.P.), and pre-A.D. 1400 Caddo periods. There are a number of other known Historic Caddo period settlements in Nacogdoches County, but most of these lie west and northwest of the Spradley site on other tributaries to the Angelina River.

The Spradley site was the scene of Stephen F. Austin State University (SFASU) Field School in 2001, 2003, and 2005. In this publication, we present the first comprehensive and detailed publication of both the lithic and ceramic artifacts recovered from the SFASU work at the Spradley site (see also Marceaux 2011).

The chipped stone tools from the Spradley site are dominated by arrow points and arrow point fragments $(n=70)$ and arrow point preforms $(n=12)$, as these comprise 75 percent of the tool assemblage. Also present are flake tools $(n=9)$, scrapers $(n=3)$, drills $(n=3)$, bifaces $(n=6)$, and dart points $(n=23)$. The identified arrow point and dart point types in the Spradley site assemblage indicate that it was used during Late Archaic (from ca. 2000 B.C.), Woodland, and pre-A.D. 1400 Caddo periods, as well as during the post-A.D. 1680 Historic Caddo period.

All of the dart points and dart point fragments are made from local lithic raw materials, almost exclusively (91 percent) from petrified wood. Five different dart points are present in the sample, including Gary ( $n=6)$, Kent ( $n=7)$, Godley $(n=1)$, Pontchartrain $(n=2)$, and Yarbrough $(n=)$; the Pontchartrain and Yarbrough dart points are of Late Archaic manufacture (ca. 5000-2500 years B.P.). The Gary, Godley, and Kent dart points are temporal diagnostics of the Woodland period (ca. 2500-1150 years B.P.) in this part of the Pineywoods.

Most of the arrow points are made on local lithic raw materials (83 percent)-among them petrified wood, quartzite, and local earth-toned cherts - but 17 percent are made on non-local cherts. One arrow point fragment is made from a bluish-green glass. 
The oldest arrow point styles in the arrow point assemblage include Friley $(n=5)$ and Scallorn $(n=1)$ points, and these may have been manufactured during late Woodland period times (ca. A.D. 700-900), when arrow points first began to be made in East Texas. These are followed by ca. A.D. 900-1200 arrow point styles - the Alba $(n=1)$ and Colbert $(n=2)$ types. There are two Bonham arrow points in the assemblage, and these are considered likely to date from ca. A.D. 1200-1400, indicating some use of the Spradley site during the Middle Caddo period. A Late Caddo arrow point type in the assemblage is the Bassett point ( $\mathrm{n}=3)$. The majority of the arrow points are thought to be associated with the principal Caddo occupation, one dating to early Historic period times. This includes 23 Perdiz points, cf. Perdiz points (with a rounded or flat contracting stem, often unifacially manufactured, $n=8$ ), cf. Turney (a triangular form with a slight concave base, $n=4$ ), and a single Cuney point. The one bluish-green glass arrow point fragment also is part of this component

On Historic Caddo sites in East Texas, triangular arrow point forms are predominant on sites from the Sabine River north to the Red River, while Perdiz, Cuney, and Turney arrow points occur almost exclusively on Historic Caddo sites in the Neches and Angelina river basins. At the Spradley site, Perdiz and cf. Perdiz points comprise 86 percent of the arrow points in the Historic Caddo period component, compared to 11 percent cf. Turney arrow points, and 3 percent that are Cuney points. The proportion of Perdiz points at the Spradley site is much more like the assemblage at the Deshazo site (96 percent of all the arrow points are Perdiz) than at the younger $18^{\text {th }}$ century Henry M. settlement, where only 8.3 percent are Perdiz points. Instead, at the Henry M. site, Turney and triangular Fresno points represent 67 percent of the arrow point assemblage, compared to only 1.6 percent at the Deshazo site and 11 percent at the Spradley site. Similarly, Cuney points are relatively abundant at Henry M., accounting for 25 percent of the assemblage, but only between 2.4-3 percent of the arrow points at the Desahzo and Spradley sites. In any events, these changes in arrow point styles suggest that there were rapid changes in the style and use of arrow points over time in the early years of contact between Europeans and Caddos in East Texas.

The arrow point preforms are ovoid to triangular-shaped, and generally they are unifacially flaked. The form of three of the preforms suggest they were preforms abandoned in the course of manufacturing either Perdiz or Bassett points.

The ground stone tools from the Spradley site include manos $(n=4)$, mano-pitted stones $(n=3)$, pitted stones $(n=2)$, and grinding slab fragments $(n=3)$. More than 90 percent of the ground stone tools are from excavation units in the northwestern part of the site.

There are 40 body sherds from sandy paste Goose Creek Plain, var. unspecified vessels (see Story 1990) in the assemblage from the Spradley site. These are part of the Woodland period Mossy Grove culture occupation of the site that occurred sometime between ca. 500 B.C.-A.D. 800. The sherds are from vessels (probably jars) made with a non-tempered and locally available sandy clay. One vessel sherd has two drilled suspension holes, indicating the vessel had been suspended during part of its use life.

The remaining 8806 sherds from the Spradley site excavations are from plain wares, utility wares, and fine wares. The plain wares comprise 52 percent of the collection; 37 percent of the rim sherds are from plain vessels. Sherds from utility ware vessels account for 37 percent of the assemblage, as well as 37 percent of the rims, and fine wares only account for 10.5 percent of the sherds from the site; fine ware rims represent, however, 25 percent of the assemblage. The assemblage has a plain/decorated sherd ratio of 1.12, a brushed to plain sherd ratio of 0.51 , and a brushed to other wet paste sherd ratio of 2.68. Brushed marks are present on 56.6 percent of the decorated sherds $(n=4156)$.

Sherds that compare favorably to a number of types known to occur on other Neches-Angelina River basin ancestral Caddo sites of late Frankston phase age (ca. A.D. 1560-1680), or date to the early part 
of the Allen phase (ca. A.D. 1680-1720), were identified in the Spradley site assemblage. They include: Hume Engraved, Keno Trailed, Killough Pinched, King Engraved, La Rue Neck Banded, Lindsey Grooved, Maydelle Incised, Patton Engraved, Poynor Engraved, a Poynor-Patton Engraved hybrid, and Spradley Brushed-Incised. Sherds from Patton Engraved and Spradley Brushed-Incised, both Allen phase types, are most common in the Spradley site assemblage.

The ceramic sherds from the Spradley site are from vessels tempered primarily with grog or burned bone. Grog occurs in 56 percent of the sherds, with the highest proportions in the utility wares (61 percent), while bone temper is present in 35 percent of the sherds; the highest proportion of bone use is in the fine wares ( 41 percent). Crushed hematite is present in 7 percent of the sherd sample, with the highest proportion of this temper present in the fine wares. Vessels made with shell temper are from nonlocally produced wares, likely made by Caddo groups along the Red River to the northeast in Northwest Louisiana and Southwest Arkansas. Only 0.7 percent of the sherds in the sample have shell temper.

The majority of the sherds from the plain ware, utility ware, and fine wares from the Spradley site are from vessels fired in a reducing or low oxygen environment in an open pit fire; about 50 percent of these were cooled in the open air. Only 21.5 percent of the sherds are from vessels that were fired in an oxidizing or high oxygen fire, and another 8.0 percent are from vessels that were incompletely oxidized during firing. Finally, 1.9 percent have evidence in sherd cores of smudging, sooting, and/or refiring. The ceramic vessels at the Spradley site tend to be thin-walled, with mean rim sherd thickness ranging from $5.6 \mathrm{~mm}$ (plain ware), $6.7 \mathrm{~mm}$ (utility ware), and $5.6 \mathrm{~mm}$ for the fine wares. Body wall thickness across all three wares ranges from 6.0-7.3 mm. Measured base sherds have a mean thickness of $10.3 \mathrm{~mm}$. Vessel forms include jars (among the utility wares), as well as bottles, bowls, carinated bowls (including globular carinated bowls), and vessels with rim peaks, probably compound bowls. Rim sherds tend to be direct or freestanding $(n=169)$ and another 49 have an everted rim. Lips are primarily rounded $(n=200)$, but others have a flat lip $(\mathrm{n}=18)$, and others have exterior folded lips $(\mathrm{n}=78)$.

There are a number of decorative classes in the utility wares. Sherds with brushed marks (or brushed marks with either associated incised or punctated decorative elements) dominate these wares, accounting for 71 percent of the utility wares. About 48 percent of the utility ware rim sherds have brushing marks. A number of the brushed-incised sherds are from Spradley Brushed-Incised vessels that have parallel brushing with overlapping straight incised lines opposed or perpendicular to the brushing. Patton Engraved is the dominant fine ware type at the Spradley site. These sherds have engraved lines with various orientations that have tick marks on the lines, usually excised tick marks, but also linear tick marks. The frequency of curvilinear, horizontal, and parallel engraved lines with tick marks suggests that var. Freeman, var. Allen, and var. Fair of Patton Engraved are present in the Spradley site fine wares. Patton Engraved, var. Freeman is the earliest of the varieties, likely dating to the late $17^{\text {th }}$ century, while var. Allen is a slightly later Patton Engraved variety, perhaps dating from the early $18^{\text {th }}$ century.

In comparison with other contemporaneous Allen phase sites in Nacogdoches County, namely the Henry M. and Deshazo sites, the Henry M. and Deshazo ceramics are primarily grog-tempered (83-90.4 percent). Bone-tempered pottery, conversely, is much more abundant at the Spradley site, suggesting the existence of a different tradition of ceramic technology and manufacture there when compared to the wide-spread use of grog temper at the two Bayou Loco sites. The closest ceramic comparisons between the Spradley site and other known Nacogdoches County historic Caddo sites is with 41NA223, also on Bayou Lanana; Bayou Loco and Angelina River sites are dominated by brushed utility wares. In the case of the Bayou Loco sites, they can be divided into two groups based on the relative proportion of brushed wares, one group with proportions ranging from 43-48.7 percent and the other with proportions between 59.8-69.4 percent; and the Lanana Creek Caddo sites (including the Spradley site), Legg Creek sites, 
and Attoyac Bayou sites are part of a different local ceramic tradition, where brushed pottery is much less important in the utility wares and in the overall ceramic assemblage, particularly in Caddo sites on Attoyac Bayou and Bayou La Nana Creek.

These findings make clear that there are distinct spatial groupings of Allen phase sites in Nacogdoches County: Group I on Bayou La Nana (including the Spradley site), Group II on the lower Bayou Loco, Group III on the upper part of Bayou Loco and other streams draining into the Angelina River, Group IV includes sites on Bayou Loco and Legg Creek, and a single site (41NA67) near the confluence of Attoyac Bayou and the Angelina River. Most ceramic groups represent the core of known Hasinai Caddo ceramic assemblages in the Angelina River basin, or linked with the Nasoni Caddo and Mission Nasoni (1716-1730). This group in turn is stylistically similar in its utility wares to midAngelina River basin sites on Legg Creek, while other mid-Angelina River basin sites (King Creek) are stylistically similar to both Bayou Loco and Bayou La Nana assemblages. These latter groups may be affiliated with both Hainai and Nacogdoche Caddo groups living in this part of East Texas throughout the $18^{\text {th }}$ century, with the Spradley site occupation most closely affiliated with the Nacogdoche. It is our opinion, that these defined ceramic group represent different but clearly related and interacting social groups or communities of Caddo peoples living in the Angelina River basin in historic times.

Further archaeological research concerning the Spradley site excavations remains to be completed. This includes the reporting of the excavations themselves, including the methods employed in the work, the character of the archaeological deposits in the different parts of the site, and a detailed presentation of identified features documented in the work. Also still to be completed is the analysis of the recovered lithic debris at the Spradley site, the plant and animal remains found in the archaeological deposits, and a full accounting and analysis of the $18^{\text {th }}$ century European artifacts found there. We hope that this work can be completed in short order, so that between this publication and future publications, a comprehensive discussion of the archaeological investigations at the early $18^{\text {th }}$ century Historic Caddo settlement at the Spradley site on Bayou La Nana in Nacogdoches County, Texas, will be available to professional and avocational archaeologists and the interested public.

\section{References Cited}

Anderson, D. G. and S. D. Smith

2003 Archaeology, History, and Predictive Modeling: Research at Fort Polk, 1972-2002. University of Alabama Press, Tuscaloosa.

Corbin, J. E.

2007 Cultural Diversity in the Southern Caddo Region. Journal of Northeast Texas Archaeology 26:1123.

Corbin, J. E., T. C. Alex, and A. Kalina

1980 Mission Dolores de los Ais. Papers in Anthropology No. 2. Stephen F. Austin State University, Nacogdoches.

Corbin, J. E., H. A. Brown, M. G. Canavan, and S. Toups

1990 Mission Dolores de los Ais (41SA25): San Augustine County, Texas, Archeological Investigations. Stephen F. Austin State University, Nacogdoches 
Fields, R. C.

1995 Analysis of Native-Made Ceramics. In The Deshazo Site, Nacogdoches County, Texas, Volume 2: Artifacts of Native Manufacture, edited by D. A. Story, pp. 173-232. Studies in Archeology 21. Texas Archeological Research Laboratory, The University of Texas at Austin.

Girard, J. S.

1995 The Chipped Stone Collection: Technological, Functional, and Typological Analyses. In The Deshazo Site, Nacogdoches County, Texas, Volume 2: Artifacts of Native Manufacture, edited by D. A. Story, pp. 33-156. Studies in Archeology 21. Texas Archeological Research Laboratory, The University of Texas at Austin.

Jackson, A. T.

1933 Some Pipes of East Texas. Bulletin of the Texas Archeological and Paleontological Society 5:6986.

Marceaux, P. S.

2011 The Archaeology and Ethnohistory of the Hasinai Caddo: Material Culture and the Course of European Contact. Ph.D. dissertation, Department of Anthropology, The University of Texas at Austin.

Middlebrook, T.

2007 A Survey of Historic Caddo Sites in Nacogdoches County. Journal of Northeast Texas Archaeology 26:99-115.

Middlebrook, T. and T. K. Perttula

2008 Archaeological Investigations at the Henry M. Site (41NA60): An Early Historic Caddo

Farmstead in Nacogdoches County, Texas. Journal of Northeast Texas Archaeology 28:13-20.

Napoleon, P. N.

1995 Analysis of Native-Made Ceramic Pipes. In The Deshazo Site, Nacogdoches County, Texas, Volume 2: Artifacts of Native Manufacture, edited by D. A. Story, pp. 157-171. Studies in Archeology 21. Texas Archeological Research Laboratory, The University of Texas at Austin.

Perttula, T. K.

2008a Analysis of the Historic Caddo Ceramics from 41NA223 in Downtown Nacogdoches, Nacogdoches County, Texas. Journal of Northeast Texas Archaeology 28:35-50.

2008b Caddo Ceramics from the D'Ortolan Site (41NA299). Journal of Northeast Texas Archaeology 28:21-23.

2011 The Ceramic Artifacts from the Lang Pasture Site (41AN38) and the Place of the Site within an Upper Neches River Basin Caddo Ceramic Tradition. In Archeological Investigations at the Lang Pasture Site (41AN38) in the Upper Neches River Basin of East Texas, assembled and edited by T. K. Perttula, D. B. Kelley, and R. A. Ricklis, pp. 145-320. Archeological Studies Program Report No. 129, Texas Department of Transportation, Environmental Affairs Division, Austin.

2016 Utility Ware Ceramic Metrics and Hasinai Caddo Archaeology in East Texas. Journal of Northeast Texas Archaeology 70:61-68. 
Perttula, T. K., L. L. Bush, L. Schniebs, T. Middlebrook, and P. S. Marceaux

2010 An Early Historic Caddo Farmstead at the Henry M. Site (41NA60) in Nacogdoches County, Texas. Stephen F. Austin State University Press, Nacogdoches.

Perttula, T. K., M. B. Trubitt, and J. S. Girard

2012 The Use of Shell-Tempered Pottery in the Caddo Area of the Southeastern United States. Southeastern Archaeology 30(2):242-267.

Story, D. A.

1990 Cultural History of the Native Americans. In The Archeology and Bioarcheology of the Gulf Coastal Plain, by D. A. Story, J. A Guy, B. A. Burnett, M. D. Freeman, J. C. Rose, D. G. Steele, B. W. Olive, and K. J. Reinhard, pp. 163-366. Research Series No. 38.2 Vols. Arkansas Archeological Survey, Fayetteville.

Suhm, D. A. and E. B. Jelks (editors)

1962 Handbook of Texas Archeology: Type Descriptions. Special Publication No. 1, Texas Archeological Society, and Bulletin No. 4, Texas Memorial Museum, Austin.

Turner, E. S., T. R. Hester, and R. L. McReynolds

2011 Stone Artifacts of Texas Indians. ${ }^{\text {rd }}$ Edition. Taylor Trade Publishing, Lanham, Maryland.

Varien, M. D.

1995 Analysis of the Ground, Battered, and Polished Stone Artifacts. . In The Deshazo Site, Nacogdoches County, Texas, Volume 2: Artifacts of Native Manufacture, edited by D. A. Story, pp. 13-32. Studies in Archeology 21. Texas Archeological Research Laboratory, The University of Texas at Austin.

Webb, C. H.

2000 Stone Points and Tools of Northwestern Louisiana. Special Publication No. 1, $2^{\text {nd }}$ edition. Louisiana Archeological Society, Lafayette. 